Portland State University

PDXScholar

2-2-1996

\title{
Alpine Soil Geomorphology: The Development and Characterization of Soil in the Alpine-Subalpine Zone of the Wallowa Mountains, Oregon
}

Charles Edward Allen

Portland State University

Follow this and additional works at: https://pdxscholar.library.pdx.edu/open_access_etds

Part of the Geography Commons

Let us know how access to this document benefits you.

\section{Recommended Citation}

Allen, Charles Edward, "Alpine Soil Geomorphology: The Development and Characterization of Soil in the Alpine-Subalpine Zone of the Wallowa Mountains, Oregon" (1996). Dissertations and Theses. Paper 5217. https://doi.org/10.15760/etd.7093

This Thesis is brought to you for free and open access. It has been accepted for inclusion in Dissertations and Theses by an authorized administrator of PDXScholar. Please contact us if we can make this document more accessible: pdxscholar@pdx.edu. 
THESIS APPROVAL

The abstract and thesis of Charles Edward Allen for the Master of Science in Geography were presented October 9, 1995, and accepted by the thesis committee and the department.

COMMITTEE APPROVALS:

DEPARTMENT APPROVAL:

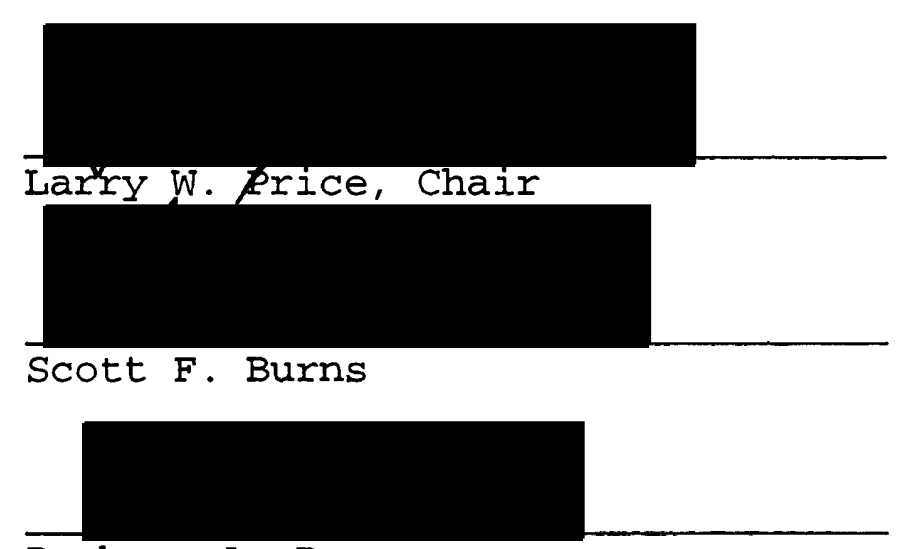

Barbara A. Brower

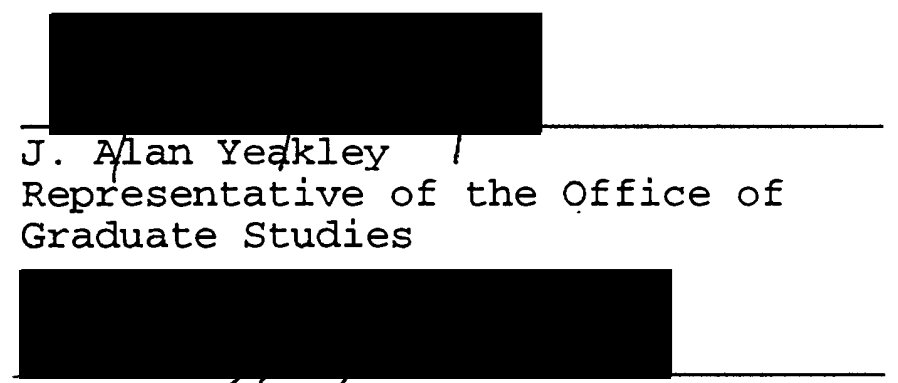

Daniel 1 . Johnson, Chair

Department of Geography

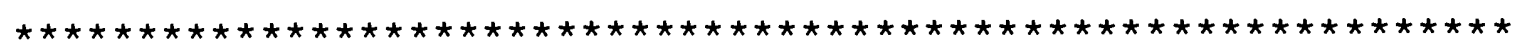
ACCEPTED FOR PORTLAND STATE UNIVERSITY BY THE LIBRARY

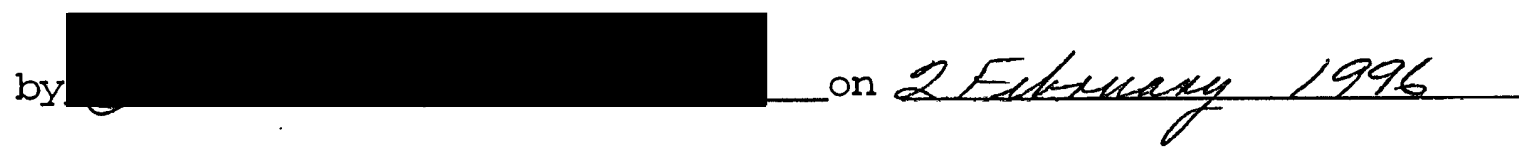




\section{ABSTRACT}

An abstract of the thesis of Charles Edward Allen for the Master of Science in Geography presented October 9, 1995.

Title: Alpine Soil Geomorphology: The Development and Characterization of Soil in the Alpine-Subalpine Zone of the Wallowa Mountains, Oregon.

Alpine soils are young, poorly developed soils that occur above treeline. This study investigates soils located in the alpine-subalpine zone of the Wallowa Mountains, northeast Oregon. Parent material, topography, and vegetation are the most influential pedogenic factors in the high alpine landscape of the Wallowas. Soil samples were collected from the Eagle Cap Wilderness Area of the Wallowas at three mountain locations: Eagle Cap, Sacajawea, and Matterhorn. Catenas were studied in the Windblown and Minimum snowcover zones to examine different pedogenic factors, according to the Synthetic Alpine Slope model.

Field and laboratory testing characterized the alpine soils as predominantly loamy-sands with weak structural development. The 1:1 water $\mathrm{pH}$ values range from 6.5 to 7.3 , and the soil hues are 10YR and 2.5Y in color. Soil classification characterized Eagle Cap soils as Andisols: 
Lithic and Typic Haplocryands. The Matterhorn and Sacajawea residuum was not classified.

Parent material influence on soil development was more noticeable on granodiorite than basalt, reflecting the propensity of granodiorite to weather rapidly. Marble and shale sites lacked soil development. All the soils exhibited eolian influence, determined from silt mineralogy results. While this component did not dominate the soils as in other alpine areas, its presence was proven by quartz and feldspars in soils developed on marble and calcite in soils developed on granodiorite. Sodium fluoride (NaF) $\mathrm{pH}$ tests indicate that there is also a high aluminum content in the alpine soils, probably due to influx of Mazama volcanic ash.

Krummholz and alpine turf increase the organic content of the soil, although soils beneath krummholz were not as deep. This is partially due to decreased snowcover, subsequent lack of moisture, and different parent material. All soils show a decrease in organic carbon with depth indicating that bioturbation was either low, or the soil recovered from the disturbance rapidly. Organocutans found on the bottom of rocks in the B horizon illustrate organic translocation. The increase in $\mathrm{pH}$ with depth shows the influence of surficial organic matter, translocated dusts, and ash. Nunatak and landmass influence on soil development was undetermined. 
ALPINE SOIL GEOMORPHOLOGY: THE DEVELOPMENT

AND CHARACTERIZATION OF SOIL IN THE ALPINE-SUBALPINE ZONE

OF THE WALLOWA MOUNTAINS, OREGON

by

CHARLES EDWARD ALLEN

A thesis submitted in partial fulfillment of the requirements for the degree of

\author{
MASTER OF SCIENCE \\ in \\ GEOGRAPHY
}

Portland State University

1996 


\section{ACKNOWLEDGMENTS}

I'd like to thank many people whose contributions and support made this thesis possible. Notably, the three mountain experts, who as my committee provided invaluable insight into my topic of research. Larry Price, who introduced me to the Wallowas, read various drafts and made many bibliographic suggestions. Scott Burns, whose enthusiasm, especially whilst in the field, and extensive knowledge on alpine soils were greatly appreciated. Barbara Brower provided encouragement, editorial advice, and a different perspective on alpine environments. I'd also like to thank the Graduate School representative, Alan Yeakley, for his editorial comments and interest in soils.

Thank you to Wallowa experts, John Allen, Timothy Bliss, Bob Carson, and Bob ottersburg for their time and insights concerning the mountains. My appreciation goes to Reka Gabor for conducting the silt mineralogy analysis, and to carolyn Perry for all her help.

I am indebted to the Himalayan Research Bulletin, who loaned the use of their computer, the Geology Department who let me use their soils and Sedimentology Laboratories, and the Oregon Soil Scientist Society Scholarship, which provided much-needed support for laboratory analysis. 
Finally, I'd like to thank my family for their wholehearted support. Dawn Coppin has provided encouragement, love, and invaluable editorial assistance. The Portland state University Mountain Field Camp participants (Summer 1993) must be thanked, especially Rick Cvarak and Mark Mahler for their friendship and intellectual asides. 
TABLE OF CONTENTS

PAGE

ACKNOWLEDGEMENTS $\ldots \ldots \ldots \ldots \ldots \ldots \ldots \ldots \ldots \ldots \ldots \ldots \ldots$

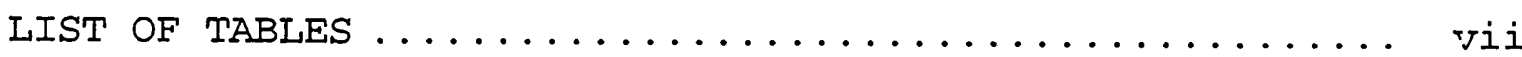

LIST OF FIGURES ...................... viii

CHAPTER

I INTRODUCTION $\ldots \ldots \ldots \ldots \ldots \ldots \ldots \ldots \ldots \ldots \ldots \ldots$

II $\quad S T U D Y$ AREA $\ldots \ldots \ldots \ldots \ldots \ldots \ldots \ldots \ldots \ldots \ldots \ldots \ldots \ldots \ldots$

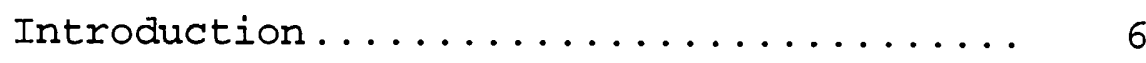

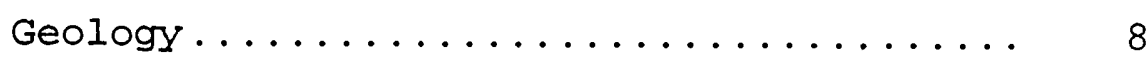

Quaternary History................. 10

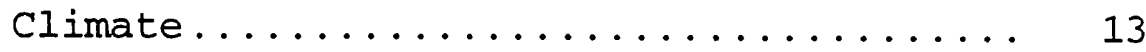

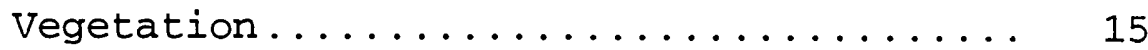

III SOIL GEOMORPHOLOGY .................... 19

Introduction.................... 19

Soil Formation................... 20

Alpine Soils.................... 24

Previous Studies

Soil Forming Factors............... 30

Lithologic

Climatic

Biologic

Topographic 
IV THEORETICAI CONCEPTS

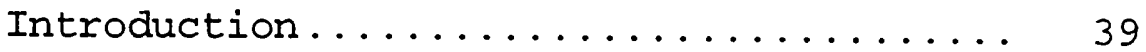

Spatial Constructs.............. 40

Soil Catenas

Temporal Constructs.............. 42

The Soil Chronosequence

V METHODOLOGY ....................... 44

Selection of study Sites............. 44

Field Methods................. 46

Laboratory Analysis............... 50

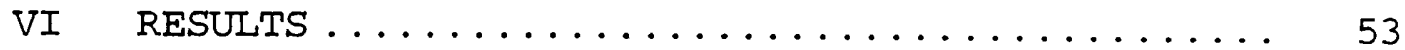

Field Soil Properties.............. 53

Eagle Cap Catena

Matterhorn Catena

Sacajawea Summit

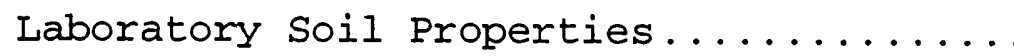

Particle Size Analysis

Soil pH

Soil Organics

Silt Mineralogy

Classification

VII $\operatorname{DISCUSSION\ldots \ldots \ldots \ldots \ldots \ldots \ldots \ldots \ldots \ldots \ldots \ldots \ldots \ldots \ldots \ldots }$

Field and Laboratory Results......... 100

Nunatak Hypothesis................ 103

VIII CONCLUSIONS ....................... 107

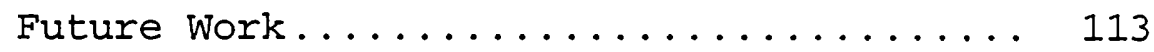

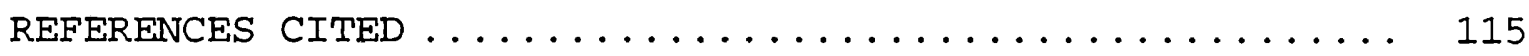




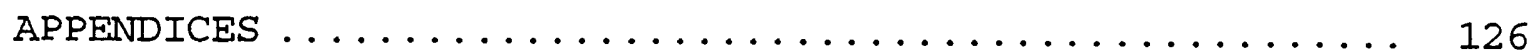

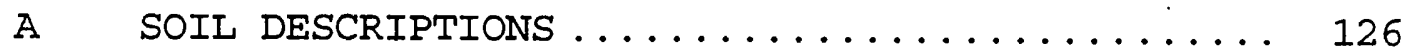

B CUMULATIVE FREQUENCY CURVES ............. 135

C SODIUM FLUORIDE (NaF) TEST FOR ALLOPHANE . . ... 154

D SILT MINERALOGY PROCEDURE ............. 156 


\section{LIST OF TABLES}

I sediment Characterization ............... 80

II sorting According to Standard Deviation and

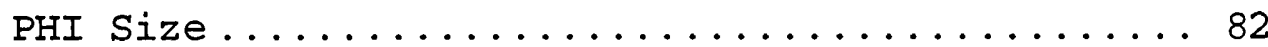

III Standard Deviation and Sorting ............ 82

IV Soil pH Results $\left(1: 1\right.$ water and $\left.2: 1 \mathrm{CaCl}_{2}\right) \ldots \ldots 7$

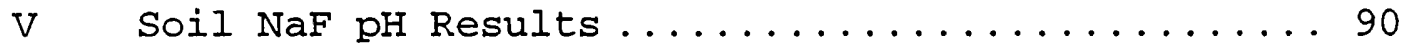

VI Soil Organic Content .................. 94 


\section{LIST OF FIGURES}

1. Generalized Alpine-Subalpine Zone ........... 2

2. Location of the Wallowa Mountains, Northeast

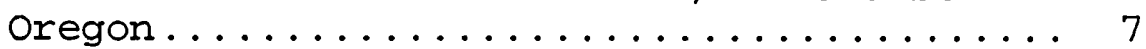

3. Generalized Surficial Geology of the Eagle Cap Wilderness Area, Wallowa Mountains....... 11

4. Glacial Evidence: U-Shape of the East Fork of the Lostine River Valley............. 12

5. Lake Basin Managment Area ............... 14

6. Whitebark pine seedling and growth ......... 18

7. Hans Jenny's state Factors ............... 21

8. Synthetic Alpine Slope (SAS) Model .......... 26

9. Schematic Alpine Soil Catena .............. 27

10. Eagle Cap wilderness .................. 45

11. Lake Basin Study Area ................. 47

12. Eagle Cap Catena Cross-Section ............. 48

13. Matterhorn-Sacajawea Cross-Section ........... 48

14. Eagle Cap ........................ 54

15. Soil Profile $5 E C \ldots \ldots \ldots \ldots \ldots \ldots \ldots \ldots \ldots$

16. Eagle Cap Sumnit site of Soil Pit 1EC ........56

17. Soil Profile 1EC .................... 56

18. Eagle Cap site of Soil Pit 2EC ............. 59

19. Soil Profile 2 EC ....................... 59

20. Eagle Cap Site of Soil Pit 3EC .............60 
21. Soil Profile $3 E C \ldots \ldots \ldots \ldots \ldots \ldots \ldots \ldots \ldots 6$

22. Eagle Cap Site of Soil Pit 4 EC ............66 63

23. Soil Profile $4 E C \ldots \ldots \ldots \ldots \ldots \ldots \ldots \ldots \ldots$

24. The Matterhorn $\ldots \ldots \ldots \ldots \ldots \ldots \ldots \ldots \ldots 67$

25. Matterhorn Summit Site of Soil Pit $1 \mathrm{MH} \ldots \ldots \ldots 69$

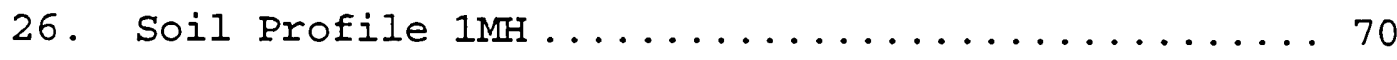

27. Matterhorn Site of Soil Pit $2 \mathrm{MH} \ldots \ldots \ldots \ldots \ldots 72$

28. Soil Profile $2 \mathrm{MH} \ldots \ldots \ldots \ldots \ldots \ldots \ldots \ldots \ldots \ldots \ldots$

29. Sacajawea ........................... 75

30. Sacajawea Summit Site of Soil Pit SA....... 76

31. Soil Profile SA.................... 77

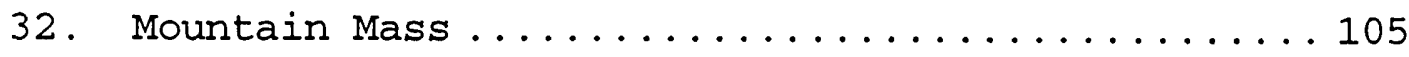

33. Extent of Treeline on Eagle Cap's northwest slope........................ 109

34. Silt Mineralogy Eagle Cap (1EC2) ........... 158

35. Silt Mineralogy Matterhorn (1MH2) ......... 159 


\section{CHAPTER I}

\section{INTRODUCTION}

This study examines soil development in the alpinesubalpine zone of the Wallowa Mountains in northeast Oregon and characterizes the soils according to soil-forming factors. A problem in studying alpine soils is deciding exactly what constitutes this alpine-subalpine zone. In most cases the alpine zone is considered to be the treeless area beyond the treeline (Goudie et al. 1994). The subalpine zone is the spruce-fir forest below the treeline where trees grow upright. The Wallowa Mountains have all the qualities of an alpine tundra environment, but treeline is just barely reached (Franklin and Dyrness 1988). For the purpose of this research, alpine soils are classified as those that occur beyond treeline (also referred to as the timberline) (Figure 1).

The alpine-subalpine zone is a region of transition from forest to alpine vegetation (Ives and Barry 1974) and consists of patches of alpine tundra and krummholz tree islands. Therefore, it provides a contrast in environmental settings to study the development and distribution of mountain soils. The forest-tundra ecotone (FTE) is another name for this transitional zone that overlaps the 


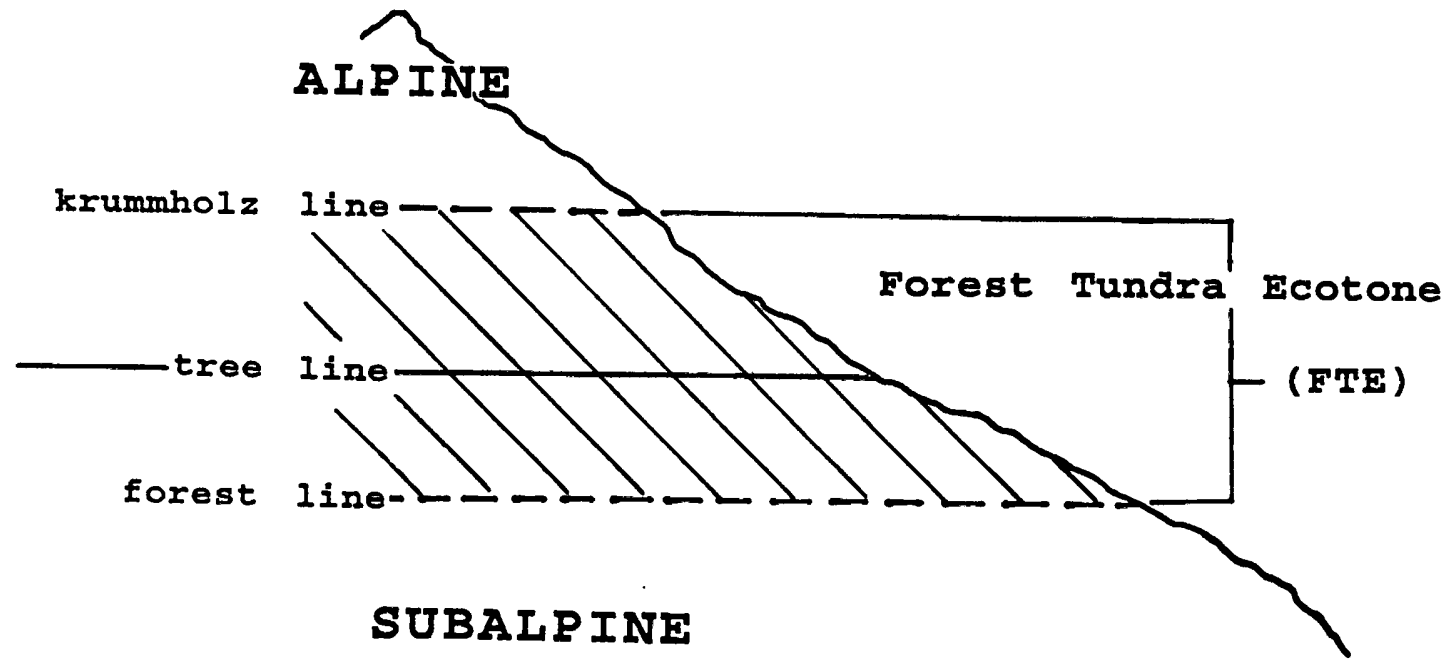

Figure 1. Generalized Alpine-Subalpine Zone. The ForestTundra Ecotone, the shaded area between forest line and krummholz line, is synonymous with the Alpine-subalpine zone. (Adapted from Löve 1970 and Ives and Barry 1974) 
alpine-subalpine zone (Love 1970: 58). In the Wallowa Mountains, the alpine-subalpine zone applies to the highest mountain summits, such as Eagle Cap, the Matterhorn, and Sacajawea. These three areas were selected as study sites.

The Wallowas are part of the Blue Mountain physiographic province (orr et al. 1992). They contain many of Oregon's highest peaks (17 are over 2,900 meters) and constitute some of the most picturesque mountains in the state. The Wallowas also offer a unique natural laboratory for studying alpine phenomena. The localized interactions of soil-forming factors, the influence of the region's glacial history, age, and size of the mountain range, the influx of Mount Mazama (7,000 BP) volcanic ash, eolian sediments, and an active geologic past make the Wallowas an ideal setting in which to study the development and characterization of alpine soils. The aims and objectives of this study are to characterize the alpine soils according to the soil-forming factors and determine how developed they are. The hypothesis of this study is that in the alpine landscape of the Wallowas, the major pedogenic factors are biology, parent material (inclusive of eolian sediments), and topography. Mountain mass, snow cover (microclimatology), and time play a minor role in soil development in the Wallowas.

While soil geomorphology is a rapidly advancing field of study (Gerrard 1992), few studies have focused on mountain regions, which is surprising given the increasing geographic 
research in mountain areas. Studies focused on mountains in the United States have been carried out primarily in the Rocky Mountains of Colorado, Montana and Wyoming (Birkeland 1990). However, few of these alpine studies have focused on soil-geomorphic processes, except when related to glacial and/or periglacial phenomena, such as moraines, cirque deposits, permafrost or patterned ground (Berry 1987; Birkeland et al. 1987; Bockheim and Burns 1991; Hall and Shroba 1993; Birkeland 1994; Dahms 1994).

A soil profile develops through the interaction of certain environmental factors. These factors are: biology, chronology, climate, lithology, and topography (Jenny 1941; Ritter et al. 1995). Epipedons, horizons, and structure are features that exemplify the developed soil profile. These features typically take a long time to develop in mountains because of extreme environmental conditions which means alpine soils are generally considered young. Other localized variables, such as ash, eolian sediments, landmass, and microfeatures, tend to speed up or slow down the rate of soil formation.

This study describes how soil development in the alpinesubalpine zone relates to environmental setting. The different geologic units, slope and aspect, micro-climate and changing vegetation all provide information concerning development and character of the soil. Eolian sediments, fire history, microtopography, snow cover, volcanic ash, the 
impact of burrowing animals and larger mammals such as mountain goats, and finally, human impact, are all important variables. To determine the influence of these variables, study sites were selected according to differing slope aspect, gradient, lithology, topography, and vegetation on an alpine catena. Cut-banks on the side of the hiking trail were examined to determine whether the soil exhibited characteristics representative of the area. This was followed by soil sampling to discover which was the most influential soil-forming factor.

The Synthetic Alpine Slope model (Burns and Tonkin 1982) provides a theoretical framework for the study, as well as a basis for comparison with other mountain soil research. The narrow alpine zone in the Wallowas means that Windblown (WB) and Minimum Snowcover (MSC) sites are the only available areas to investigate alpine soil development.

In an effort to gain a holistic perspective, the methodology for this research coupled laboratory testing with field investigation. The results of the study characterize those soils sampled, and determine the extent of development of the alpine soils in the wallowas according to the interaction of soil-forming factors at each site. 
CHAPTER II

STUDY AREA

INTRODUCTION

The rugged, dome-shaped, radially-arained Wallowa Mountains lie at the intersection of three northeastern Oregon counties: Baker, Union, and Wallowa (Figure 2). As part of the Blue Mountain physiographic region (Orr et al. 1992), they are the site of some of Oregon's oldest geology, textbook glacial geomorphology, and highest mountain peaks. Their interesting alpine geography comes from a turbulent past which includes structural deformation, volcanism, and Quaternary glaciation.

The earliest scientific studies in the Wallowa Mountains relate to the discovery of gold and other valuable minerals (Lindgren 1901). As prospecting increased and mining influenced the economy, the need for research grew. Some of the state's best early earth science work is visible in influential papers by warren Dupre Smith (1918), J. C. Stovall (1929), and Clyde Ross (1938). One of the most often cited texts is The Geology and Physiography of the Northern Wallowa Mountains, oregon (Smith et al. 1941). This study provides a synopsis of much of the early geologic work in the area. Since then, earth science research has continued, 

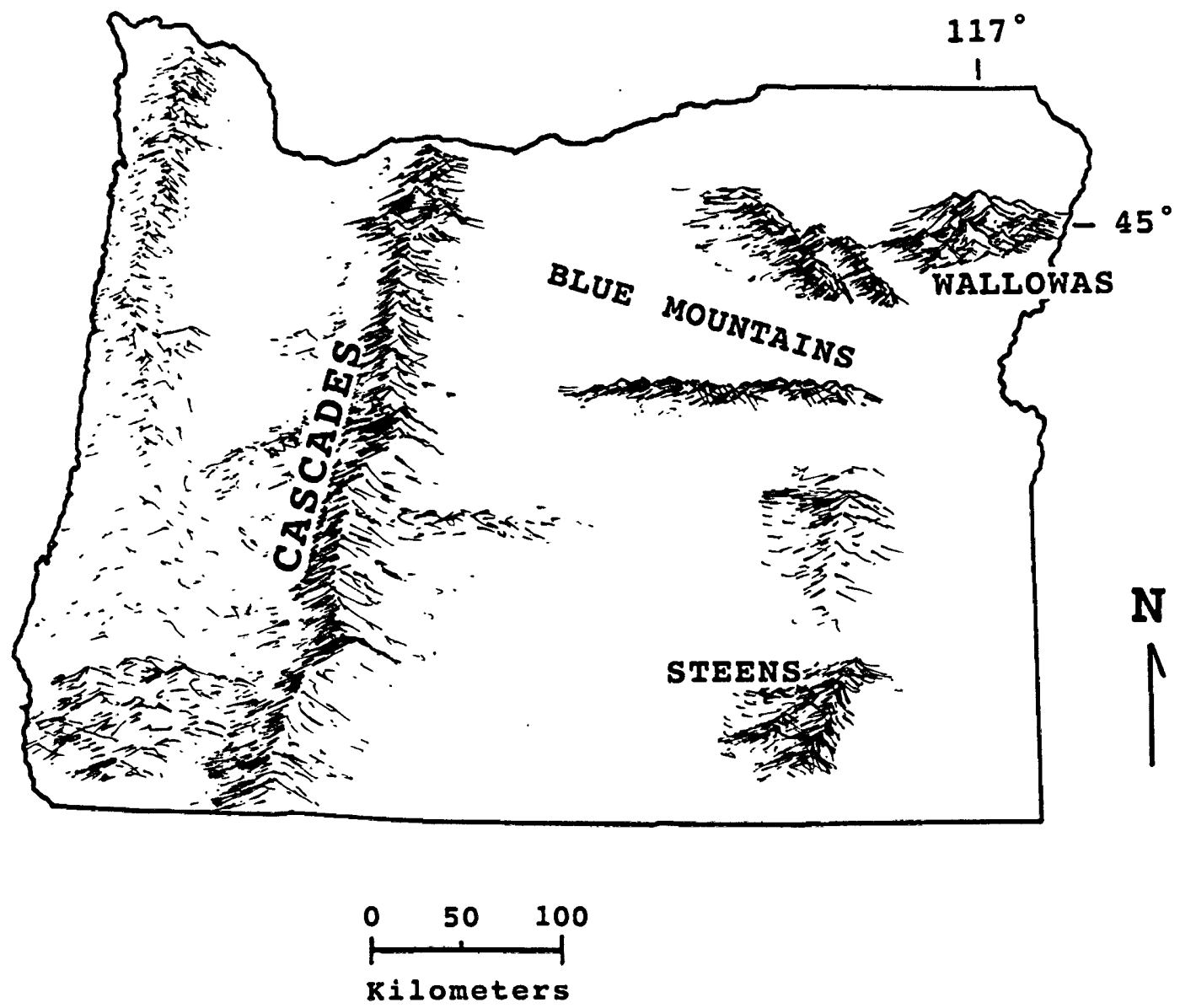

Figure 2. Location of the Wallowa Mountains, northeast Oregon. 
predominantly in the form of theses and dissertations. Some of the more recent investigations have discussed vegetation (Mason 1975; Cole 1982; Price 1994), glaciation (Crandell 1965; Bentley 1974; Kiver 1974), geology and mineralogy (Kiilsgaard et al. 1984; Taubeneck 1987; Follo 1994; Carson et a.1. 1995).

\section{GEOLOGY}

The Wallowa Mountains are thought once to have been a barrier island system situated off the coast of present-day North America (McKee 1972). Subsequent plate movement, tectonism, and glaciation have modified them since. This sequence of events began about 230 million years ago, toward the end of the Paleozoic era. The area experienced increased volcanism, and the islands began their collision course toward the Pacific plate. Permo-Triassic volcanic sediments deposited on and around the archipelago now underlie an intricate knit of sedimentary, metamorphic and igneous rocks that make up the visible part of the Wallowa Mountains.

The gradual mountain construction occurred about the same time as the Hercynian orogeny, about 230 million years ago, which was responsible for the creation of the European Alps (Orr et al. 1992). After subsequent folding and faulting, the islands were accreted to the North American plate as a series of "exotic" terranes. The present inland position of the Wallowas relates to the gradual rotation of 
the North American continent and further accretion of other terranes, such as the Izee and Baker terranes (Orr et al. 1992). One scenario postulates four episodes of deformation. These are pre-batholith accretion, batholith emplacement, basaltic extrusion, and finally normal faulting (Neal 1973; Weis et al. 1976).

Toward the end of the Triassic, a series of large igneous intrusions, related to the Idaho batholith, further deformed the accreted terranes and metamorphosed the limestones and muds into marble and slate. The remnants of the terranes are visible as two major examples of metamorphic outcrops. The Martin Bridge Formation, a limestone formation deposited in a shallow ocean environment, is by far the most widespread sedimentary deposit in the Wallowas (Follo 1994). The other marine sediment is the Hurwal Formation, composed of calcareous argillite interbedded sandstones (Follo 1994). This provides an intriguing contrast of parent materials, from which the soils have developed.

Eventually, the intrusions cooled to form gneissic granodiorite and/or tonalite (Taubeneck 1987). The huge granodiorite batholith which is now visible in places, such as the central peak, Eagle Cap, was intruded toward the end of the Late Cretaceous, about 120 million years ago (Nolf 1966). The batholith emplacement was accompanied by a series of mafic dikes, which visibly transect the Mountain Range. In addition, there are younger feeder dikes related to the 
Columbia River Basalts (Taubeneck 1987). These formed 17 to 6 million years ago as lava flowed across eastern oregon and covered all but the highest peaks. Many of these layers have since been eroded and are visible now only as small outcrops (Neal 1973) (Figure 3).

\section{QUATERNARY HISTORY}

During the Pleistocene, the Wallowas were part of the Cordilleran Glacier Complex (Flint 1971), covered with an ice cap that left the highest peaks as nunataks above the ice field (Crandell 1965; Allen 1975). The glaciers carved out the huge U-shaped valleys visible today (Figure 4 ) and deposited the moraines found at the margins of the mountains. The resulting steep topography creates instability, often leading to debris flows and snow avalanches. These mass wasting features affect both the soil distribution and vegetation.

There is evidence that soils developed during the Pleistocene interglacial period. The Wallowa Lake moraines exhibit soil development in-between stages of glaciation, and this has been used to support the argument for three periods of Wallowa glaciation during the Pleistocene (Crandell 1965: 350; Crandell 1967). 


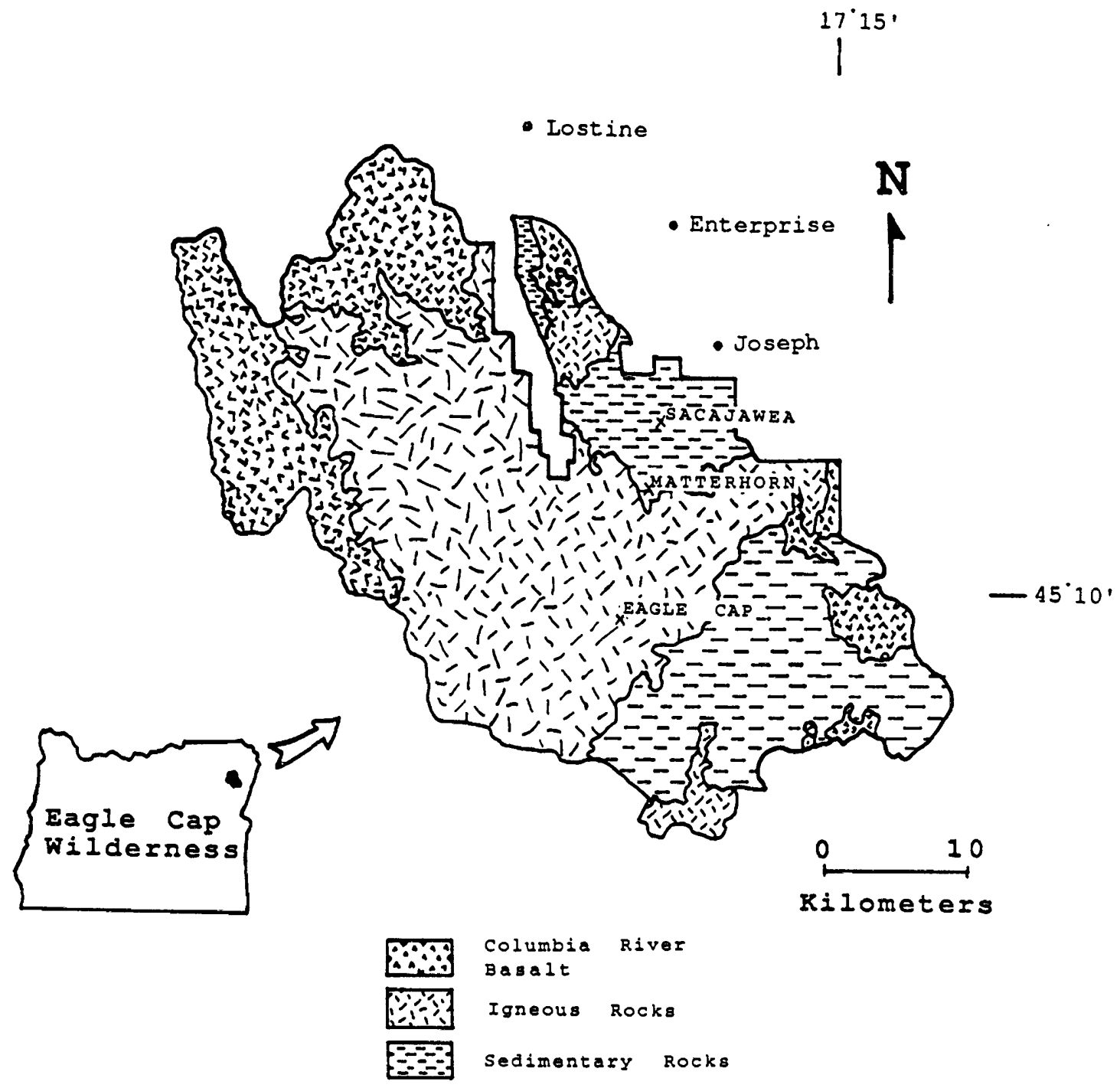

Figure 3. Generalized surficial geology of the Eagle Cap Wilderness Area, Wallowa Mountains. Towns provided for geographic reference. (Adapted from Cole 1982 and Killsgaard and Tuchek 1984) 


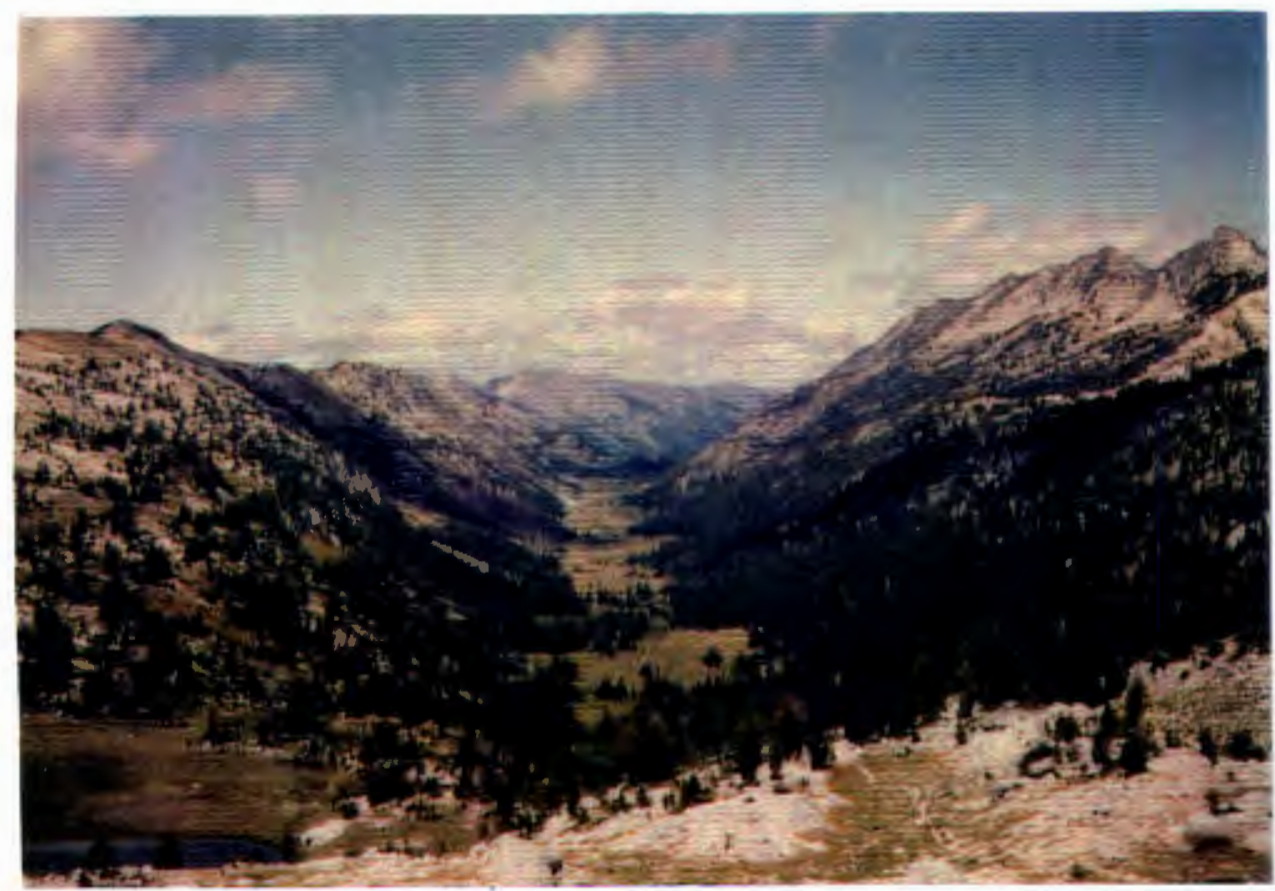

Figure 4. Glacial Evidence: U-shape of the East Fork of the Lostine River Valley. Photograph taken looking north from Horton Pass, located on the northwest slope of Eagle Cap. 
Glaciation of the mountains continued into the Holocene. In examining lichen (Rhizocarpum geographicum) distribution, Kiver (1974: 187) was able to determine three additional glacial advances in the Holocene (Eagle Cap 0-600 BP, Prospect Lake 950-1900 BP, Glacier Lake 6600-12000 BP). While the very poor to no soil development in the Eagle Cap cirque deposits is attributed to these glacial advances (Kiver 1974: 177), the ice cover should not have hindered the alpine soil development above the ice on the nunataks.

\section{CLIMATE}

Oregon's climate is controlled by topography and the maritime influence of the Pacific Ocean (Johnson and Dart 1982). The Wallowa Mountains are located to the lee of the Cascades and so have aspects of both maritime and continental climates. Their climate is generally classified as moderate continental, making them similar to the Rocky Mountains (Price 1978).

Precipitation in the Lake Basin (Figure 5) averages about 60 centimeters a year, and temperature ranges from a mean January temperature of $-7^{\circ} \mathrm{C}$ to $28^{\circ} \mathrm{C}$ mean July temperature (Franklin and Dyrness 1988). An extensive snowpack develops and covers peaks with snow year-round. This is especially apparent on leeside sites where snow gathers. The continental climate of the Wallowas ensures that there is often a high 


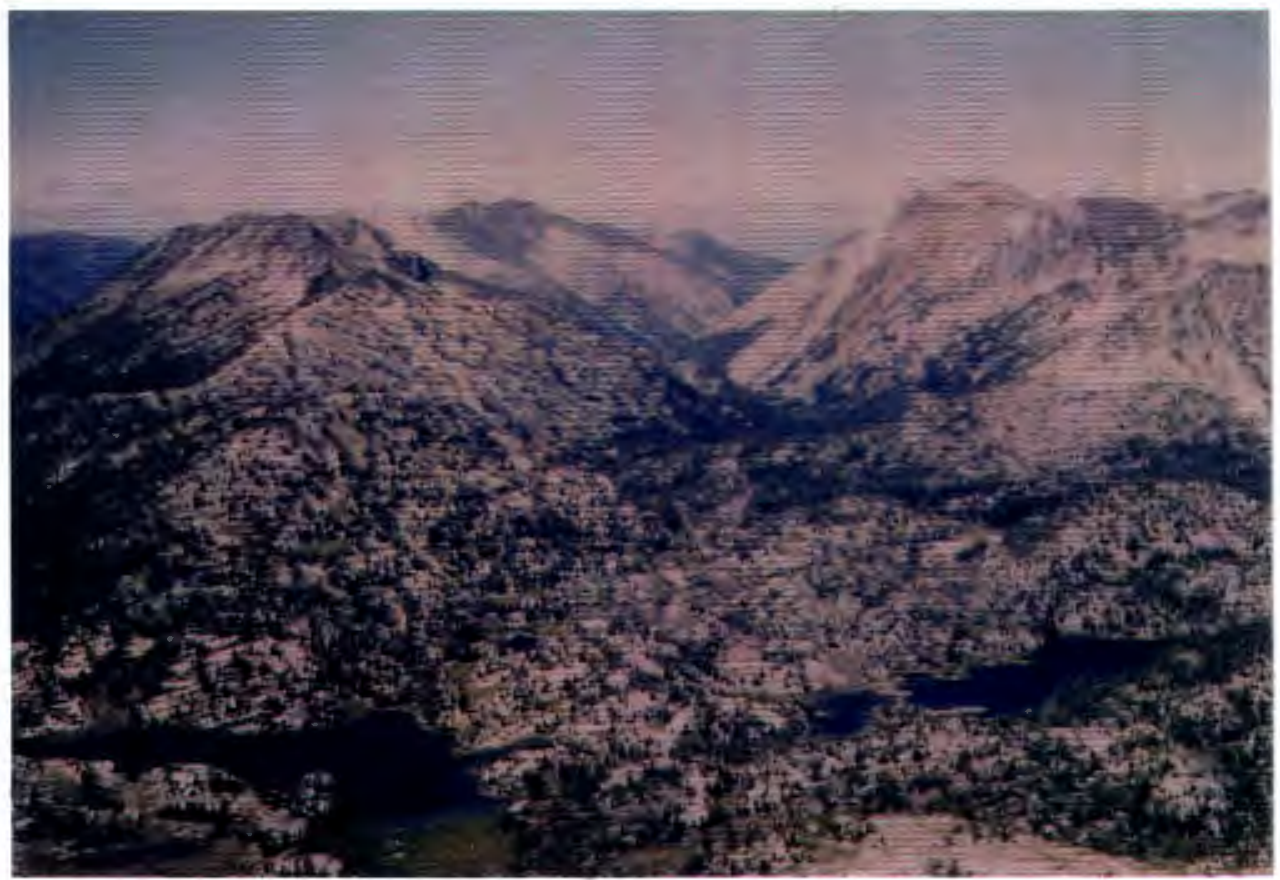

Figure 5. Lake Basin Management Area. Photograph taken looking north from Eagle Cap. Matterhorn is the highest peak situated to the right of center of the picture. 
snow accumulation in the Lake Basin. However, the windier peaks and ridges are often bare of snow. These factors affect soil development.

\section{VEGETATION}

Tree species in the upper reaches of the wallowas consist predominantly of the subalpine fir (Abies lasiocarpa), Engelmann spruce (Picea engelmanii), and whitebark pine (Pinus albicaulis). Other species of trees include limber pine (Pinus flexilis) often found on the calcium carbonate rocks, and quaking aspen (Populus tremuloides) where there is an increased soil moisture (Mason 1975; Cole 1982).

The base of the subalpine zone begins at approximately 2,400 meters (north-facing slopes), lowering to 2,100 meters on calcareous rocks (Cole 1982: 24). Forest line can be drawn at approximately 2,700 meters (Price 1978: 471), with an upper krummholz line extending to the summits, especially on Eagle Cap, where clumping of trees occurs. This is related to both topography and climate. Valleys may be lacking trees owing to the late-laying snow as well as cold air drainage. Microtopography effects such as ledges and hollows provide shelter and warmth that cause trees to clump in these areas. Climatic effects are visible throughout the Wallowas, where treeline is lower on the more shaded north-facing slopes. 
According to Arno (1984: 213), the Wallowas are the only part of the Blue Mountains that have a sizable alpine treeline. Krummholz occurs in windy areas and sites related to the distribution of the snow cover. Arno (1984) classifies the vegetation as being similar and related to the northern Rocky Mountains, but he mentions that the Wallowas differ in so far as they belong to the Intermountain Range and exhibit lower precipitation, snow, and cloud cover than the central and Northern Rockies. However, the Wallowas have a fairly heavy snow accumulation. Franklin and Dyrness (1988: 249), concur with Arno, stating the "..elevations [are] sufficient to develop true timberline conditions." The treeline is higher on south-facing slopes; on northern slopes the krummholz line is made up predominantly of whitebark pine. The Wallowas provide the necessary environmental criteria for research into alpine soil development and distribution.

Plant-soil (edaphic) studies in the past have concentrated on the subalpine green fescue grassland that was once typical of the Wallowa Mountains. This was heavily affected by sheep grazing but has been gradually recovering (Arno 1984: 213). Many subsequent soil studies in the Wallowas relate to the grassland, its depletion, and revegetation (Sampson 1909; Pickford and Reid 1942; Strickler 1961; Cole 1982). Fewer studies have examined the circumstances of treeline, meadow expansion, and soil degradation at higher elevations. One study by Mason (1975) 
does suggest that in areas of higher elevation, the soils are generally shallower and lose moisture quicker. These factors would make the soils more susceptible to erosion, especially in a windy environment with considerable back country use. The serious question concerning human impact on the landscape has not been extensively researched. Soils in the Wallowa Mountains have suffered erosion as shown by the studies by strickler (1961) and cole (1981). The soil depletion and vegetation change caused by sheep certainly affected the distribution and development of the Wallowa alpine soils at lower elevations (Figure 6). Even though grazing has been restricted, and regulations have been designed to diminish the erosion rates, human recreational use has visibly increased. 


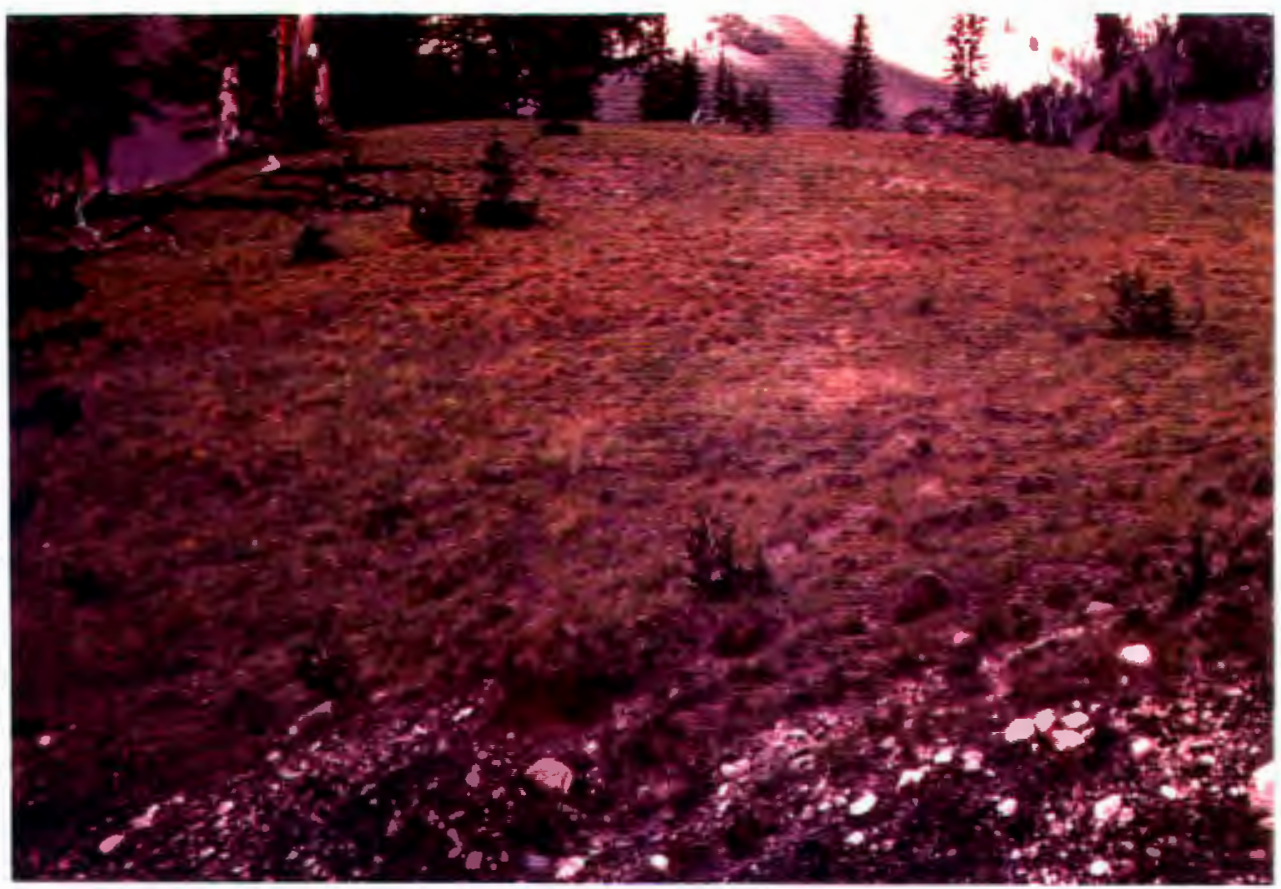

Eigure 6. Whitebark pine seedling and growth. Expansion and revegetation of grasses since grazing restriction. (E.H. Reid, courtesy of Larry W. Price) 
CHAPTER III

\section{SOIL GEOMORPHOLOGY}

\section{INTRODUCTION}

Soil science includes both edaphic (plant-soil relations) and pedologic (soil weathered from geologic deposits) studies. Soil geomorphology is the merging of soil science with landform studies and their subsequent interrelationships (Gerrard 1992: 2). It deals with soil forming processes, the spatial and temporal attributes of a soil, its distribution, and the age of surficial deposits. Soil geomorphology studies are often approached within the context of catenas and chronosequences. These help determine particular soil-landscape relationships and are widely used in soil geomorphology research.

The increase in the number of soil geomorphology studies during the last two decades has resulted in several textbooks, including Soils and Geomorphology (Birkeland 1984), Geomorphology and Soils (Richards et al. 1985), Soils and Landscape Evolution (Kneupfer and McFadden 1990), and Soil Geomorphology (Gerrard 1992). The interdisciplinary nature of soil geomorphology is stressed in all of these, with studies conducted by geographers, geologists, hydrologists, and soil scientists. Moreover, the texts stress 
the importance of soil development and distribution and how soils may help in understanding and explaining the dynamism of the environment.

\section{Soil Formation}

The Russian soil scientist, Dokuchayev, is considered to be the first person to document the connection between soil and environmental (soil-forming) factors. His work in the latter part of the 19th century recognized the strong relationship of soil to the environment and how the soil varied according to climate, geology, and vegetation. A similar interest developed in the United States through the work of E. W. Hilgard (1911). Since he emphasized geology, pedologic soil studies favored using geologic units to map soil distribution for some time afterward.

Hans Jenny (1941) synthesized many of the early ideas and formulated an equation that forms the basis for soil geomorphology studies today (Amundsen et al. 1994). The soil forming factors Jenny (1941) defined are climate, vegetation and organisms, parent material, topography and time, plus numerous other local variables independent of the global system (Figure 7).

$$
S=f(c l, o, r, p, t, \ldots,)
$$


INFLUX
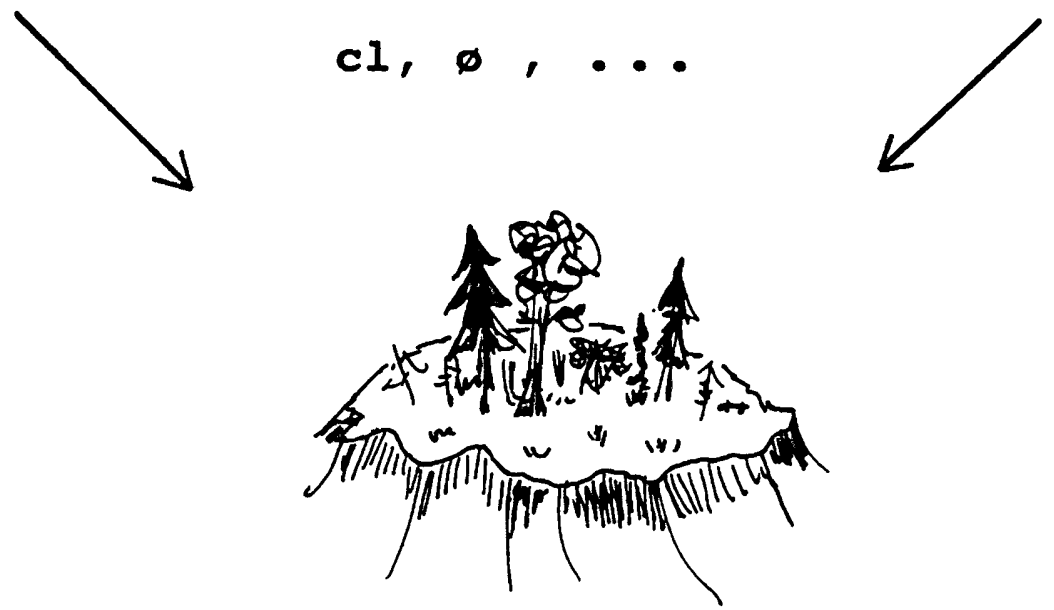

Initial state

$r, p$
Time, +

(age)

Eigure 7. Hans Jenny's State Factors. (Jenny 1980) Diagram of

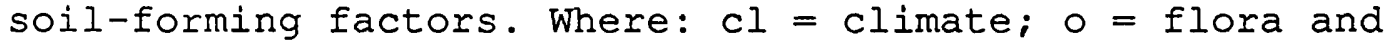
fauna; $r=$ topography and water table; $p=$ parent material; and $\ldots=\operatorname{dotfactors~(local).~}$ 
According to this equation (1), soil formation (S) is a function of (f) the interaction of the climatic (cl), biotic (o), topographic ( $r$ ), lithologic (p), and chronologic ( $t$ ) factors (Jenny 1941). By leaving the equation open-ended (..), Jenny permitted inclusion of additional, local variables.

Further research into the soil forming sequence by Jenny (1961) concluded that certain factors are more influential than others, and the extent of soil development depends on the particular locality. Jenny adapted his previous soil forming equation and adjusted the model to accept the notion that one factor might be more influential than the others (Jenny 1961: 387).

$$
\begin{aligned}
& S=f(c l, 0, r, p, t, \ldots, c l \text { climofunction/climosequence } \\
& S=f(0, c l, r, p, t, \ldots,) \text { biofunction/biosequence } \\
& S=f(x, c l, 0, p, t, \ldots,) \text { topofunction/toposequence } \\
& S=f(p, c l, o, r, t, \ldots,) \text { lithofunction/lithosequence } \\
& S=f(t, c l, 0, r, p, \ldots, \text { chronofunction/chronosequence } \\
& S=f(\ldots, c l, 0, r, p, t) \text { dotfunction/dotsequence }
\end{aligned}
$$

In each case, one of the factors (the bold letters) is the most influential in a particular setting. The other variables are of lesser importance in soil development. Furthermore, the equation mentions the influence of the micro-environmental factors, such as transported (allochtonous) materials and allocates them as dotfunctions. Therefore, the dotsequence considers the most important soil forming element to be the local variables in this particular 
equation. These are expected to be highly significant in the Wallowa Mountains.

The formula adopted in this thesis is the steady state factor equation, a modification proposed by Jenny (1980).

$$
l, v, a, s=f(c l)_{0, r, p, t} \ldots \text { climofunction }
$$

In this equation (8), the environment (1), interrelates with vegetation ( $v$ ), animals (a), and soil development(s) which in turn are all affected by the main function and to a certain extent lesser functions. The example given portrays the changing factors as affected by climate (cl), and the other variables $(0, r, p, t, \ldots)$ have a lesser effect. This is an effective method for determining soil erosion, age of the landscape, changing environments, or geomorphic surfaces, throughout the world.

Soil forming factors are especially visible in mountainous areas, owing to the extremity of the alpine environment and subsequent lengthy process of soil development. Although some recent reinterpretations concerning soil formation, such as the Nonlinear Dynamical System (Phillips 1993) and the Evolution Model (Johnson and Watson-Stegner 1987) have been proposed, this paper examines the alpine soils in the Wallowas according to Jenny's "cl,o,r,p,t" model. This allows for scrutiny of the geographical variations that affect soil development and 
determine its attributes in a region relatively untouched by soil geomorphologists.

\section{ALPINE SOILS}

Alpine soils are soils located above timberline in mountain regions (Retzer 1974: 771). Site variables important in mountain areas include snow accumulation, snow melt, snow cover, eolian loess, elevation, timberline, and slope angle. Mountain soils are typically shallow, coarse-textured, and predominantly of mineral composition. The apparent lack of soil development is due to the extremity of the environment which retards chemical and biological processes. Consequently, alpine soils often show fairly close relationships with the underlying geology and the topography (Retzer 1974). Topography controls the soil moisture because snow generally accumulates on the leeside of slopes, the same place that silt, clay and eolian loess accumulate.

Some alpine soils exhibit greater development, especially where there is micro-environment influence or if the environment is older (Burns 1985). These soils are typified by the presence of thicker soil horizons, higher content of organic matter, and clay accumulation.

The location, or geomorphic province has an important relation to the development and distribution of the soil. This study deals with the Ridge-Top Tundra Province, specifically the Windblown (WB) and Minimal Snow Cover (MSC) 
zones (Figure 8). Local factors are examined in depth to discover how much effect they have on the development and distribution of the soils.

A generalized alpine soil profile consists of a thin A horizon in windblown sites that relates to the vegetation cover and may contain some intermixed eolian loess (Retzer 1965). Burns (1980) notes that alpine soils in moist sites and sites with winter snowcover have much thicker A horizons, generally over $15 \mathrm{~cm}$ in thickness. This often overlies a poorly developed, shallow, weak, cambic B horizon (Bw), that exhibits slight development in color and/or structure with little or no illuvial accumulation of material and/or weathered bedrock (Soil Survey Staff 1992). The Bw horizon classification signifies weak development and reflects the time it takes the soil to develop and the degree of permeability (Figure 9).

\section{Previous Studies}

Few early texts in the North American literature, mention the alpine environment and soil development to any great extent. However, in the last 20 years, the number of studies relating to alpine soil geomorphology has greatly increased. One reason for this is the use of soils as a tool in providing dates for Quaternary deposits, as well as increased research funding through organizations such as the 


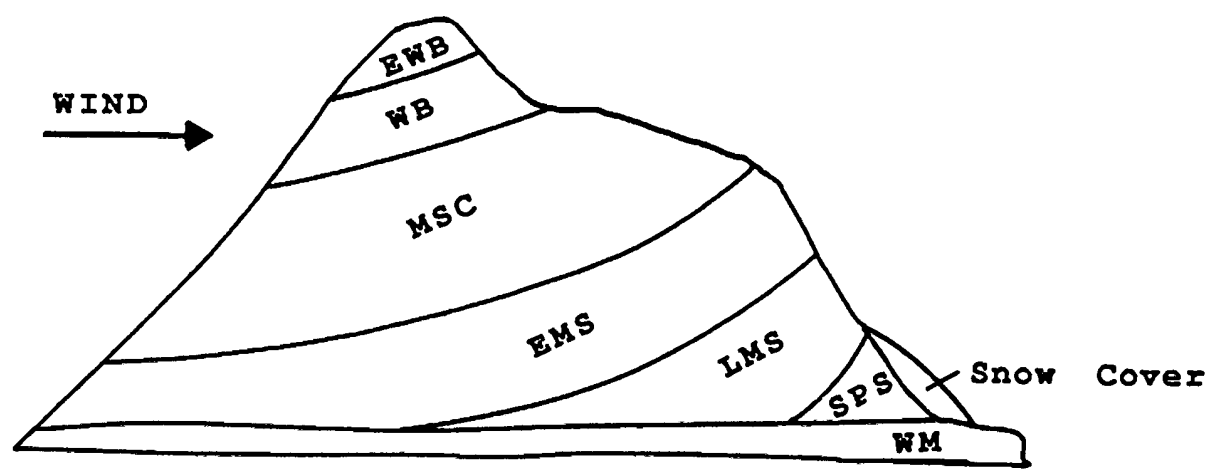

Figure 8. Synthetic Alpine Slope (SAS) Model. (Adapted from Burns and Tonkin 1982) Located in the Ridge-Top Tundra geomorphic province showing both windward and leeward sites. Where: $\mathrm{EWB}=$ Extremely Windblown; $\mathrm{WB}=$ Windblown; $\mathrm{MSC}=$ Minimum Snow Cover; EMS = Early Melting Snow; LMS = Late Melting Snow; SPS = Semipermanent Snowbank; and $\mathrm{WM}=$ Wet Meadow. 


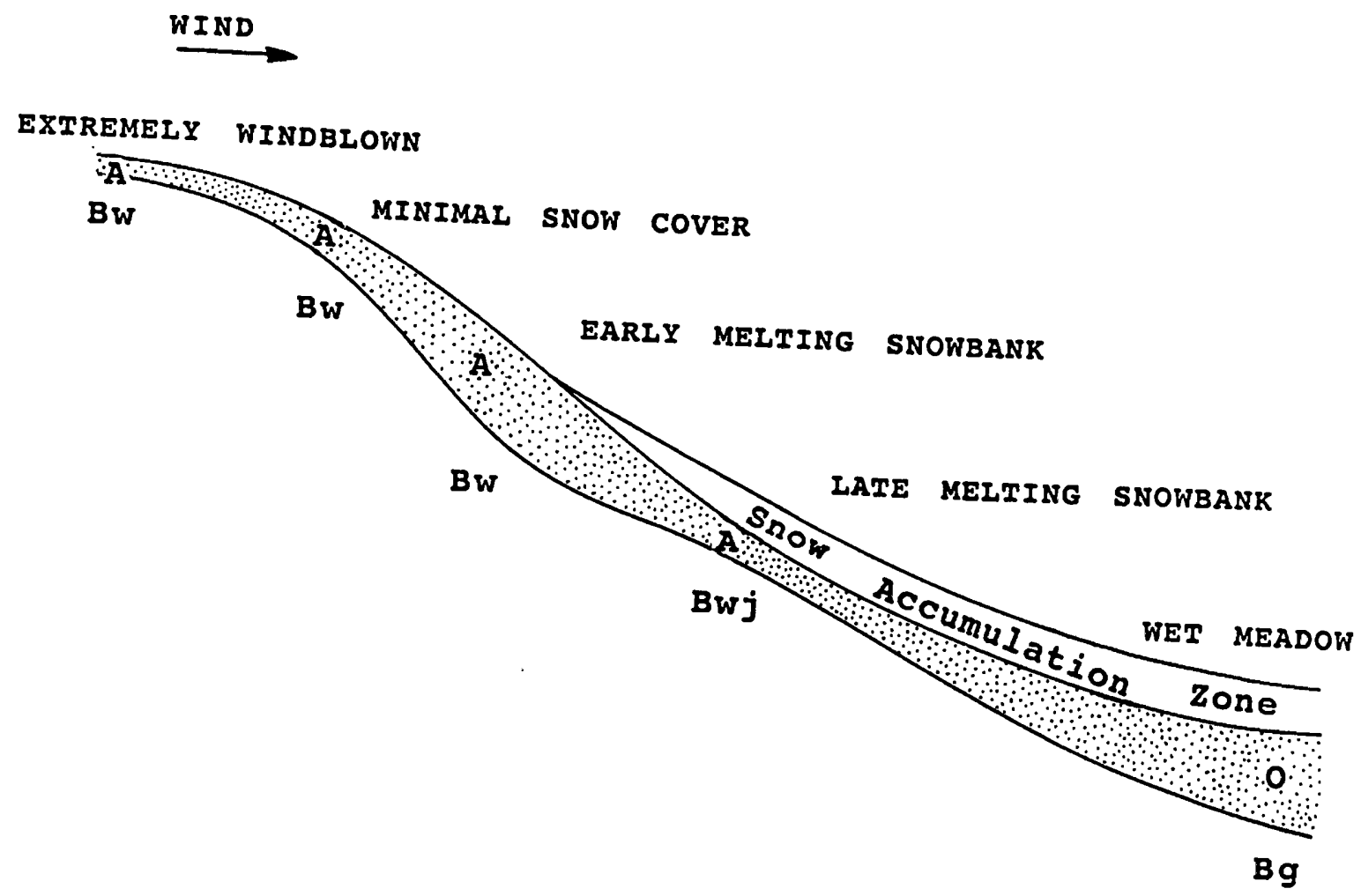

Figure 9. Schematic Alpine Soil Catena. (Adapted from Burns and Tonkin 1982 and Birkeland et al. 1991) Based on Synthetic Alpine Slope model (Figure 8) showing expected soil horizons. Where: $\mathrm{A}=\mathrm{A}$ horizon; $\mathrm{BW}=$ weak $\mathrm{B}$ horizon; $0=0$ horizon; and $\mathrm{Bg}=$ gleyed $\mathrm{B}$ horizon. 
Institute of Arctic and Alpine Research (INSTAAR) in Boulder, Colorado and the United States Forest Service (USFS) Mountain Forest and Range Stations.

One of the earliest studies of alpine soils was by John Retzer (1950). His doctoral dissertation, Genesis and Morphology of Soils of Alpine Areas of the Rocky Mountains, examined the soils from a descriptive standpoint, focusing on individual soil properties. He became the foremost authority on alpine soils, with further work in the Rocky Mountains, culminating in the publication of a summary paper on alpine soils (Retzer 1974).

Alpine soil studies have since been conducted in the Cascades (Douglas and Bliss 1977; Bockheim 1978; Parsons 1978; Dahlgren and Marrett 1991), the Rocky Mountains (Mahaney 1974; Howell and Harris 1978; Burns 1980, 1985; Dixon 1986; Birkeland et al. 1987), the Sierra Nevada (Birkeland and Janda 1971; Birkeland and Burke 1988; Berry 1994), and mountainous areas of Montana, Idaho, Wyoming and Alaska (Bamberg and Major 1968; Ugolini et al. 1981; Mahaney and Spence 1984; Berry 1987; Hall and Shroba 1993; Dahms 1994; USDAFS 1994; Hall and Shroba 1995). Alpine soil studies abroad include the Himalayas (Troll 1972; Righi and Lorphelin 1986), the Alps of Europe (Gensac 1990; Legros 1992) and New Zealand (Archer and Cutler 1983; O'Connor 1984; Tonkin and Basher 1990; Birkeland, 1994). 
Since Retzer's work, alpine soil studies have moved from the earlier descriptive approach to a more process-oriented approach. However, description of the profile is still an important part of understanding soil characteristics. A recent synthesis of previous work adopted a similar descriptive approach and examined a number of mountain areas to correlate different alpine spodosol soils and their related climatic controls (Burns 1990).

Good summaries of the earlier alpine soil studies can be found in Price (1981), who reviewed the recent publications in his book, Mountains and Man: A study of Process and Environment, and Burns (1980) in his dissertation entitled Alpine Soil Distribution and Development, Indian Peaks, Colorado Front Range. Legros (1992) provides the most recent synthesis of alpine soil studies. However, it is heavily skewed toward the European Alps and unfortunately neglects many sources.

In 1982, Burns and Tonkin published what was to be one of the most influential studies in alpine soil geomorphology, using soil-geomorphic models to map and understand alpine soil distribution and development. They commented on the intriguing nature of soil development in the alpine environment, mentioning the interaction of the soil-forming factors in such extreme conditions and how there is often no single overriding influential factor. They also mentioned the relation of the time factor, as alpine soils are relatively 
young, and they take a long time to develop. This means that other factors such as slope angle, slope orientation, rock type, glacial history and climate change, as well as marginal factors such as loess input or size of the mountain mass, are influential in explaining the soil profile (Burns and Tonkin 1982).

\section{SOIL FORMING FACTORS}

\section{Lithologic}

The importance of parent material (lithology) to soil development was established in the studies of Dokuchayev in Russia and Hilgard (1911) in United States. However, the importance of the parent material, and its influence on soil development has since been disputed (Chesworth 1973), arguing that providing there is enough time, the mineralogical composition and chemical effect of the parent material would have little effect on the soil profile. However, Chesworth (1973) focused on older low elevational landscapes, untouched by glaciation, which makes his study less of a factor for alpine areas. The importance of chemical weathering might also be disputed, as in mountain regions it is presumed to be not as important. Therefore, parent material has a larger role in development of young soils, which are more common in alpine areas.

A study by Hall and Shroba (1993) emphasizes the notion of parent material influence, in an area where glacial 
deposits determine the nature of the parent material, as well as the age of the deposits. While providing a correlation of glacial events through studying the deposits and the soils, they found that better soil development signifies greater age, other factors being equal.

Glacial cirque deposits, such as moraines, are useful because they give an age relationship. Radiocarbon dating is often used to correlate different deposits as well as different slope locations to provide a sequence of soil development in time and space. A study in the Colorado Front Range (Birkeland et al. 1987) examined glacial deposits and concluded that the soil had formed fairly quickly. Despite the predominance of coarse sandy materials derived from the gneiss bedrock, the influx of eolian fines was also observed. Mahaney (1974) also noted a presence of eolian sediments in the same area on predominantly granitic-gneissic geology, which raises some questions as to whether windblown sediments accumulate more on coarser parent material. The influence of finer materials is also visible in Litaor's work in the Front Range, where the presence of finer silty material was the most important factor affecting soil development (Litaor 1987). Transported material plays an important part in this thesis in determining whether the alpine soils in the Wallowas are primarily residual soils (composed of mostly weathered parent rock) or are significantly affected by the eolian dusts (Price 1985). 
Early research into the effect of parent rock on mountain soils found that rocks such as limestone were more resistant to chemical weathering processes (Bamberg and Major 1968: 136). Frost processes, on the other hand, were deemed more important than parent material in alpine areas, so that weathering and vegetation controlled the local soil development (Bamberg and Major 1968). Legros (1992) found limestone to be more resistant than granite, providing the environment was relatively dry and the soil likely to be thinner on limestone. He suggests that deepening occurs on limestone owing to the accumulation of residue, especially eolian loess (Legros 1992). The apparent influence of eolian materials has already been documented for the Wallowas and is reflected at lower elevations in soil development in the Lakes Basin (MacCormick 1984).

Parent material research establishes the effect weathering has on the final composition of the soil. A young alpine soil should have similar attributes to the parent material, be it transported or residual. In mountain regions the assumption is that physical weathering is the dominant form of weathering. Chemical weathering is considered to be less important, although it does play a minor part in alpine processes (Gerrard 1990). Too often chemical weathering has been disregarded as a factor, due to the notion that the environment is too extreme. However, this has begun to be disputed recently and chemical weathering studies have 
increased (Caine 1979; Barsch and Caine 1984; Dixon 1986; Pope et al. 1995)

Barsch and Caine (1984) comment that solute transport is just as important as residual breakdown. Pope et al (1995) propose a more localized micro-effect that establishes whether chemical weathering is a factor or not. Their study examines the soils at the microscopic level. They devised a "boundary layer" model to observe the layer where weathering actually occurs and suggest further studies investigate this idea. When chemical weathering occurs, it is mainly due to the presence of snow and glacial meltwater as discussed by Dixon et al. (1984) in studying a periglacial nunatak in Alaska. Chemical processes work as free water aggressively modifies the granodiorite-migmatite nunatak. The relevance of this study relates to the Wallowas, since Eagle cap is granodiorite and believed to be a nunatak. The environment in Alaska is much more extreme than in oregon, but perhaps corresponds to the Wallowas during the Quaternary. Alpine soil development would have continued above 2,893 meters where there were nunataks (Carson et al. 1995).

\section{Climatic}

According to Shroba and Birkeland (1983), in any alpine system the climate will be highly influential, but like parent material influence, it will largely be as a factor of time (climate change). Although the climate affects the location of treeline and therefore soil distribution, the 
interrelationship with topography is also visible in the distribution of alpine soils. This is especially evident when examining glacial or periglacial features in mountain areas, which are related to both the climate and topography. Climate change and micro-climate are major factors affecting alpine soil development and distribution.

It is difficult to examine how climate change has affected alpine soil development and distribution. Some studies have proposed fluctuations in treeline related to climate (Ugolini et al. 1981) as well as soil development above the level of the ice (Dixon et al. 1984; Price 1994). Although this has provided an estimate of the extent of climatic change since the last major glacial period, microclimate seems to have much more of a bearing on this particular study.

Micro-climate affects soil distribution mainly through its interrelationships with the topography. The winds are strong in an alpine environment. Microtopographic changes create many windward and leeward sites with their own microclimates. Soil is able to develop depending on the extent of vegetation as well as snow cover. Similarly, good soil development is unlikely on windy ridges.

While the effects of climate on alpine soil are numerous (Birkeland and Janda 1971; Barry 1973; Tardy et al. 1973; ollier 1976; Caine 1979; Bockheim 1980; Harden and Taylor 1984; Reheis 1990; Birkeland 1994) a theme that runs 
throughout alpine soil studies is the interrelationship of climate with the topography that creates a micro-climate and in turn affects the soil.

\section{Biologic}

Vegetation distribution is controlled primarily by topography and microclimate, so it is difficult to account for the direct effects of vegetation on soil development (Birkeland 1984). One effect is evident as treeline varies according to the slope aspect (Billings and Mooney 1968); for example, in the Wallowas the treeline extends further up the south-facing slopes, where it is warmer.

Earlier alpine soil studies that deal with the effects of vegetation on soil, range from minimal use (Howell and Harris 1978), to extensive use (Burns 1980) where vegetation maps were used to interpret soil variations. This is especially possible in alpine soils, being as a definition of alpine areas has become synonymous with the area beyond treeline, or tundra. Thorn (1988: 85) argues that the use of vegetation variation types on the alpine tundra is merely a substitute for the seasonal distribution of snowpack. This certainly holds true for the high-alpine zone, but in cases where the area is marginally beyond treeline, such as the Wallowas, and there are instances of localized variations in climate, vegetation should not be disregarded. Price (1994) argues the importance of vegetation, noting that an ecological inversion occurs on Eagle Cap, where earlier snow 
melt on the higher ridges creates an earlier spring bloom than in the Lake Basin below. This still depends on snowfall and accumulation and suggests a correlation between these factors and the apparent increased soil development on Eagle Cap.

Further studies on the effects of treeline at the boreal forest-tundra transition in Alaska (Ugolini et al. 1981) reject the influence of tree cover on soil development. Instead, attempts are made to explain the uniform soil appearance by suggesting a fluctuating treeline caused by climate change or recent tree invasion. However, a recent study by Burns (1990) used the biologic factor. He stresses how vegetation strongly determines soil distribution and is especially useful in determining alpine spodosols. For this reason vegetation has an important use in demarcating the forest-tundra ecotone and in some cases a paleotreeline.

Birkeland (1984: 260) stressed the importance of the microclimate effect. The former vegetation and forestgrassland boundary were the most important elements. Soil changes are subtle (Birkeland 1984: 262), and soil chemistry analysis is a necessity when examining the change, mainly in organic matter, such as carbon, nitrogen and so forth.

The influence of vegetation in alpine soil development and distribution clearly relates to climatic control, such as treeline extent (Barry 1973; Troll 1973; Wardle 1974). For many alpine soils studies though, time and geology are 
seemingly more important than vegetation (Shroba and Birkeland 1983).

Previous vegetation-related soil studies in the Wallowas have dealt mainly with lower elevations (Strickler 1961; Geist and Strickler 1970). The soils have largely been affected by grazing and recreation. However, whereas grazing has ceased, recreation has not, and people can create serious soil degradation. There have been fewer soil studies at higher elevations (Cole 1982; MacCormick 1984; Price 1994). In many cases, the soils are simply weathered parent material, although a study by Price (1994) noted the extent of soil development at higher elevations in the Wallowas. He suggested that soil development might be related to the ecological inversion, as well as the nunatak-refugia notion suggested by Ives (1966). This maintains that during the Pleistocene, alpine vegetation survived as island communities above the ice. Soils were able to continue to develop, and therefore are often deeper. The question remains whether the eolian input is more important than the residual breakdown, a notion supported by the vegetation entrapment of wind-blown sediments.

\section{Topographic}

The assumption that spatial phenomena are highly visible in the alpine setting was first acknowledged by Burns and Tonkin (1982). They observed that topography, especially micro-topography, when combined with wind controlled snow 
cover, which in turn dictated the vegetation type and distribution and loess entrapment. Topography is of vital importance to the appearance of a soil, as it affects soil moisture. Topography also relates to snow or loess accumulation, which generally falls on the leeside and is entrapped. Burns and Tonkin (1982) also suggested that on a soil catena in alpine areas, lower pH's occur downslope, and there is more organic carbon upslope, which relates to vegetation and eolian loess infiltration rates.

The usefulness of topography in understanding alpine soils is visible in the frequently used concepts of catenas and chronosequences which provide a sequence of soil change in time, as well as in space. It is this tool that is probably most valid for soil geographers, shown in studies by Burns (1985), and Birkeland, Machette, and Haller (1991).

Especially important to topographic areas is aspect, slope and elevation, as it affects vegetation, climate, and rates of weathering. The Howell and Harris study (1978), mentioned how topography controlled soil moisture. A similar study was conducted in the Wind River Mountains of Wyoming (Mahaney and Sanmugadas 1983) showing changes in soil morphology mid-slope due to poorer drainage. Dixon (1986), on the other hand, observed vertical and lateral movement of water and cations which affected the soil appearance more than the changing topography. 


\section{CHAPTER IV}

\section{THEORETICAI CONCEPTS}

\section{INTRODUCTION}

Theory in soil geomorphology deals with the notion that soil development may be used to understand the landscape and explain the surficial processes that occur. A soil that has taken a certain time to develop, provides a history of that particular landscape. Models have been proposed to enable a greater understanding and possible prediction of soil development within the landscape. The most popular theories state that soil differs primarily according to factors in space and time (Burns and Tonkin 1982). In most cases the results are not actually visible but are inferred.

In any soil system the soil forming factors vary in time and space. In an area along a slope, a soil might vary in age, or composition. To enable a thorough understanding of the interrelationships between the soil and its environment, two major divisions can be made. Variation in space is explained by recognizing the variation across the landscape, whilst accepting that any changes in soil are not related to the age of the process. The changes might include different vegetation types, rock types and so forth. These models are known as spatial models. 
A second theory is that of the state of time. This occurs where similarities are visible in the environment, but dating shows the soils to be of different ages. This might explain either the time it took the soil to form, or when the soil formed. The idea of temporal variation in soil morphology favors the geologist. The most accepted model is that of the chronosequence, that helps determine age of deposits and can be related back to certain events such as interglacial periods.

\section{SPATIAL CONSTRUCTS}

Spatial studies in soil geomorphology are concerned with a landscape that is of a similar age, but differs in the way the variables of climate, parent material, topography, and vegetation interact. Such studies require a model to allow for simple examination of these phenomena. Catenas provide a model of soil distribution on a slope (Milne 1935), but on the alpine tundra, it is rare to find one slope that has all the possible slope positions of the area. Therefore the aforementioned Synthetic Alpine Slope (SAS), based on Butler's (1959) K-cycle and Caine's (1979) geomorphic subdivisions was devised (Figure 8). The Synthetic Alpine slope model is used for the ridge top tundra geomorphic province and uses topography, wind and snow to determine their variable effects on soil distribution (Burns and Tonkin 1982). The model is based on the spatial relationships 
between aspect, topography, seasonal snow accumulation, and distribution of plant communities, alpine loess and snow.

\section{Soil Catenas}

The soil catena is probably the most widely used model in all of soil geomorphology. The catena was first fully utilized by Milne (1935). It was originally defined as a convenient system for modeling soil changes along a slope that decreased, or increased, in elevation (topographical change). This topographical relationship was taken to mean that a soil varies in depth and development related to the changing slope. However, the catena is now used to describe any differences that occur along a particular slope. This makes it especially useful in examining the effects of timberline (vegetation change) and geology on the landscape. Therefore, catenas provide an attempt to explain both spatial and temporal problems.

Difficulties that may arise in alpine soil studies have meant that the use of alpine soil catenas require their own particular theory. Alpine catenas are especially useful for this type of study, for they should show differentiation in their profiles along a particular slope (Birkeland et al. 1991). In the Wallowas not only does the topography change, but also other variables across the slope, such as parent material and vegetation. 
TEMPORAL CONSTRUCTS

Time has long been recognized as a cyclical element in any geomorphic study. This is commonly expressed in the notion that a surface continually erodes and reshapes the landscape. This idea was first explained in the late 19th century in the Geographical Cvcle by William Morris Davis (1899). A contrary notion is that at no time does a landscape change. Instead, with deposition comes erosion to maintain a steady state of equilibrium. Both of these ideas are accepted partially, and both affect the understanding of the environment in which soil develops.

These ideas were well expressed in geomorphic studies by Butler (1959). His idea of the K-cycle deals with the redistribution of sediment in a continual erosion-deposition cycle. This means that at times when nothing appears to be happening (lack of dynamism or stability), a soil is able to develop. The evidence for this is provided by the visible development of soils during interglacial stages in the Pleistocene. Butler's model (1959) has been expanded into a framework for investigating the phenomena of time in soil development. This led to the development of the soil chronosequence. However, despite the usefulness of this, the spatial factors can never be ignored, and vice versa. 
The Soil Chronosequence

A soil chronosequence is the "...sequential variation in soils of particular soil properties on landforms and deposits of different age" (Birkeland et al. 1991: 20). Essentially, soils on a slope of similar qualities, be they lithology or vegetation, are different ages.

Soil chronosequences examine the importance of the temporal variable in soil formation. In chronosequence studies, the factors influencing soil formation do not vary across any given surface. For example, rock types may be similar, and yet the ages of the soils differ. This would indicate that the soil of a certain site is either younger or older than the one at another site. In other words, all factors are equal except time. This makes it popular for geologic soil studies.

Similarly, when attempting to date events in a particular landscape, soil chronosequence studies are especially useful. They have been used effectively in numerous studies, exemplified by Bockheim (1980) where he attempts to construct a chronofunction, or a correlation of soils from different areas. The similar variables were climate and parent material. This allows for considerable similarity in age, or time taken for soil formation. Chronofunctions as discussed by Bockheim are basically chronosequences that are similar in composition though not locality (Bockheim 1980). 
CHAPTER $\dot{V}$

\section{METHODOLOGY}

\section{SELECTION OF STUDY SITES}

Alpine soils in the Wallowa Mountains occur in the higher elevations of the Eagle Cap Wilderness area (Figure 10). In order to provide an understanding of the alpine pedogenic process, sites were selected primarily above 2,700 meters, the lowest extent of alpine timberline (Mason 1975; Price 1978). Owing to the narrow alpine zone, there were few soils available for study. Those sites selected were where a change in soil-forming factors, such as lithology, vegetation, and topography occurred. In order to select sites effectively, while descending along the hiking trail, path cut-banks were closely examined and soil samples collected from sites that were deemed representative of the immediate area. The sample sites along the catena maintained a northnorthwest aspect on Eagle Cap and a north aspect between Matterhorn and Sacajawea. The Matterhorn is particularly interesting due to its geologic composition. The "marble mountain" was chosen to provide answers related to the importance of geologic factors, especially the influence of eolian sediments. 


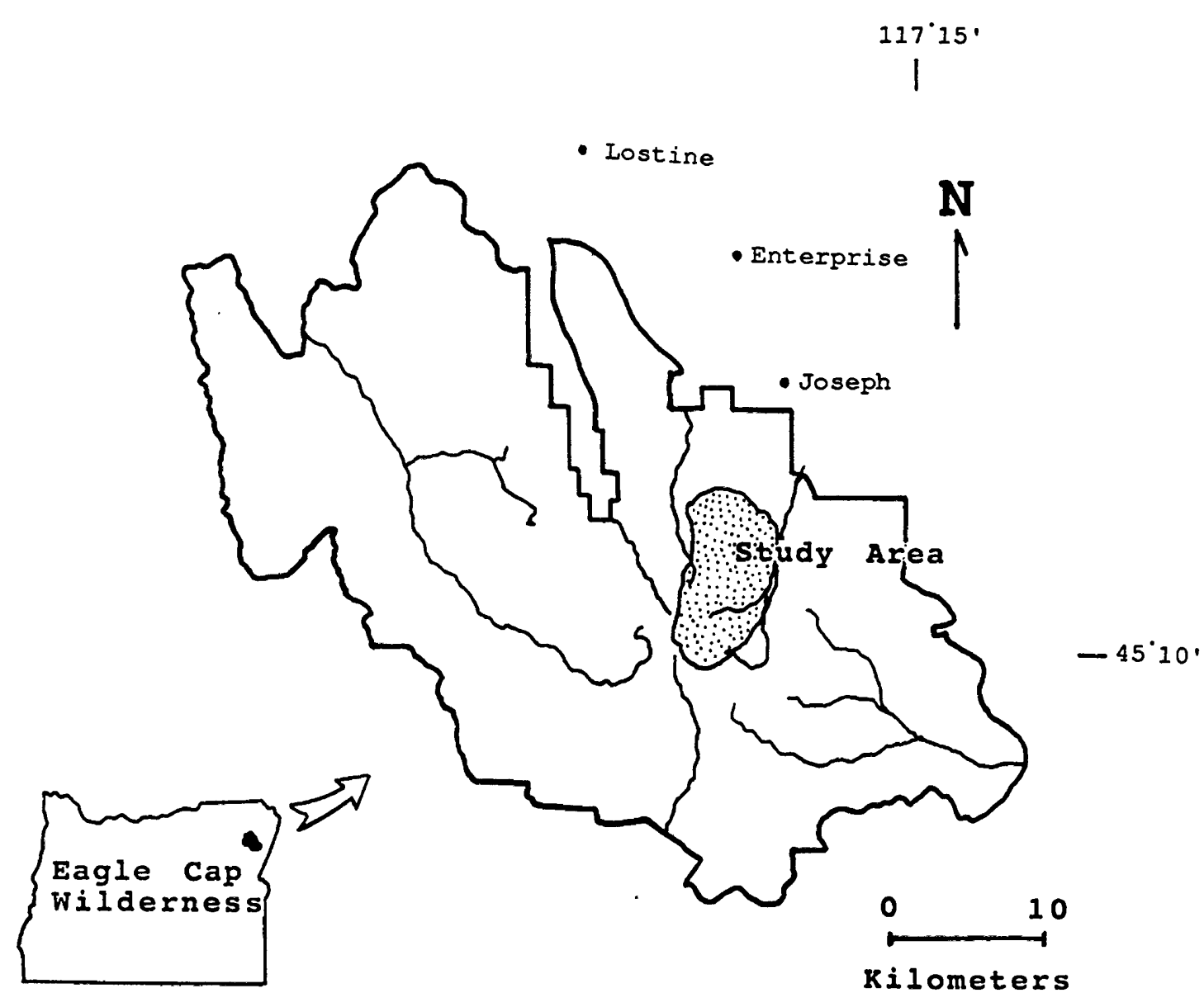

Figure 10. Eagle Cap Wilderness. Shading shows the location of the study area. The towns are provided for geographic reference. (Adapted from Cole 1982) 
Slope gradient for the catenas was calculated to determine the influence changing topography had on soil development. While there was no presumed climate or time difference, local factors were expected to be influential, primarily ash content, microclimate (snowcover and wind), eolian influx, size of mountain mass, and disturbance. Finally, study sites were required to be above the desired elevation, 2,700 meters (Figure 11).

An additional constraint that always affects alpine environments is the weather. This meant that field work was conducted during the latter part of the summer, 1994. The laboratory analysis did not require as much planning and travel, and the bulk of this was carried-out throughout the winter, 1994-95.

\section{FIELD METHODS}

Catenas were devised to assess the nature and characteristics of alpine soils in the Wallowa Mountains (Figures 12 and 13). Advance preparation was required to determine the extent of the catenas, mainly due to the particular terrain and the nature of the mountain climate. The Portland State Mountain Geography field camp in summer 1993 provided five days in the Lakes Basin for reconnaissance. This was followed up with cartographic planning and eventually two field trips in August and 


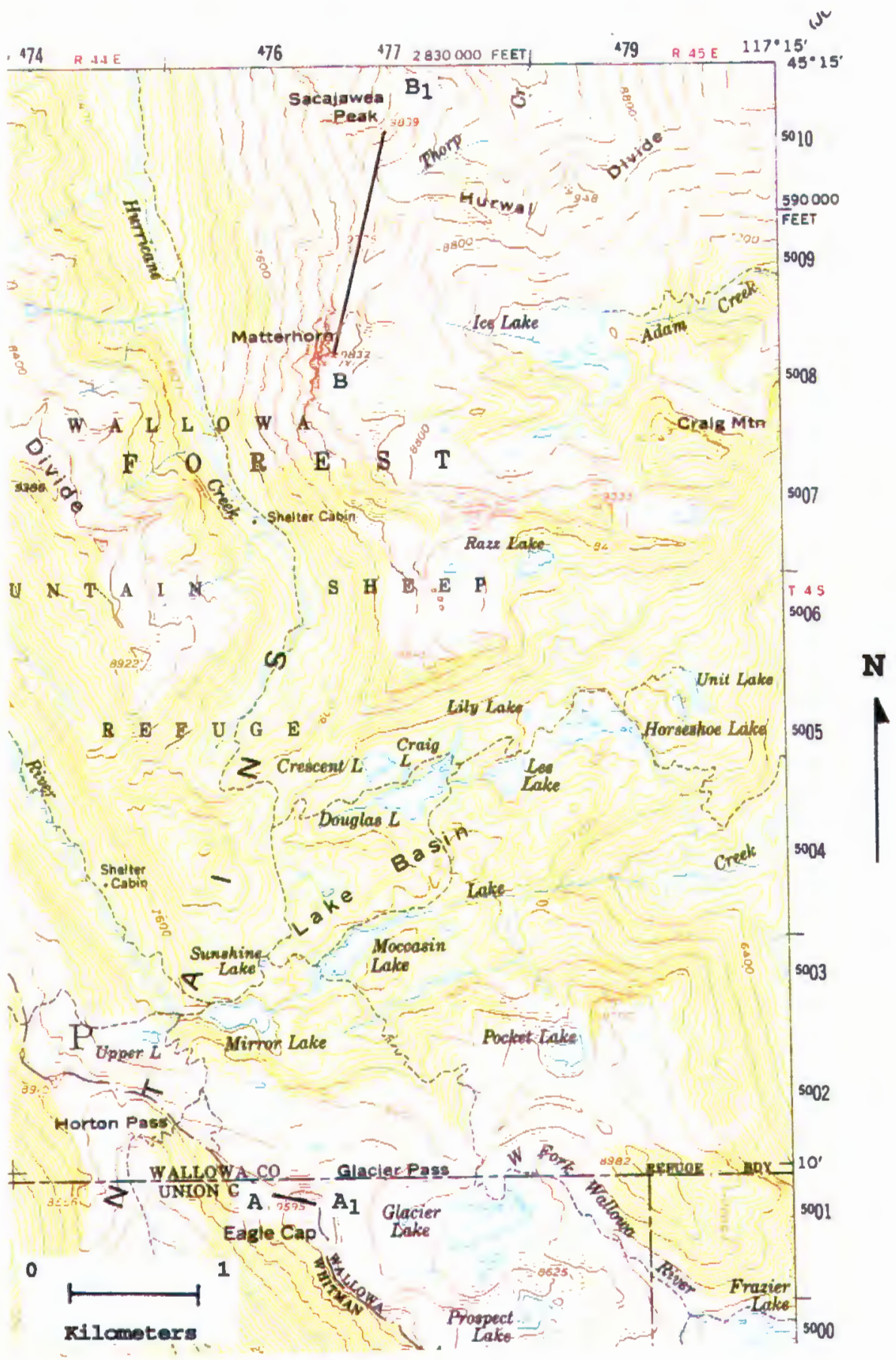

Eigure 11. Lake Basin Study Area. The extent of the catena transect from Eagle $C a p$ is listed as $A$ to $A_{1}$, while the transect between Matterhorn and Sacajawea is $B$ to $B_{1}$. (USGS Eagle Cap, Oregon Quadrangle 1.954, scale $=1: 62,500$ ) 


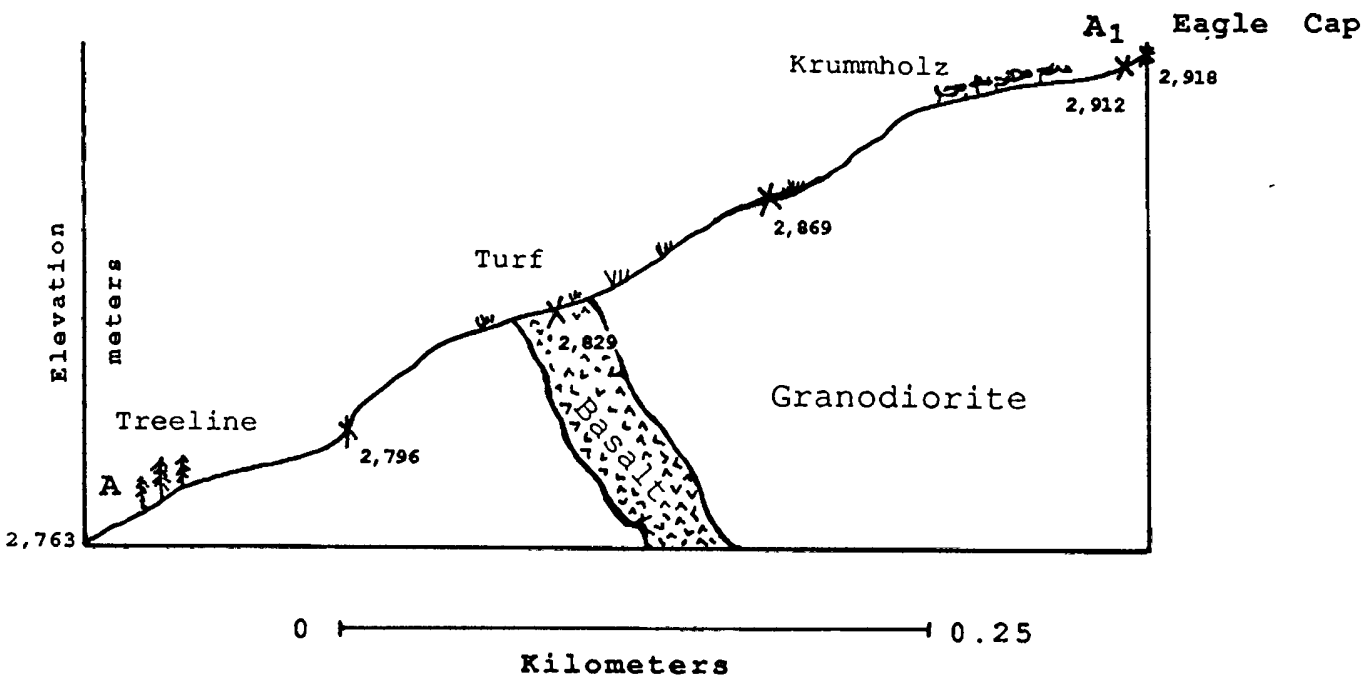

Figure 12. Eagle Cap Catena Cross-Section. A to $A_{1}$ is the extent of the catena, with $X$ 's showing sample sites and corresponding elevation. Changes in parent material and vegetation are shown on the diagram.

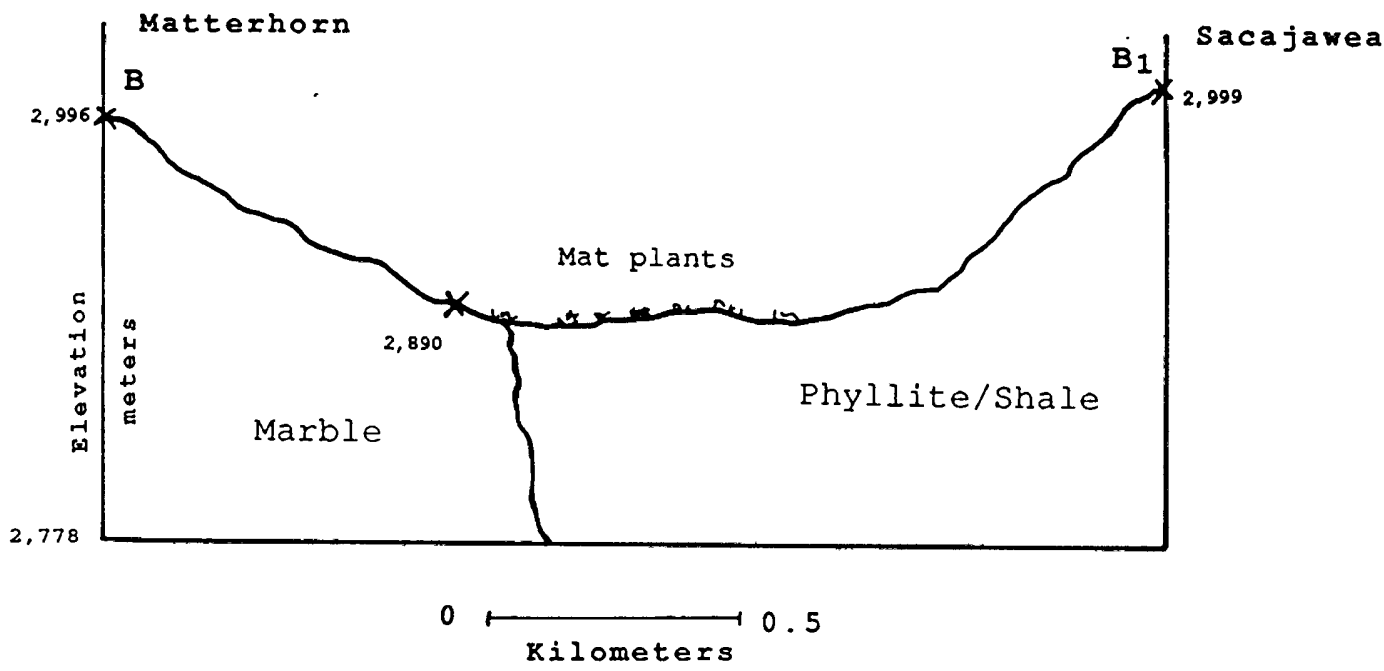

Figure 13. Matterhorn-Sacajawea Cross-section. B to $B_{1}$ is the extent of the catena, with $X$ 's showing sample sites and corresponding elevation. Changes in parent material and vegetation are shown on the diagram. 
October, 1994. The primary collection of soil samples for laboratory analysis was carried out on the 1994 expeditions.

The first site, Eagle Cap, offered the best chance to examine the soils in a catena-like sequence, because it provided a changing slope that included differing lithology and vegetation (Figure 12). The method used at all sites was to first examine the area and then choose a suitable location, by examining trailside cut-banks to determine the uniformity of the soil. Then a soil pit was excavated. Once the pit was dug, the soils underwent preliminary analysis. This involved the visual examination of the profile, checking for horizonation, and depth of development. A description was made following standard procedure, noting soil color, structure, and texture (Soil Survey Staff 1992), and photographs taken. The horizons were named and the depth of soil was measured. The next step was to physically analyze each of the soil horizons, followed by field textural analysis using fingers to see how developed the soil was (Birkeland 1984). Next, the moist soil color was checked using the Munsell color charts (Munsell Color Company Inc 1954), and the results noted. Then the profile was examined for any evidence of structure (Soil Survey staff 1975). The final step in the procedure was to collect samples from the different soil horizons. Typically, one 1.89 liter bag was sampled from each horizon for laboratory analysis. 


\section{LABORATORY ANALYSIS}

Laboratory analysis of the soil samples involved several tests. The primary aim was to understand soil properties and determine the primary component in soil formation. The first procedure was simply to analyze under natural sunlight the wet and dry soil colors for each sample (Munsell Color Company Inc 1954). The results were recorded for each horizon.

The soil samples were separated by particle size analysis using a modified Bouyoucos method (1936). The following boundaries for particle size were used:

$$
\begin{aligned}
& \text { Sand }=2 \mathrm{~mm} \text { to } .063 \mathrm{~mm} \\
& \text { Silt }=.063 \mathrm{~mm} \text { to } .002 \mathrm{~mm} \\
& \text { Clay }=<.002 \mathrm{~mm}
\end{aligned}
$$

Separation involved taking a 100 gram sample and removing through sieving, the particles larger than sand. Organics were removed from the A horizon samples using the $\mathrm{H}_{2} \mathrm{O}_{2}$ method. The sand, silt, clay particles were disaggregated by sodium hexametaphosphate (deflocculant) and wet-sieved. The remaining sand fraction was dried and sieved into increments, based on phi sizes. To measure the finer materials, a process involving and hydrometer testing in a $1,000 \mathrm{ml}$ cylinder was conducted. After the hydrometer testing silt samples were collected for later mineralogical testing. The results were plotted on Cumulative Frequency Curves (Appendix B), particle size statistics developed using Lewis' 
(1984) method, and the resulting textures (Soil Survey Staff 1975) were noted (Appendix A) .

Soil pH was sampled in three ways using a Chemtrix 41100 $\mathrm{pH}$ meter with a whatman $\mathrm{Ag} / \mathrm{AgCl}$ electrode (Procedure 8Cla, USDA 1972). The first $\mathrm{pH}$ test was a standard USDA 1:1 water (ten grams of distilled water to ten grams of dried soil) test to provide an acidity reading for the soil (Procedure 8C1a, USDA 1972). The second test was to check any biological/plant influence, using a $2: 1$ test for organic content (Soil Survey Staff 1975: 388). A solution of soil and water was combined with .02M of calcium chloride $\left(\mathrm{CaCl}_{2}\right)$ (Procedure 8Cle, USDA 1972). The expected results were pH readings that were lower than the $1: 1 \mathrm{pH}$ values. The final $\mathrm{pH}$ test was a Sodium Fluoride (NaF) $\mathrm{pH}$ test (Appendix C) which tests for carbonates, gibbsite and amorphous aluminum in soils (Fieldes and Perrott 1966). This was used to determine whether there was a high aluminum content, typical of soil influenced by volcanic ash. This provided the results to conclude whether the Mazama ash had any bearing on the development of the soil. It was expected that the $\mathrm{pH}$ levels would reflect the extensive covering of Mazama ash throughout Oregon, and therefore be above ten. The high $\mathrm{pH}$ readings relate to the immobility of aluminum in the soil, therefore making aluminum readings remain unchanged. However, possible side-effects may be incurred such as the raising of the aluminum level due to increased precipitation, although this 
depends on suitability of the original ash composition (Bockheim et al. 1969: 172).

The key laboratory test was the determination of organic matter using the Walkley-Black method (Allison 1965). This establishes the quantity of organic carbon in the soil, using potassium dichromate $\left(\mathrm{K}_{2} \mathrm{Cr}_{2} \mathrm{O}_{7}\right)$, as the dichromate ion in acid solution strongly oxidizes any carbon that is present. The Walkley-Black test is used because soil organic matter contains approximately 58\% carbon, so the titration results can be multiplied by 1.724 (the approximate empirically derived relationship between organic matter and organic carbon) to give an organic matter content. The results were recorded when the color of the titration solution changed from green to blue and finally red.

Silt mineralogy, the final test, is an important part of weathering studies, especially when there is possible eolian input. Silt mineralogy tests (Appendix D) were used to establish the mineral component of the silt-size particles, while providing evidence as to where the silt was derived from. This would prove to be especially beneficial in the areas of limestone, where soil development was solely due to allochtonous (eolian material) influence. 


\title{
CHAPTER VI
}

\author{
RESULTS \\ FIELD SOIL PROPERTIES
}

\section{Eagle Cap Catena}

The Eagle Cap catena provides the best alpine catena to study the development and distribution of alpine soil in the Wallowa Mountains, due to the differing pedogenic factors, as required by the methodology, over a fairly short distance.

Eagle Cap (Figure 14), at 2,918 meters, is the central peak in the Wallowas and the primary study site. It is composed of intrusive igneous rocks, primarily cretaceous granodiorite, although there are some mafic dikes that outcrop near the summit (Nolf 1966). The study catena moves downslope from south to north, extending from the peak toward the saddle, at 2,796 meters, just above Horton Pass.

Although four sites were selected, an earlier site had been examined during summer 1993 (Figure 15). This is included in the catena profile, but no lab tests were conducted, and the results were obtained from simple field examination.

The 1993 site was located on a windy ridge just above Horton Pass, at an elevation of 2,796 meters. 


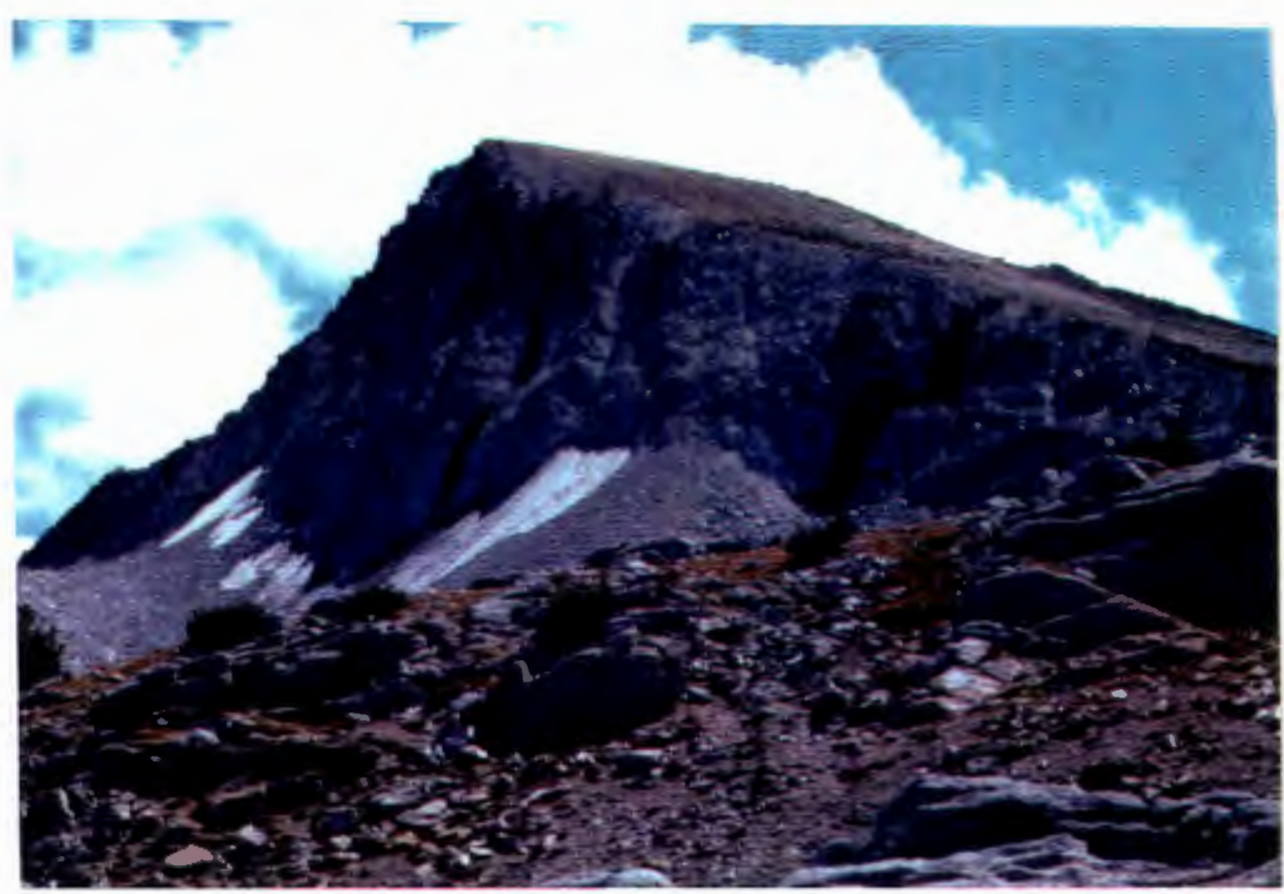

Eigure 14. Eagle Cap. Summit as seen from the north face. Note late-lying snow in cirque and basalt dikes. Photograph taken near Horton Pass.

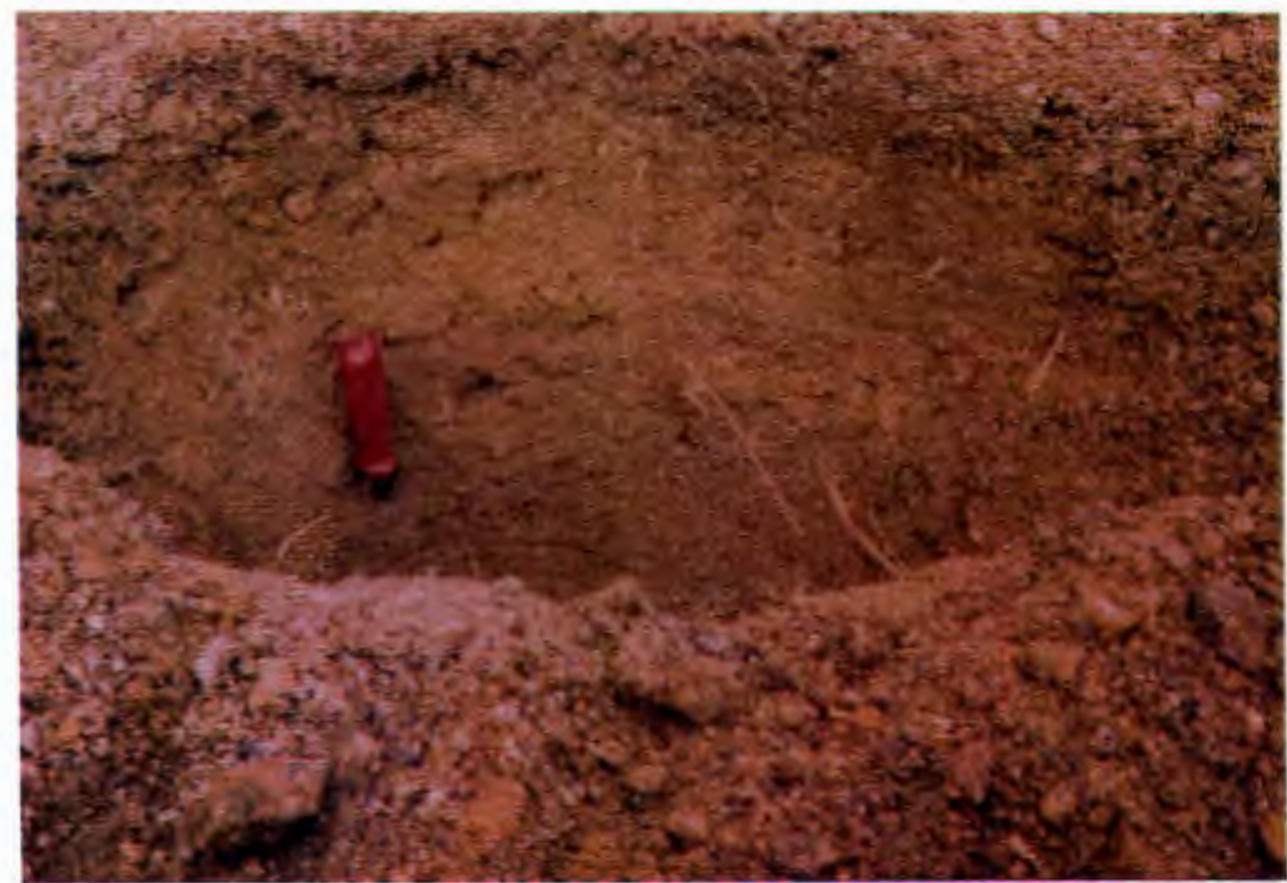

Eigure 15. Soll Profile 5EC. Taken during summer 1993. Screwdriver for scale. A horizon ends just above screwdriver. 
The soil profile was fairly shallow, with a thin A horizon (less than $10 \mathrm{~cm}$ ) overlying a weak $B$ horizon ( $\mathrm{Bw}$ ). The total soil depth was $28 \mathrm{~cm}$ before reaching granodiorite bedrock. The different horizons were determined by an apparent minor color change with depth. The pH also changed, increasing from 7 to 7.2, becoming less acid as the profile deepened, although this was only field tested. The poor soil development, mainly coarse gravel, was due to its location on a fairly narrow, exposed, windy ridge, with little vegetation cover.

Trenches were dug at four major study sites during the summer of 1994. All of these sites occurred at higher elevations than the preliminary location. The sites were examined moving down the catena to observe the effects of the different factors. All except one of the sites were on granodiorite. The topography fluctuated from a gentle slope at the summit, to about a 45 degree slope in places. Vegetation ranged from small clumps of Pinus albicaulis krummholz at the summit, to alpine grasses and herbs along the rest of the slope.

The site chosen for the first soil pit (1EC) was slightly to the south of the Eagle Cap summit (Figure 16) in a place not trampled by climbers and had a depth of $45 \mathrm{~cm}$ (Figure 17). The soil was mostly single grains throughout a structureless profile, with a high percentage (75\%) of coarse particles (greater than two $\mathrm{mm}$ in diameter), as well as some 


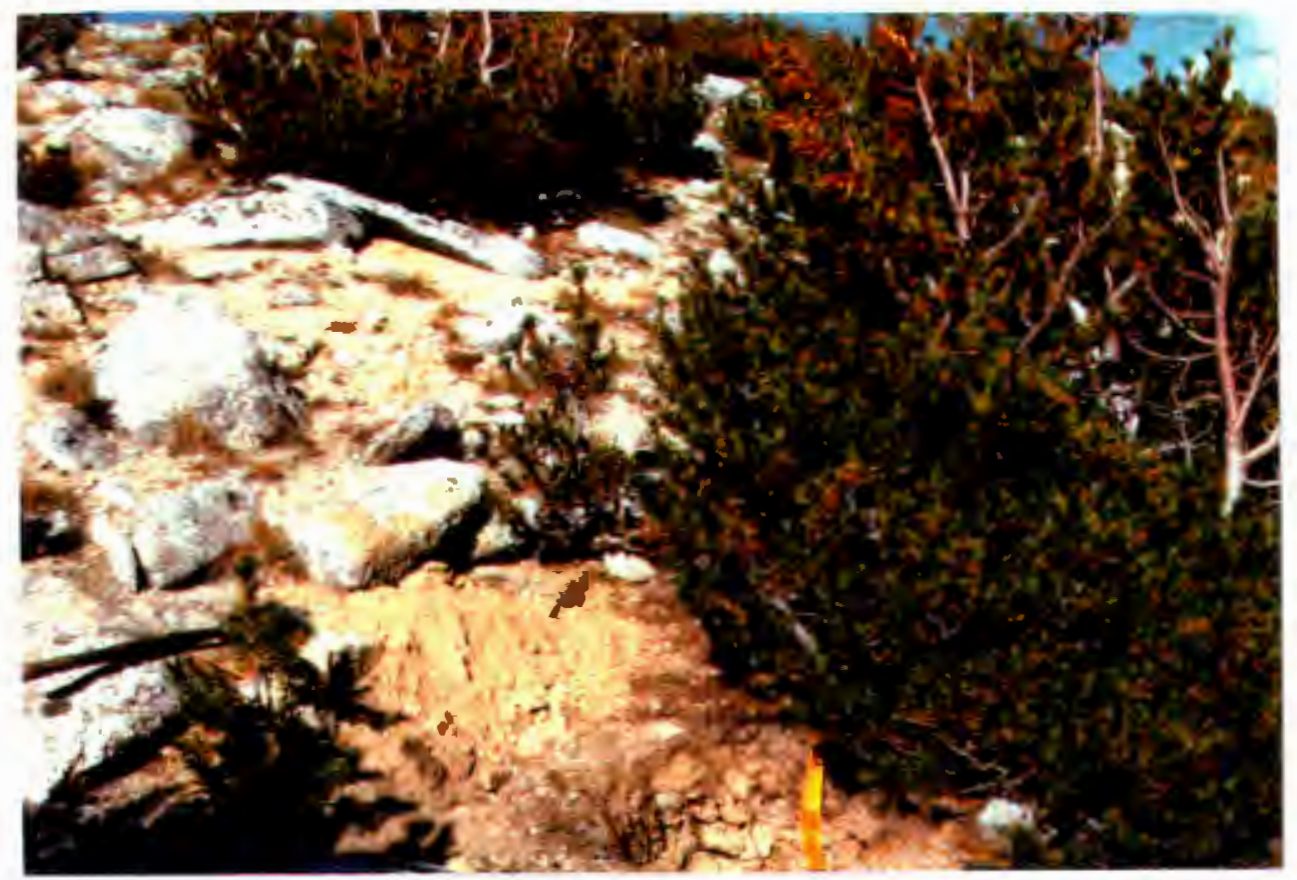

Eigure 16. Eagle Cap Summit Site of Soll Pit 1EC. Situated under krummolz vegetation.

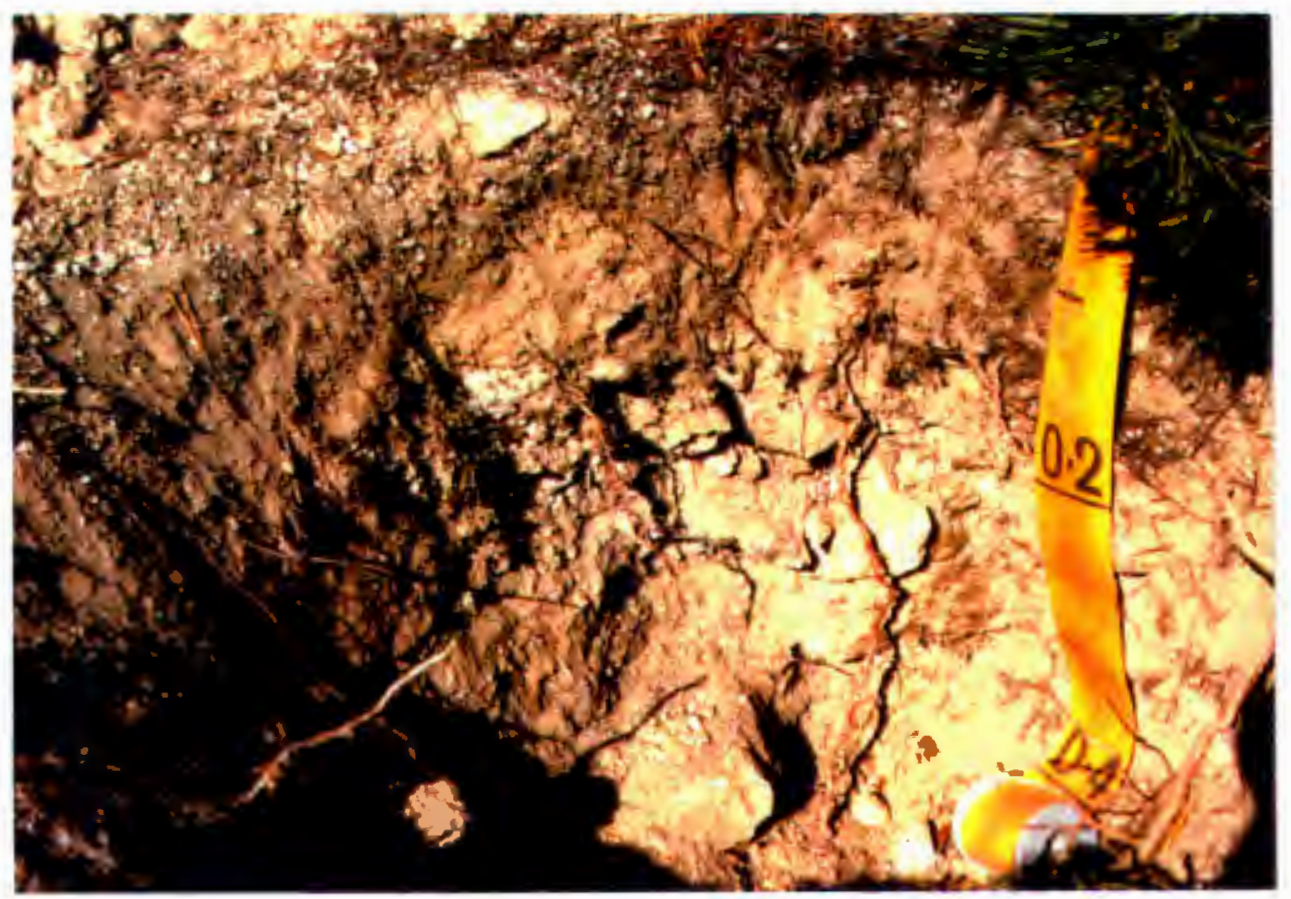

Eigure 17. Soil Profile 1EC. 
larger granodiorite rocks (Appendix A). Soil consistence was loose, non-sticky and non-plastic, and yet there were enough fines present to classify the texture as loamy-sand. There was definite horizonation in the profile, especially visible after wetting the soil.

An A horizon occurred beneath the Pinus albicaulis krummolz and subsequently underlay a thin 0 horizon of organic matter (less than $2 \mathrm{~cm}$ ). The Munsell color (all colors listed were measured when moist) for the A horizon was a very dark grayish brown $(2.5 y 3 / 2)$. There was a clear, wavy boundary separating the A horizon and Bw (weak B horizon) horizon at a depth of $2 \mathrm{~cm}$. The soil texture was dominated by unsorted, coarse, granodiorite particles, which meant the Bw horizon was identified by way of more fines and less organic matter, especially as the Bw horizon was also a very dark grayish brown $(2.5 \mathrm{Y} 3 / 2)$ color. Both the $\mathrm{A}$ and the $\mathrm{BW}$ horizons overlay a Cox (oxidized C) horizon that occurred at a depth of $8 \mathrm{~cm}$, although the boundary was rather gradual and not distinct. The cox horizon was much the same as the overlying soil, but was significantly coarser due to the abundance of weathered bedrock. The horizon color was olive (2.5Y 4/4), and therefore much lighter, which provided the distinction. Bedrock was encountered at a depth of $45 \mathrm{~cm}$.

Although field classification was awkward, the soil was classified tentatively as a Lithic Dystric Cryochrept. It was presumed that the soil had a cryic soil temperature regime, 
bedrock was reached at a depth less than $50 \mathrm{~cm}$, and there was an ochric (thin and weak) epipedon. There were certainly enough finer particles, organic content and color difference to call this a soil, albeit a poorly developed one.

The expected scenario in moving downslope was that the soil profile would deepen. Therefore, a second pit was dug in a more exposed area (WB site, Figure 8), to the northwest of the summit along the saddle, at an elevation of 2,912 meters (Figure 18). However, the soil (2EC) exhibited a profile similar to the summit, and there seemed to be little change in texture or organic content (Figure 19). The vegetation was primarily alpine herbs and grasses set apart from the krummholz vegetation. The Bw horizon appeared slightly thicker $(40 \mathrm{~cm})$, although this may be due to difficulty in establishing the boundary between the $A$ and $B$ horizons. The $A$ horizon was less influenced by vegetation and therefore not as dark. One difference between this site and the summit was that the soil profile was deeper, probably due to increased moisture, and contained fewer rocks. No samples were taken at this site, as it was deemed to be the same classification to the soil profile at the first site.

A sharp increase in soil depth and horizonation, was noted at the third site (3EC, Figure 20), which reached $85 \mathrm{~cm}$ above the underlying granodiorite bedrock (Figure 21). This was also a fairly wind-blown site (MSC site, Figure 8), with a slope angle of 23 degrees and an elevation of 2,869 meters. 


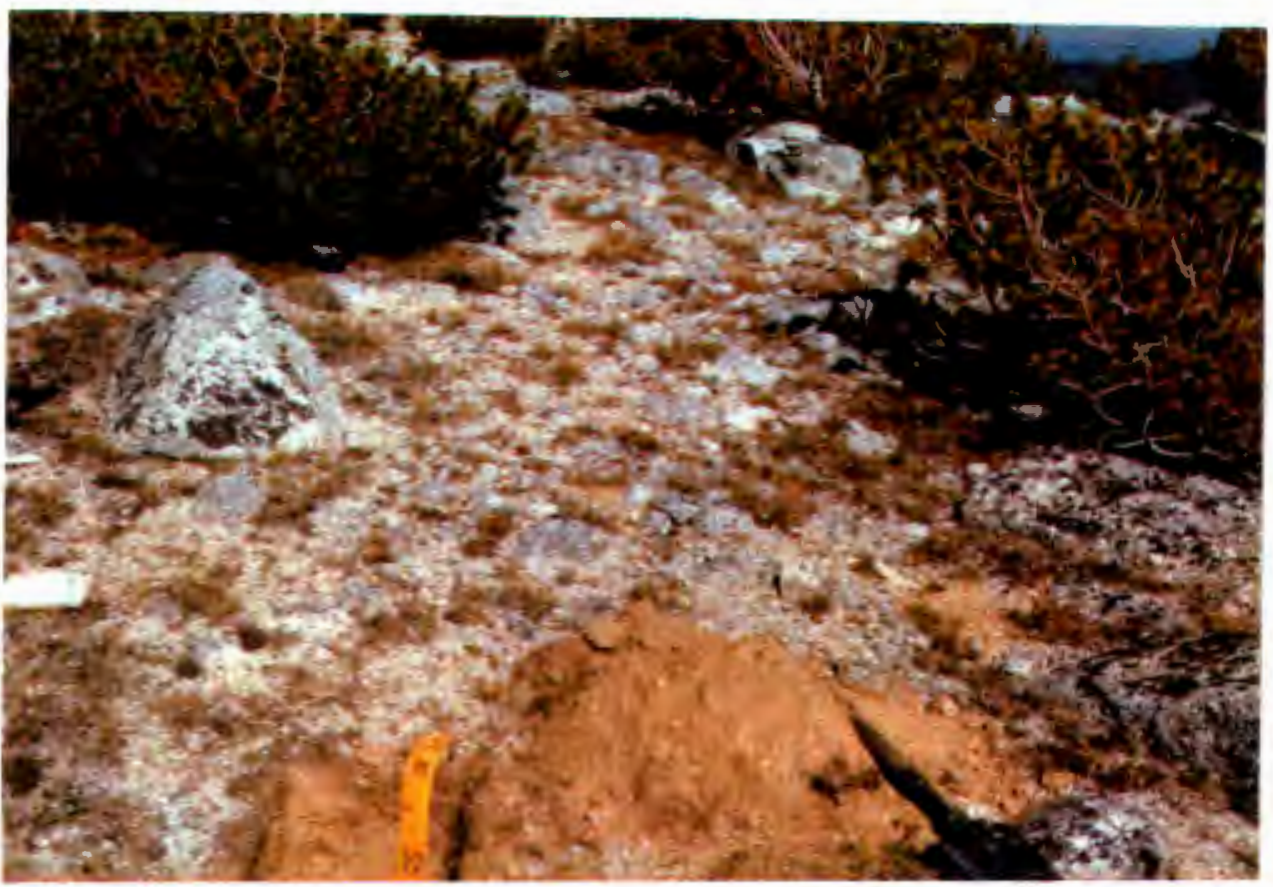

Eiqure 18. Eagle Cap Site of Soil Pit 2EC. Note alpine mat plants.

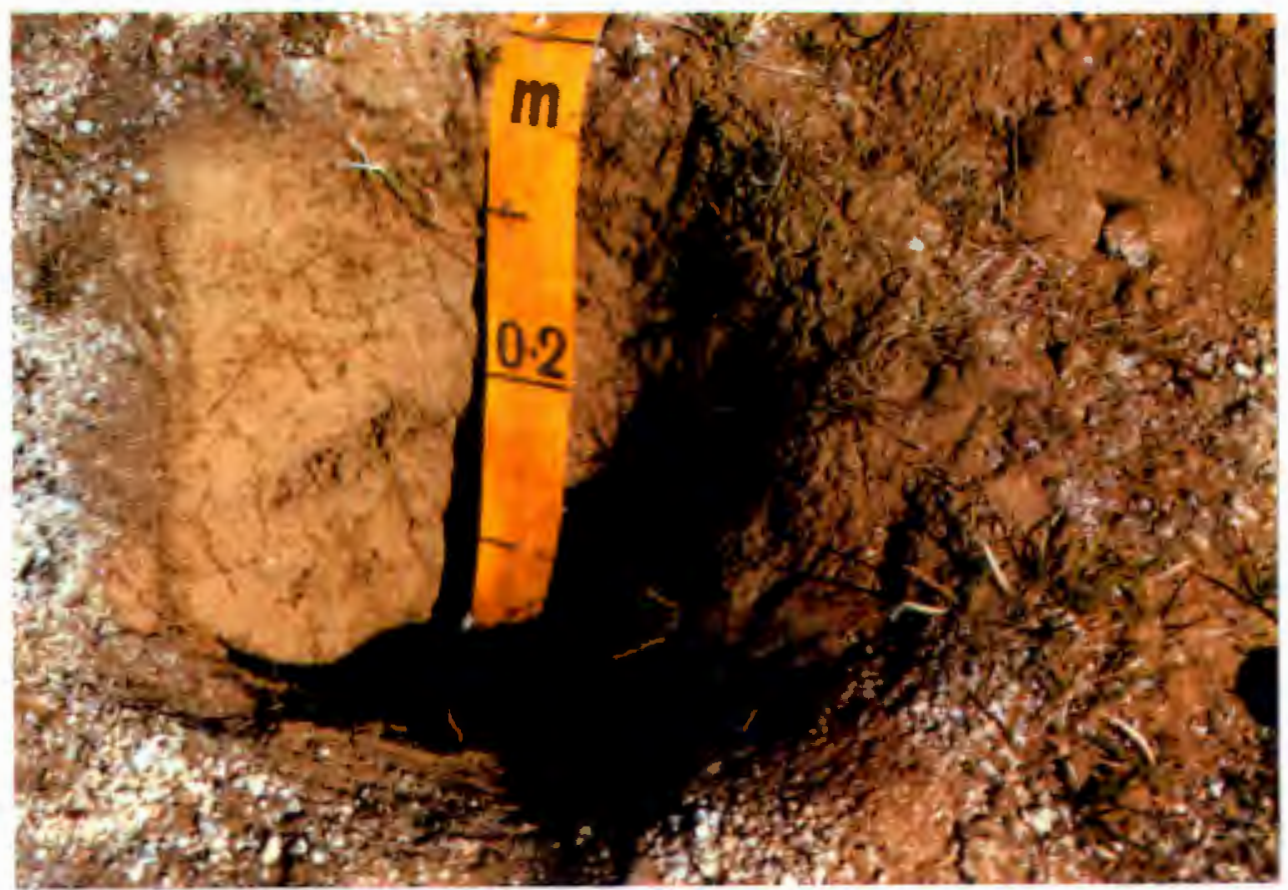

Eigure 19. Soil profile 2EC. Note fewer large rocks in profile. 


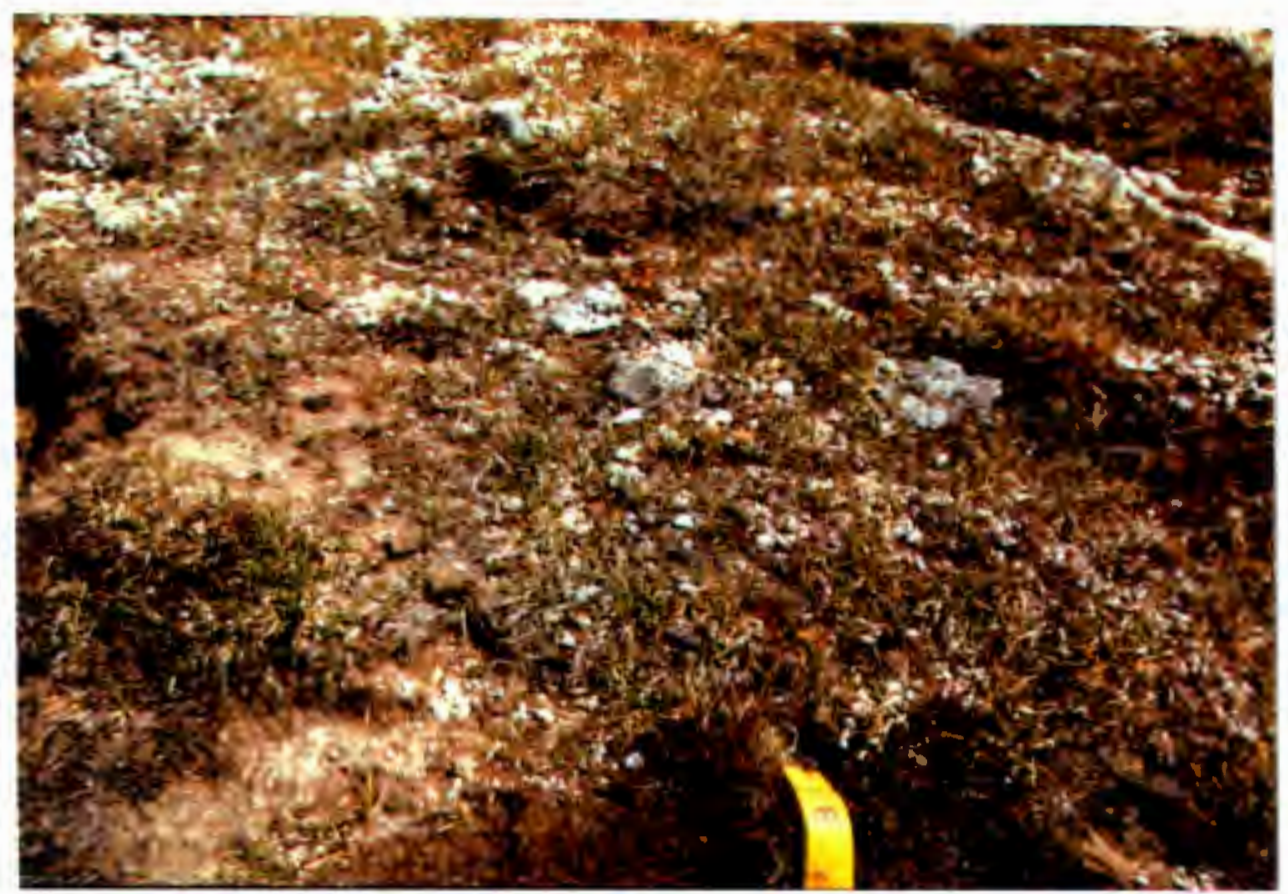

Eigure 20. Eagle Cap site of Soil Pit 3EC. Note alpine turf and change in slope gradient. Located alongside the trail.

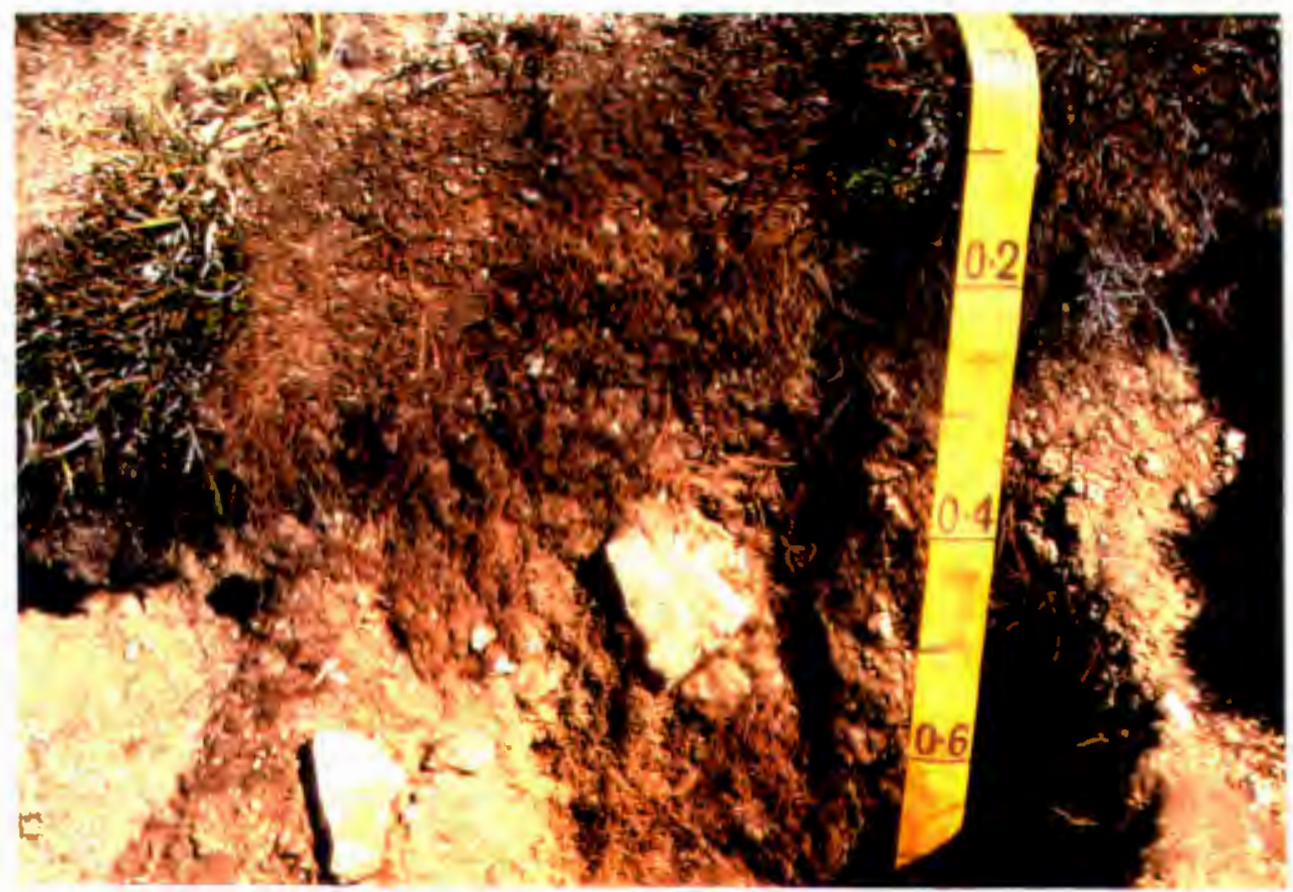

Eigure 21. Soil Profile 3EC. Note the depth of profile and high quantity of organic matter. 
Noticeable slope movement was apparent in the area in the form of partial stone stripes and surficial basalt rock fragments. The vegetation was grassy sedges, mosses and heather and provided a substantial increase in organic matter and root presence throughout the profile.

The profile displayed three A horizons overlying one, or possibly two Bw horizons (Appendix A). The Al horizon reached a depth of $10 \mathrm{~cm}$ and was identified by its very dark brown (10YR 2/2) color. The granular structure and percentage of coarser material (40\%), as well as the loamy sand texture failed to differ with depth of the A horizons. The Al horizon changed to an $A 2$ horizon at about $11 \mathrm{~cm}$, yet exhibited similar characteristics. The A2 had a very dark grayish color (10YR $3 / 2$ ) and was lighter because it was either an old E horizon (a light, minerally depleted horizon), or a depositional ash layer. Most likely this is an ash layer because it has the highest NaF pH of the three A horizons.

The $\mathrm{A} 3$ horizon, at $16 \mathrm{~cm}$, was darker (10YR 2/2) and exactly the same as the $A 1$ horizon in all field characteristics. The Bw1 horizon that occurred at a depth of $35 \mathrm{~cm}$ increased in coarser particles (50\%), including some large rocks. However it continued to be a coarse, loose, nonsticky loamy sand. The horizon did differ in color, as it was a moist dark yellowish brown (1OYR 3/4). There were also some dark marks on the rocks (organocutans) that provided evidence of organic translocation (Burns 1980). The Bw2 horizon 
occurred at $53 \mathrm{~cm}$, and exhibited such minimal development that it could be considered a $C$ horizon, especially as it was coarse (over $75 \%$ sand-sized particles), weathered parent material. The Munsell soil color for the Bw2/C horizon was dark yellowish brown (10YR 3/4). Field classification for the soil at this site proved to be a Typic Cryumbrept (cryic soil temperature, thick A horizon, low base saturation, and increased soil development).

Further downslope at the fourth site (4EC), elevation 2,829 meters, (Figure 22), the profile became shallower, reaching bedrock at about $40 \mathrm{~cm}$ (Figure 23). The notable difference here was the basalt parent material, which weathers into blocks providing less of a soil matrix. The vegetation was similar to the previous site (3EC) with sedges and chickweed. The soil pit was located on a basalt dike. Another intriguing feature at this site was the unexpected lack of burrowing animal activity. Another soil mapper in the Wallowas noted that the animals seemed to prefer the more micaceous, crystalline rocks (Bob Ottersburg personal communication 1995).

There was some horizonation in the soil profile, allowing the classification of both $A, B w$, and $C$ horizons (Appendix A). The soil coarsened with depth, changing from a sandy loam to a loamy sand, to simply sandy (50\% gravel) in the $\mathrm{C}$ horizon. The consistency remained loose and non-sticky. The A horizon was very abrupt, $9 \mathrm{~cm}$ to the $\mathrm{Bw} 1$ horizon and 


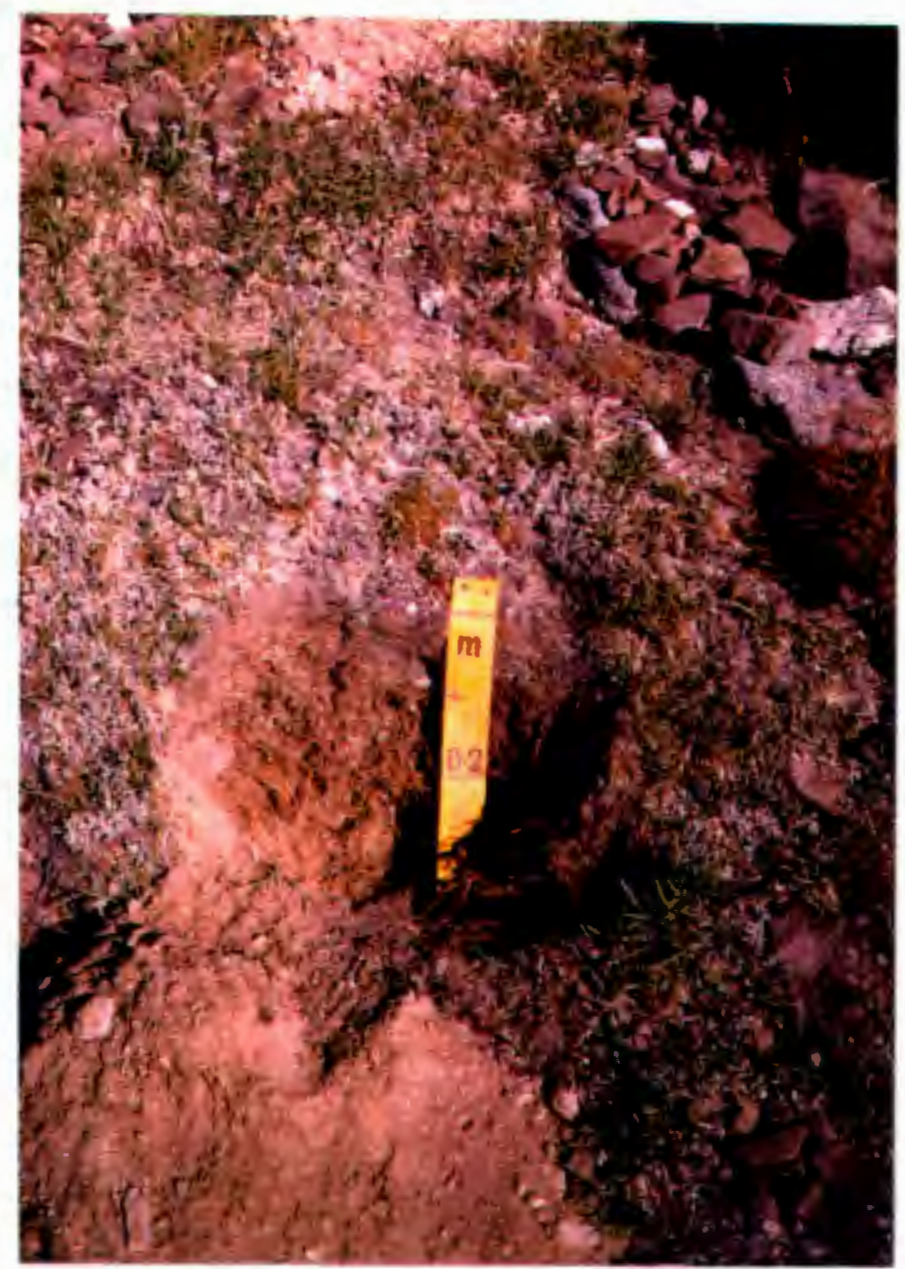

Eigure 22. Eagle Cap Site of Soil Pit 4EC. Located on the side of the trail under grasses and on basalt. 


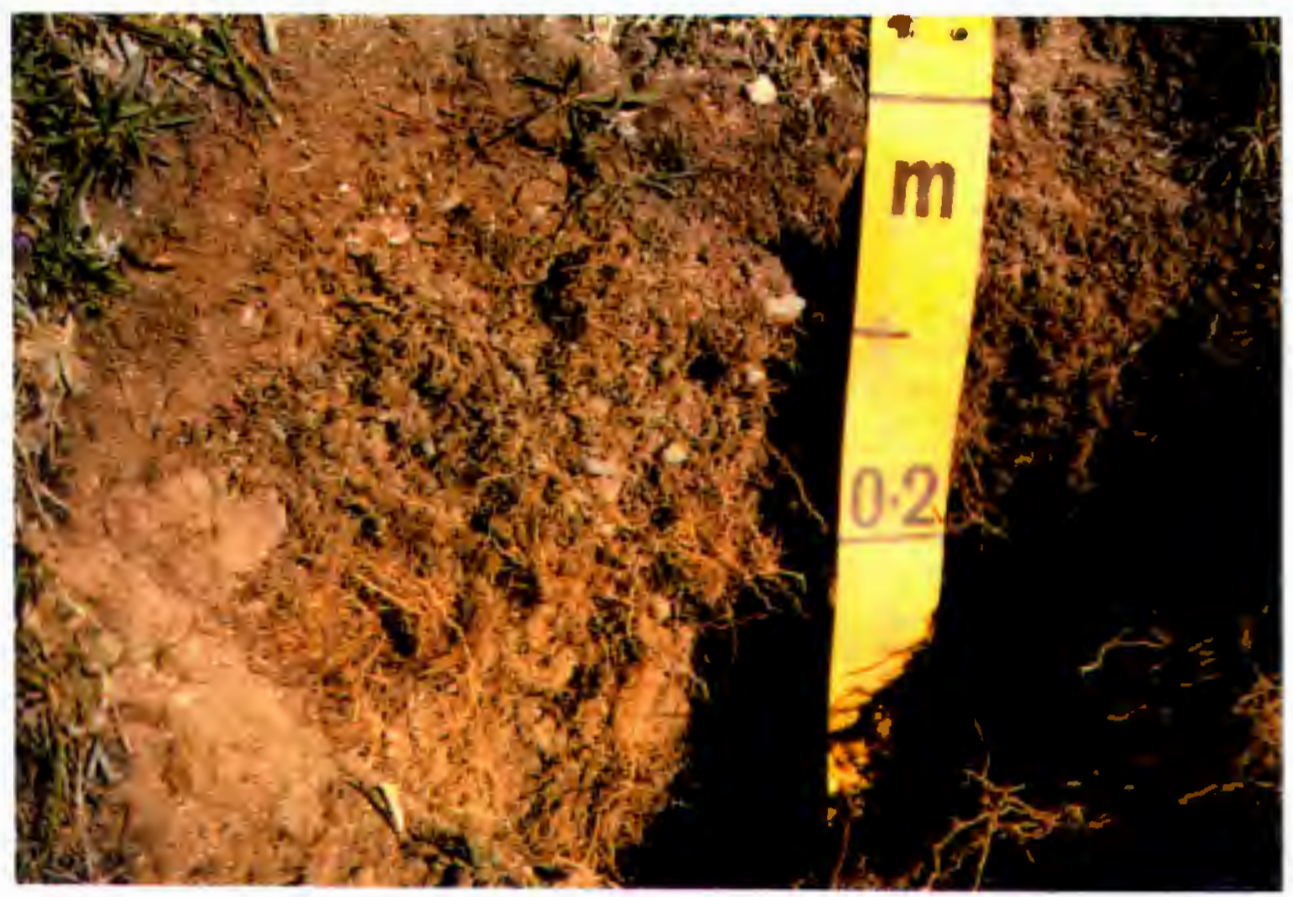

Eigure 23. Soil Profile 4EC. Note profile not as deep. 
visible due to the very dark brown color (10YR 2/2). It had a high amount of organic matter, although later lab results would indicate that it was not as great as first thought. The Bwl horizon was similar to the overlying $A$ horizon, except for the lightening of the color to a dark brown (10YR $3 / 3)$. There was a decrease with depth in organic content throughout this horizon.

The Bw2/C horizon occurred at a depth of $28 \mathrm{~cm}$ beneath a clear, wavy boundary and extended to $40 \mathrm{~cm}$ where bedrock was reached. Again this was a fairly dark yellowish brown horizon (10YR 3/4), probably due to the basaltic bedrock. The horizon was coarser in nature but was determined as being due to the lack of finer materials, not the size of residual material. However, the field classification of Lithic Dystric Cryochrept signified poorer development than the previous site, being less than $75 \mathrm{~cm}$ of mineral soil above bedrock.

The Eagle Cap catena provides a soil toposequence very similar to the Synthetic Alpine Soil Catena (Burns and Tonkin 1982; Birkeland et al. 1991). The summit soils were shallow and exhibited horizonation. However, it is believed that the soils on the summit may be related to Quaternary ice extent and were never covered, therefore providing a lengthy period for development. The soils found at lower elevations on the catena exemplify the greater depth that is typical of a lessening of the extremity of the environment, and also affected by microtopography, vegetation, translocation of 
sediments and bioturbation. The soil becomes less developed at the base of the catena, where the site was less windy, and possibly underneath a snow cover. However, the site was still within the Minimum Snow Cover (MSC) zone as vegetation remained the same, only the parent material changed. The change in bedrock to basalt may have decreased the soil development more than changes in slope angle and vegetation.

\section{Matterhorn Catena}

The detritus that developed on the Matterhorn is only loosely defined as soil, owing to its low organic content, lack of vegetation, and coarse-grained mineralogy. The rock has weathered, but seems to be simply mineral breakdown. The question that arises here is how much influence does allochtonous (transported sediment) material play in soilformation. The catena stretched from the summit of the Matterhorn, elevation 2,996 meters, to a lower level at 2,890 meters. However, there was very little soil cover at either of the two sites selected.

The Matterhorn (Figure 24) is composed of Upper Triassic marble, which is part of the Hurwal Formation (Neal 1973). It is heavily weathered and exhibits weathering pits (Price 1981: 227) as well as paleokarst. The latter feature suggests that the ice sheet extended above 2,893 meters, although the summit remained exposed as a nunatak (Carson et al. 1995). only two sites were deemed suitable to take samples of the residual soil. However, examination of the catena for 


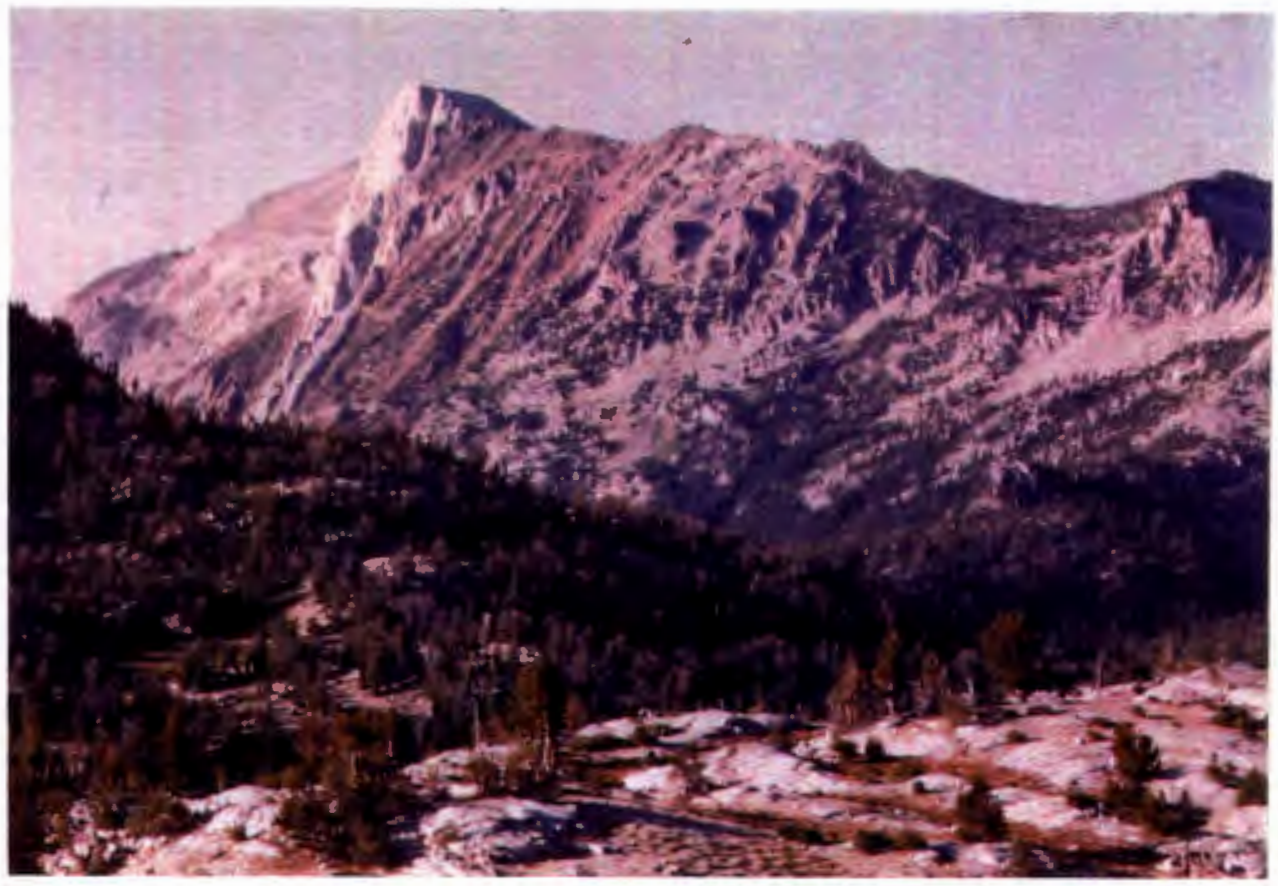

Eigure 24. The Matterhorn. Photograph taken looking north from Horton Pass. 
potential soil development was completed over its entire length. The samples collected were taken from the summit of the mountain and then the foot of the slope on a northern aspect, which would provide contrast relating to the ice cover. The terrain in-between was simply too rugged and showed little or no evidence of soil development, despite obvious weathering of the rock.

The summit of Matterhorn, like Eagle Cap, has been fairly extensively trampled by climbers (Figure 25), but a site was chosen that was less disturbed (1MH, Appendix A). The soil profile exhibited a depth of $25 \mathrm{~cm}$ to unweathered marble (Figure 26), which was tested positive with hydrochloric acid. The "soil" was characterized as having a C1 and C2 horizon with little or no development. Samples were collected at both horizons to examine in the lab how much difference there was with depth, although it was apparent that the soils were coarse, highly granular (75\% gravel), lacking horizons and very poorly developed. Not surprisingly, the texture was sandy, and there was no consistence.

The $\mathrm{C} 1$ horizon reached a depth of about $10 \mathrm{~cm}$. It was less coarse than the underlying material, which contained larger rock fragments. Although it did appear darker, the Munsell color did not change as both horizons were light brownish gray (1OYR 6/2). Laboratory tests were needed to determine whether the soil did vary with depth, or whether it was simply weathered residuum. 


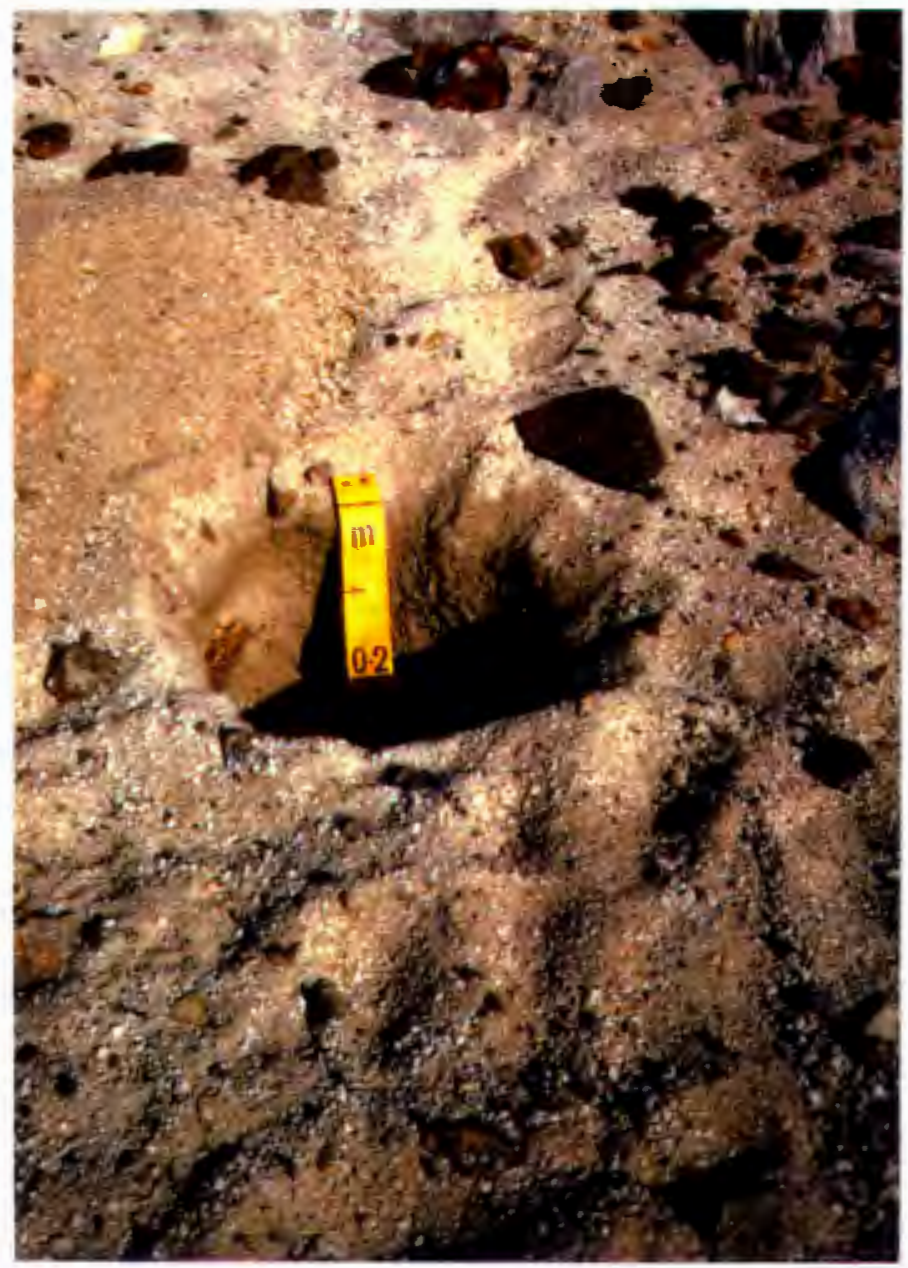

Eigure 25. Matterhorn Summit site of Soil Pit $1 \mathrm{MH}$. 


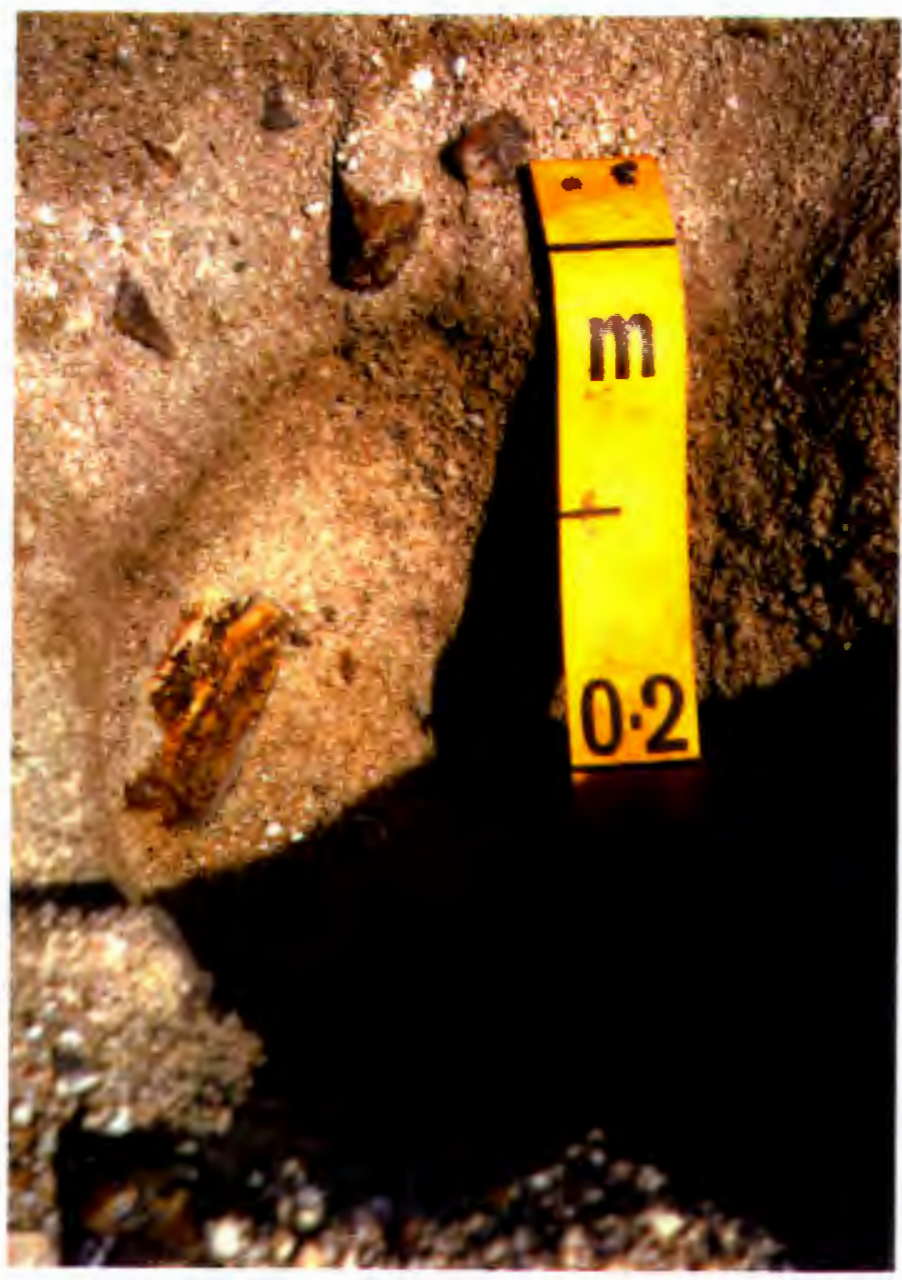

Eigure 26. Soil profile 1MH. Note coarse detritus. 
A second site proved harder to locate due to the rugged, high elevation landscape and paleokarst features from glacial meltwater action. Sediment accumulation occurred in areas of microtopography, such as small ledges, around plant roots, or where there was simply shelter from the wind. That there was very little vegetation meant that soil could not form in such areas, and there was little or no soil development.

The eventual second site ( $2 \mathrm{MH}$, Appendix A) was selected at the toe slope of the Matterhorn (Figure 27), close to the division of the Hurwal and Martin Bridge formations (Neal 1973). Nearby vegetation was predominantly alpine mat plants due to the windiness of the ridge. The "soil" reached a depth of $30 \mathrm{~cm}$, although below $10 \mathrm{~cm}$ it was almost entirely weathered parent material (Figure 28). The color did vary, creating a distinction between the top and the bottom of the soil pit. However, the composition was coarse marble particles (50 to 75\%) with no structure, and the particles were loose, sandy weathered materials. The color of the lower (C2) horizon was dark gray (2.5Y 1/1), whereas the surficial material (C1) was dark olive gray (2.5Y 5/2), possibly signifying a substantial quantity of eolian material in the soil profile.

The lack of soil development on the Matterhorn is mostly related to the severity of the environment. There are few factors that preempt soil development, as the summit lacks vegetation, is extremely windy, and steep. However, there was 


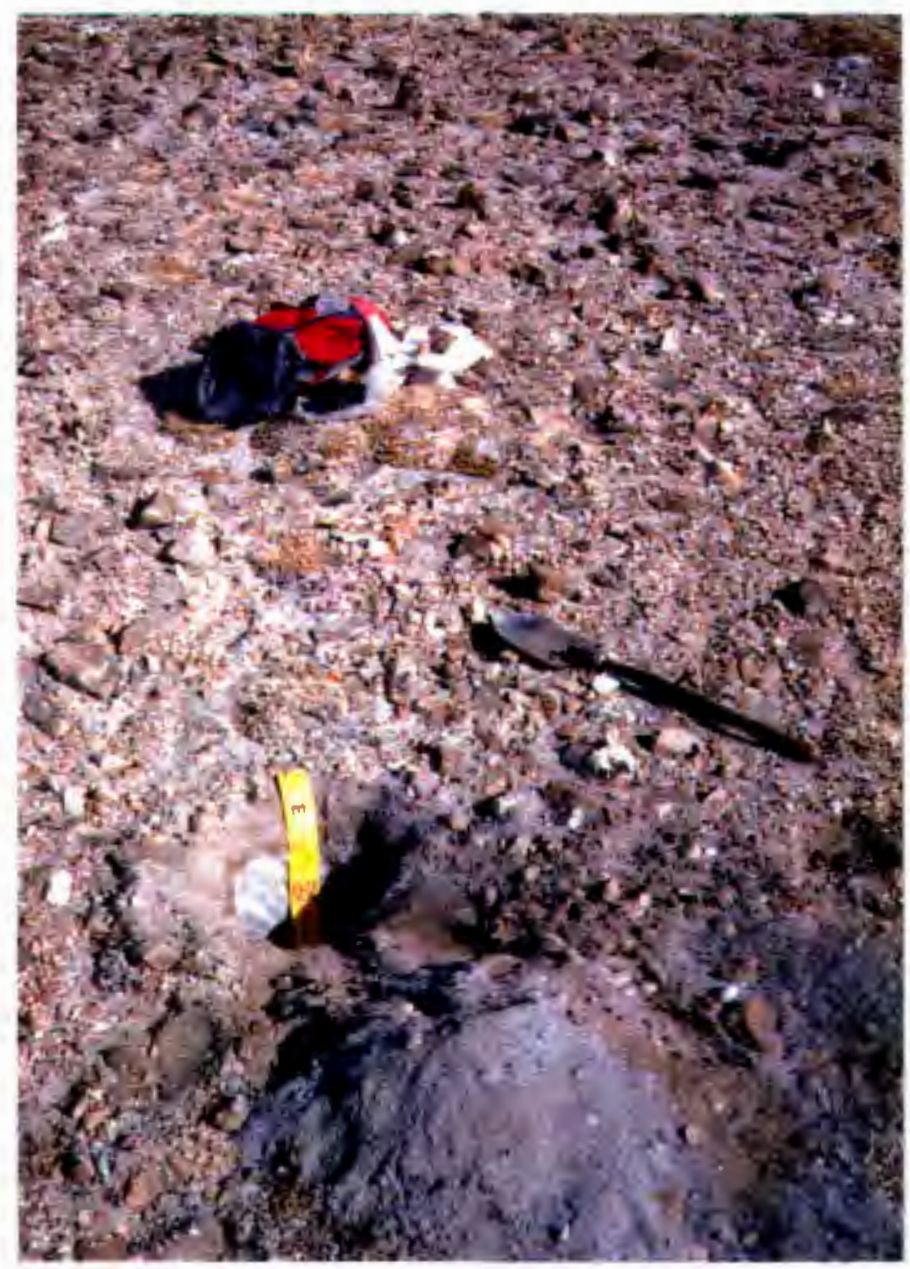

Figure 27. Matterhorn site of Soil Pit 2MH. Note alpine mat plants and coarse rock fragments. 


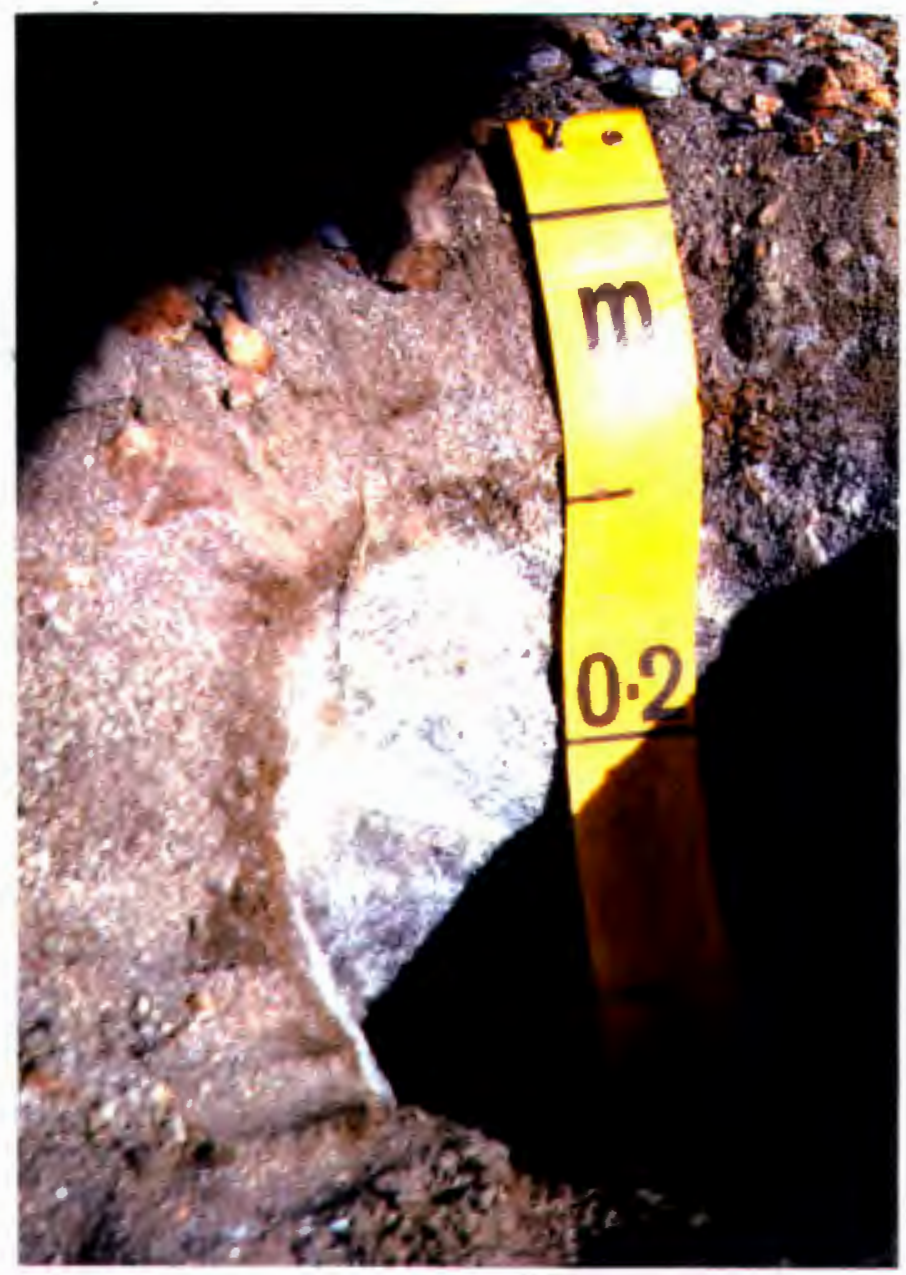

Figure 28. Soil profile $2 \mathrm{MH}$. Note the saprolitic nature of the C2 horizon and eolian fines visible in C1 horizon. 
a noticeable influence of allochtonous materials that might affect future soil development. The second site, at the toe slope, also exhibited a lack of development. Despite some finer materials, and organic presence, the lack of development was more likely due to the site being beneath the level of Quaternary ice cover and on an extremely windy ridge.

\section{Sacajawea Summit}

Sacajawea is the highest peak in the Wallowas at 2,999 meters. The summit is a narrow ridge composed of Triassic metamorphic rocks, such as shale, slate, phyllite and mudstone. Sacajawea is considered part of the Martin Bridge Formation and is separated from the Matterhorn by an extensive and treacherous arete (Figure 29) (Neal 1973). There is little to no soil cover, although there is some evidence for the beginning of soil development. The soil development is due to the presence of eolian fines, and a horizon where the soil is darker in color.

The soil at the summit of Sacajawea was fairly shallow, however, and only one site (SA, appendix A) was possible since the area was quite narrow (Figure 30 ). The soil pit that was selected was at the south end of the peak. Bedrock was reached at a depth of $15 \mathrm{~cm}$, which while not very deep, was interesting in that the soil was composed of finer sediments (Figure 31). Samples were collected so as to 


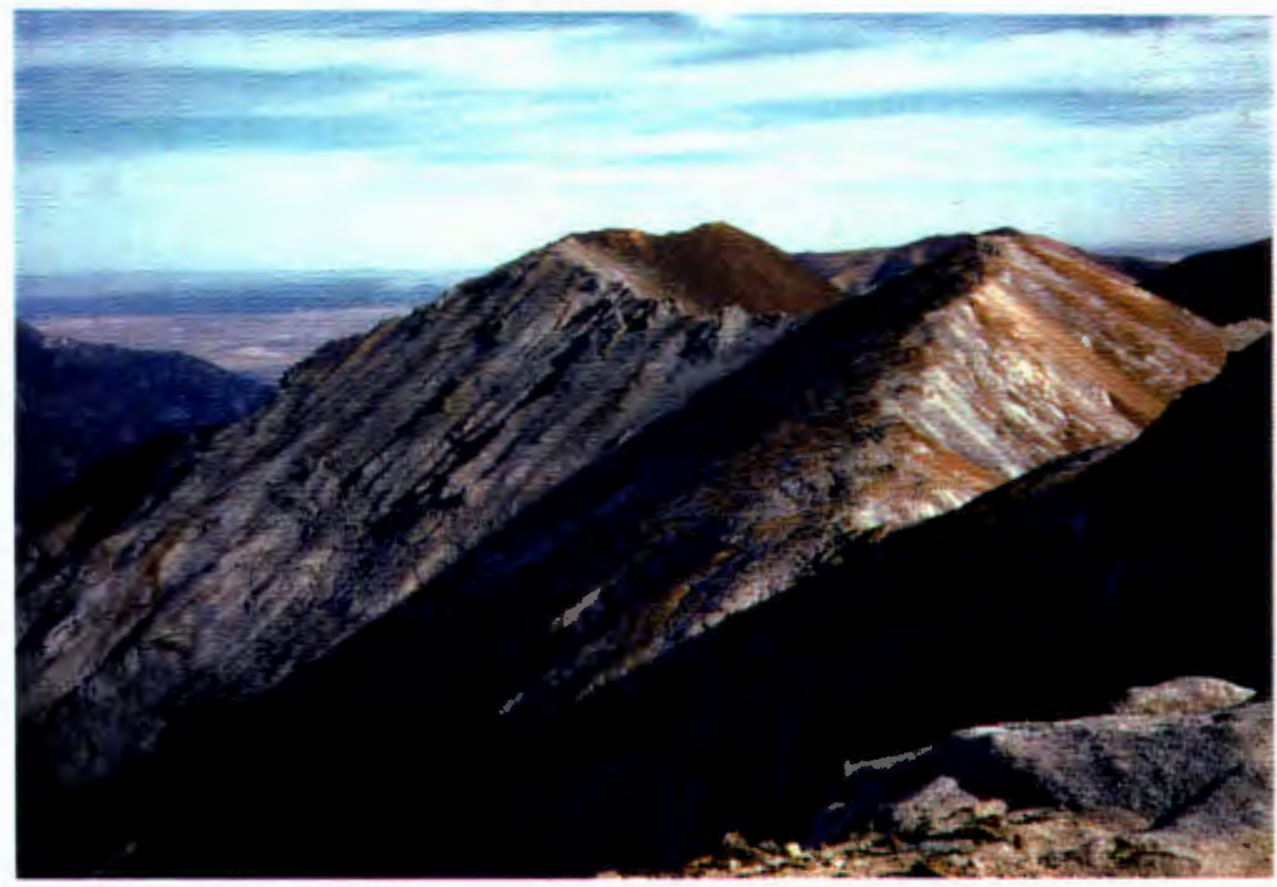

Eigure 29. Sacajawea (end of arete in distance, looking north). Photograph taken from the summit of Matterhorn. 


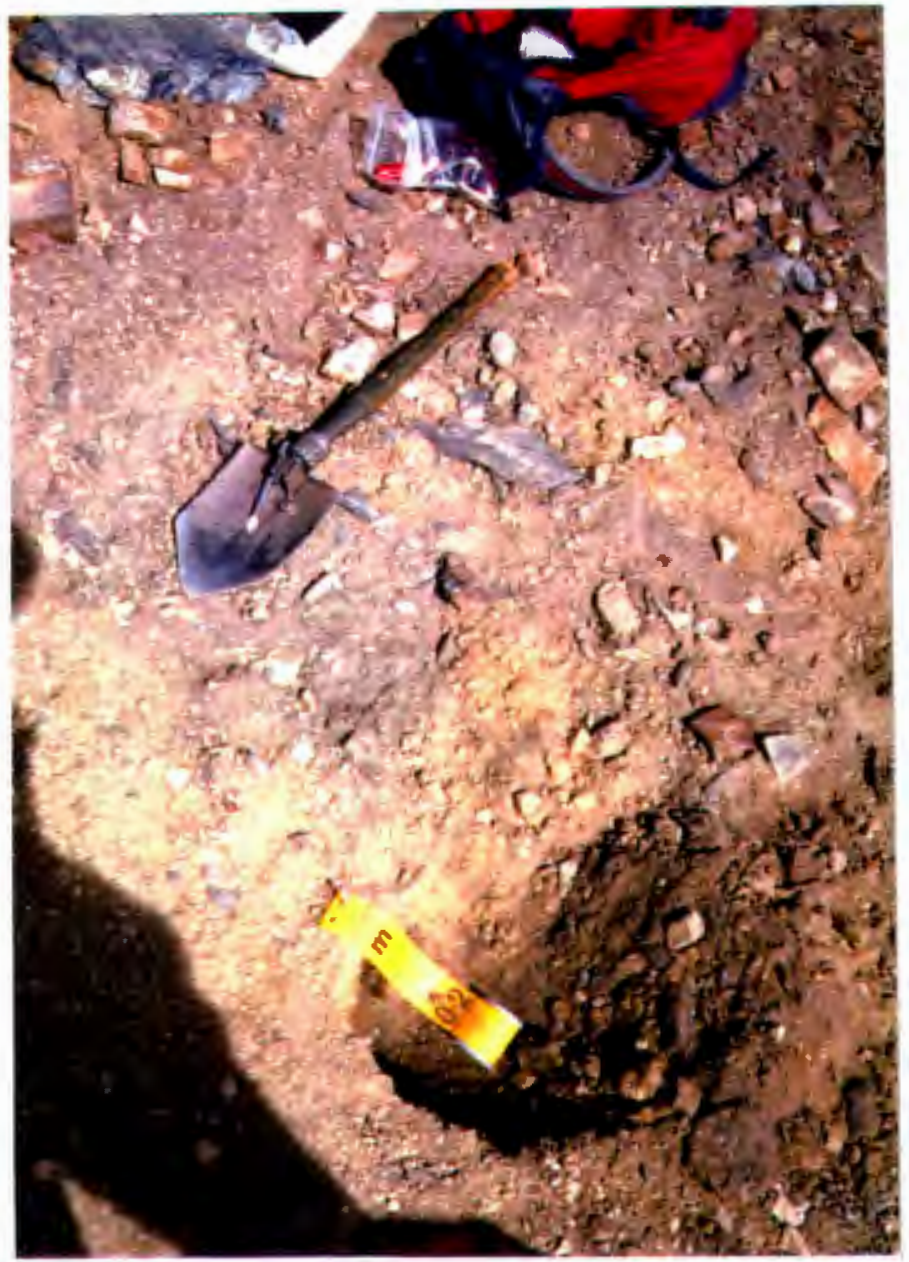

Figure 30 . Sacajawea Summit Site of Soil Pit SA. 


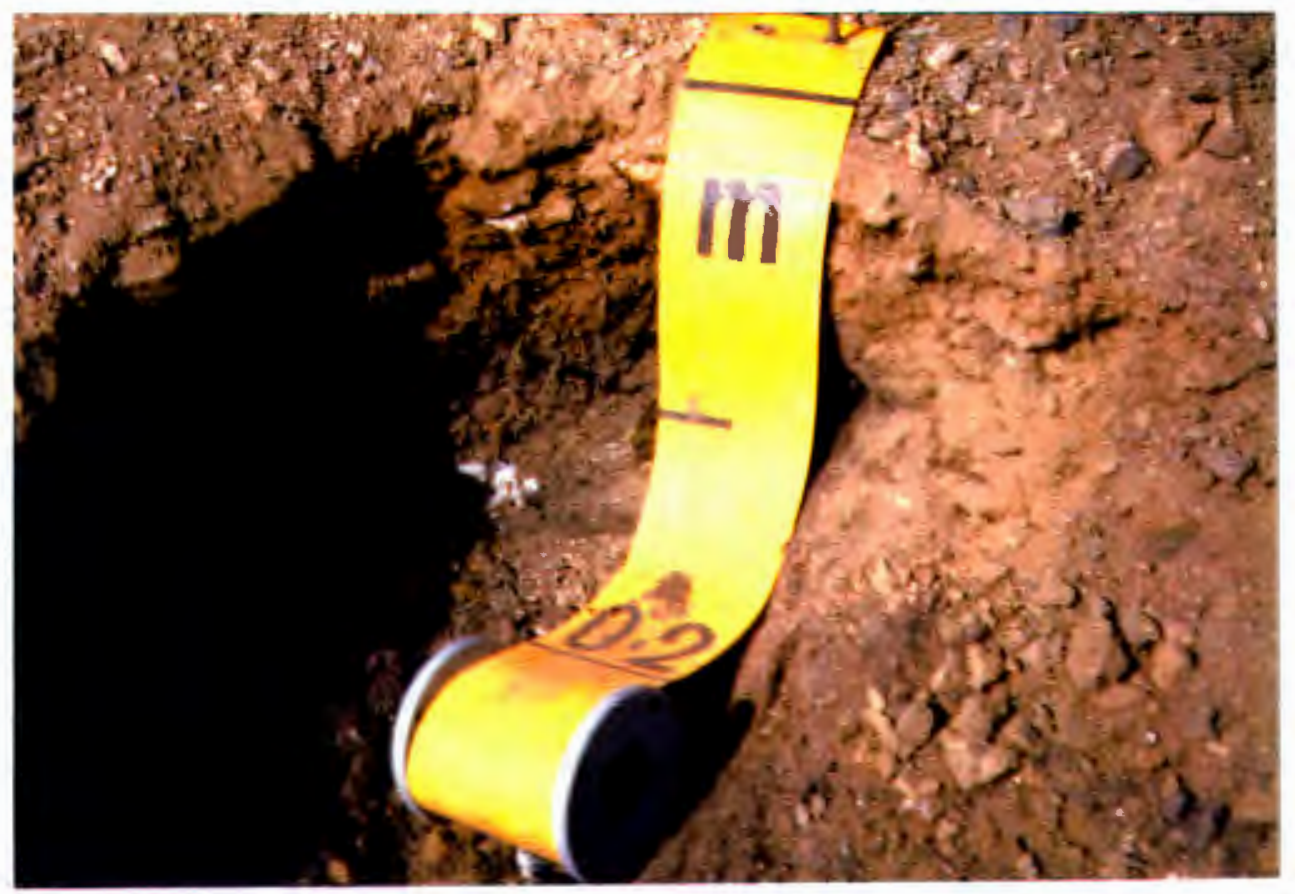

Figure 31. Soil Profile SA. Shallow soil profile. Note the darker layers, possible buried horizon. 
examine the differences in the profile that indicated a possible buried horizon.

The soil was classified as having a C1 and C2 horizon overlying a C3 horizon. The C1 horizon was very thin, only 2 $\mathrm{cm}$ at most and was apparently coarser than the underlying $\mathrm{C} 2$ horizon. However, it was still a fairly fine, windblown, loamy sand. The horizon was dark brown (10YR 3/3). The C2 horizon provided a much finer horizon. It ranged from 2 to 10 $\mathrm{cm}$ and was a fine loam texture with less than $10 \%$ sand size particles. This horizon was slightly plastic, unlike the other non-sticky and loose C1 and C3 horizons. The color when tested was slightly lighter despite the appearance. It was a dark yellowish brown (10YR 3/4) color.

The C3 horizon was slightly coarser and of a significantly looser consistence. It still contained fairly fine, granular sediments but was darker than the overlying horizon. The Munsell color was a very dark brown (10YR2/2) color.

It was apparent from a simple field investigation that the soils developing on Sacajawea were predominantly eolian materials. They were afforded a C2 horizon classification for the simple reason that the soils were affected by the continual input of eolian materials. Eventually, this may develop into a soil. 
LABORATORY SOIL PROPERTIES

Five main tests were conducted on the soil samples: particle size analysis, $1: 1$ water and $2: 1 \mathrm{pH} \mathrm{CaCl}_{2}$, sodium fluoride (NaF) pH (test for allophane, volcanic ash), organic carbon content, and silt mineralogy. Appendix A contains a thorough account of the all the soil properties, while laboratory properties are listed in this section. The chapter concludes with a discussion of the classification of the soils.

\section{Particle Size Analysis}

Eagle Cap provides the most extensive site to examine the variation in particle size for each soil. A significant feature about the summit soils (1EC) was that despite the coarse texture of the soil, there was evidence of finer particle translocation (Table 1 ). While $93.5 \%$ of the A horizon soil (1EC1) was sand size or larger, readings decreased to $88 \%$ in the BW horizon (1EC2), and only $86.5 \%$ was that coarse in the Cox horizon (1EC3) (Table 1). Inversely, the Cox horizon contained $13.5 \%$ of material that was siltsize or finer, compared to the Bw horizon's 12\%, and the A horizon's $6.5 \%$. Further proof for finer sediments at depth was provided by graphic mean readings from the Cumulative Frequency Curves (Appendix B) of $-1.25 \varnothing$ for the $A$ horizon and $-1.75 \varnothing$ for the Cox horizon. Although this signifies a large quantity of fines in the lower horizon, and coarser grains in 
TABLE I

SEDIMENT CHARACTERIZATION

\begin{tabular}{|c|c|c|c|c|c|c|c|c|c|c|}
\hline \multirow[t]{2}{*}{$\begin{array}{c}\text { Soil } \\
\text { Sample }\end{array}$} & \multirow{2}{*}{$\begin{array}{c}\text { Depth } \\
\mathrm{cm} \\
\end{array}$} & \multirow[t]{2}{*}{ Texture } & \multirow[t]{2}{*}{$8>2 \mathrm{~mm}$} & \multirow[t]{2}{*}{ \& S and } & \multirow[t]{2}{*}{ osilt } & \multirow[t]{2}{*}{ 8Clay } & \multicolumn{2}{|c|}{$\begin{array}{c}\text { Graphic } \\
\text { Mean }\end{array}$} & \multicolumn{2}{|c|}{ Mode } \\
\hline & & & & & & & $\varnothing$ & $\mathrm{mm}$ & $\varnothing$ & $\mathrm{mm}$ \\
\hline $1 \mathrm{MH} 1$ & $0-10$ & Sandy & 17 & 80 & 1 & 1 & -0.5 & 1.4 & -0.5 & 1.4 \\
\hline $1 \mathrm{MH} 2$ & $10-25$ & Sandy & 21 & 78 & 1 & 0 & -1.25 & 2.4 & 0.5 & 0.7 \\
\hline 2MH 1 & $0-10$ & Sandy & 3 & 80 & 15 & 2 & 0.75 & 0.6 & 0.5 & 0.7 \\
\hline $2 \mathrm{MH} 2$ & $10-30$ & Sandy & 4 & 93 & 1 & 3 & 0.5 & 0.7 & 0.75 & 0.6 \\
\hline SAl & $0-2$ & Loamy Sand & 25 & 55 & 14 & 6 & -0.75 & 1.8 & 3.0 & 0.1 \\
\hline $\mathrm{SA} 2$ & $2-10$ & clay & 33 & 49 & 14 & 4 & -1.25 & 2.6 & 0.75 & 0.6 \\
\hline SA3 & $10-15$ & Loamy Sand & 51 & 35 & 11 & 3 & -2.25 & 4.7 & -4.6 & 25.0 \\
\hline $1 \mathrm{EC} 1$ & $0-2$ & Loamy Sand & 30 & 64 & 5 & 2 & -1.25 & 2.5 & -0.5 & 1.4 \\
\hline $1 \mathrm{EC} 2$ & $2-8$ & Loamy Sand & 25 & 63 & 10 & 2 & -1.0 & 2.1 & -0.5 & 1.4 \\
\hline $1 \mathrm{EC} 3$ & $8-45$ & Sandy & 32 & 54 & 11 & 3 & -1.75 & 3.3 & -0.5 & 1.4 \\
\hline $3 \mathrm{EC1}$ & $1-10$ & Loamy Sand & 22 & 73 & 4 & 2 & -0.5 & 1.3 & -0.5 & 1.4 \\
\hline $3 \mathrm{EC} 2$ & $10-16$ & Loamy Sand & 19 & 76 & 3 & 2 & -0.25 & 1.3 & 0.75 & 0.6 \\
\hline 3EC3 & $16-35$ & Loamy Sand & 34 & 62 & 3 & 1 & -1.75 & 3.3 & 0.75 & 0.6 \\
\hline 3EC 4 & $35-52$ & Loamy Sand & 31 & 59 & 9 & 2 & -1.25 & 2.5 & 0.75 & 0.6 \\
\hline $3 E C 5$ & $52-85$ & Sandy & 41 & 52 & 6 & 2 & -2.25 & 4.5 & -0.5 & 1.4 \\
\hline $4 \mathrm{EC1}$ & $0-9$ & Sandy Loam & 6 & 87 & 5 & 2 & 1.0 & 0.5 & 2.5 & 0.2 \\
\hline $4 \mathrm{EC} 2$ & $10-28$ & Loamy Sand & 29 & 67 & 3 & 2 & -1.25 & 2.2 & -0.5 & 1.4 \\
\hline $4 \mathrm{EC} 3$ & $28-40$ & Sandy & 39 & 54 & 6 & 2 & -1.75 & 3.2 & -0.5 & 1.4 \\
\hline
\end{tabular}

Notes: Matterhorn (MH), Sacajawea (SA), Eagle Cap (EC). Example 1MH1 (site \#1, Matterhorn, sample \#1). All particle size numbers rounded to the nearest whole number (may not add up to 1008). 
the upper levels, the mode phi size was $-0.5 \phi$ throughout the soil profile. Furthermore, the standard deviation, using criteria provided by Lewis (1984: 75) (Table 2) and cumulative frequency curves (Appendix B) signified that the soils were very poorly sorted $(>2 \varnothing)$ (Table 3 ).

No samples were taken at the second site along the Eagle Cap catena, and so the soil was not tested for various particle sizes. The particle size tests for the soil from the third site ( $3 E C)$, though, displayed a noticeable decrease in silt and clay sediment percentage, the maximum being found in the BwI horizon (3EC4) at $10 \%$ (Table 1). However, this horizon was the sole exception, as the upper $3 \mathrm{~A}$ horizons contained less than $5.5 \%$ silt and clay sediments. The coarsest particles were present in the A3 horizon (3EC3), with $96 \%$ being sand size or greater. This horizon also had the lowest fines for the site at only $4 \%$ (Table 1 ). However, while particle size seemed to decrease with depth, the graphic mean showed that this was not the case, and the largest particles were in the Bw2/C horizon (-2.25ф) although, the particle size for the Bwl horizon was smaller than the overlying $A 3$ horizon. Once more, the standard deviation exhibited a very poorly sorted soil profile that had a wide range of phi sizes (Table 3 ).

The final soil sample from the Eagle Cap catena (4EC) also showed fairly low percentage of fine sediments. However, the A horizon ( $4 \mathrm{EC} 1$ ) despite being coarse, contained 
TABLE II

\section{SORTING ACCORDING TO STANDARD DEVIATION AND PHI SIZE (Lewis 1984: 75).}

\begin{tabular}{cc}
\hline phi size $(\varnothing)$ & sorting \\
\hline$<0.35 \varnothing$ & very well sorted \\
0.35 to $0.50 \varnothing$ & well sorted \\
0.50 to $0.71 \varnothing$ & moderately well sorted \\
0.71 to $1.0 \varnothing$ & moderately sorted \\
1.0 to $2.0 \varnothing$ & poorly sorted \\
2.0 to $4.0 \varnothing$ & very poorly sorted \\
$>4.0 \varnothing$ & extremely poorly sorted \\
\hline
\end{tabular}

TABLE III

STANDARD DEVIATION \& SORTING

\begin{tabular}{|c|c|c|c|}
\hline Sample & $\begin{array}{l}\text { standard } \\
\varnothing\end{array}$ & $\begin{array}{r}\text { Deviation } \\
\mathrm{mm}\end{array}$ & sorting \\
\hline $1 \mathrm{MH} 1$ & 1.4 & 0.4 & ps \\
\hline $1 \mathrm{MH} 2$ & 2.6 & 0.2 & vps \\
\hline $2 \mathrm{MH} 1$ & 1.3 & 0.4 & ps \\
\hline $2 \mathrm{MH} 2$ & 1.0 & 0.5 & $\mathrm{~ms}$ \\
\hline SA1 & 3.6 & 0.1 & vps \\
\hline SA2 & 3.5 & 0.1 & vps \\
\hline SA3 & 3.6 & 0.1 & vps \\
\hline $1 E C 1$ & 2.6 & 0.2 & vps \\
\hline $1 \mathrm{EC} 2$ & 2.4 & 0.2 & vps \\
\hline $1 \mathrm{EC} 3$ & 3.5 & 0.1 & vps \\
\hline $3 E C 1$ & 2.3 & 0.2 & vps \\
\hline $3 \mathrm{EC} 2$ & 2.3 & 0.2 & vps \\
\hline $3 \mathrm{EC} 3$ & 2.8 & 0.1 & vps \\
\hline $3 E C 4$ & 2.7 & 0.2 & vps \\
\hline $3 \mathrm{EC} 5$ & 3.0 & 0.1 & vps \\
\hline $4 \mathrm{EC} 1$ & 1.9 & 0.3 & ps \\
\hline $4 \mathrm{EC} 2$ & 2.5 & 0.2 & vps \\
\hline $4 \mathrm{EC} 3$ & 2.8 & 0.1 & vps \\
\hline
\end{tabular}


predominantly sandy particles (86.6\%) (Table 1). This surely allowed for an influx of finer material and was noticeable in the profile as a $7 \%$ A horizon content and a significant amount translocated to the $C$ horizon (7\%). The Bw horizon (4EC3) displayed a larger quantity of coarser grains (95.5\%), yet had a graphic mean of $-1.25 \phi$, which was smaller than the $C$ horizon $(-1.75 \phi)$ (Table 1 ). The variation in the soil sample particle size is best explained by the very poor sorting in the profile, which again resulted from movement of the finer sediments throughout the soil (Table 3 ).

Unlike Eagle Cap, the Matterhorn soils are very poorly developed. Field tests had already shown there to be an influx of finer material. However, particle size analysis showed this to be no greater than $2.35 \%$ in the upper reaches of the soil (1MHI) and only 18 with depth (Table 1). Despite the open matrix, it is apparent that very little has been translocated. The lower level (1MH2) is naturally coarser, containing $99 \%$ particles greater than sand size, although this is substantiated by a greater percentage, $20.9 \%$, of the sample greater than $2 \mathrm{~mm}$ (Table 1 ). The finer sediment in the surface horizon is reflected by a mean phi reading of $-0.5 \varnothing$ compared to $-1.25 \phi$ in the lower level, meaning that much of the finer sediment in the Matterhorn summit soils remains at the surface or is blown away.

Samples from the lower toe slope site on the Matterhorn (2MH), show a marked increase in the amount of silt and clay 
sized particles. The upper level of the soil (2MH1), exhibit $17 \%$ finer particles, with 15\% of those silt-size (Table 1). Undoubtedly this is due to eolian deposition. The lower part of the soil (2MH2) does not contain as much, only $3 \%$, although $2.5 \%$ of the finer sediment is clay size (Table 1 ). Both of the samples are mostly coarse grained, however, and weathering has been significant enough to reduce the quantities of particles greater than $2 \mathrm{~mm}$, with readings of only $3.1 \%$ and $4.1 \%$ with depth (Table 1). A noticeable difference in the graphic mean at this site proved that indeed the particles are finer than the soils on the Matterhorn summit, averaging $0.5 \phi$ and $0.8 \phi$, the smaller phi size nearer the surface. The surface is considered moderately sorted, a fact explained by predominance of allochtonous materials (eolian sediments) and lack of residual component to the soil. While still not developed enough to be called a "soil," the indications are that this site is more developed than the summit.

Sacajawea's summit soil was the final sample to undergo particle size testing. The difference in horizons with depth that was noticed in the field was not as significant here; however, but there is still a large silt component. This is $14 \%$ in the upper 2 horizons, and $11 \%$ at the base of the soil (SA3) (Table 1). Similarly, the clay component is fairly high at $6 \%$ on the surface (SA1). The explanation for this again is the influence of eolian sediments, although all three samples 
have high percentages of coarser particles $180 \%, 82 \%$, and 86.5\%). The mean and mode phi sizes also display a greater particle size with depth, ranging from $-0.75 \varnothing$ to $-2.25 \varnothing$ graphic mean, and $3 \phi$ to $-4.6 \varnothing$ mode (Table 3 ). The $3 \phi$ for the mode size of the upper horizon supports the influence of eolian matter in pedogenesis.

The particle size analysis shows that for the most part, the soil samples collected in the wallowas were coarsegrained (gravel and sands). Most of them contained $50 \%$ or more sand-sized particles. In the case of the Matterhorn soils, the soil sand particle size reached $92 \%$ with silts and clays making up barely $2 \%$ of the sediment present. Higher quantities of silt and clay in each soil are minimal, although the greatest amounts, $14 \%$ (silt) and $6 \%$ (clay) found on Sacajawea, suggest that the eolian component plays more of a part in pedogenesis at the site. Even so, Sacajawea still maintains a fairly high quantity (over 75\%) of greater than sand-size particles (Table 1 ).

Eagle Cap was fairly consistent throughout, although the finer sediments were noticeably less on the shallower soils, and those on basaltic bedrock. The development on the catena exhibited a slightly different profile to the synthetic Alpine Slope (Burns and Tonkin 1982), as the particle size content signified less of a development (affecting horizon classification). The fine-grained (usually eolian layer) surface horizons found in other alpine areas (Burns 1980) 
were absent, meaning the eolian sediments are being washed into the soil matrix. Therefore, the eolian dusts are unable to accumulate on the surface.

\section{SOII $\mathrm{pH}$}

Three $\mathrm{pH}$ tests were performed on the soil samples to determine the acidity, organic influence and ash content. A 1:1 pH water test was used to determine the acidity of the soil, while the $2: 1 \mathrm{CaCl}_{2} \mathrm{pH}$ method reflects base saturation and also provides field conditions of soil with plant/microorganism contact, as well as minimizing the liquid junction potential (Black 1965: 918). This provides an indicator of the influence of organic matter on the soil pH, therefore the $2: 1 \mathrm{CaCl}_{2} \mathrm{pH}$ readings are expected to be lower than the $1: 1 \mathrm{pH}$.

The Eagle Cap soils exhibit little variation between sites, and each profile displays an increase in pH with depth (Table 4). The summit samples increase from 6.7 (1EC1) to 7.2 (1EC3), with the lower reading from the surface sample no doubt owing to the influence of the vegetation (Table 4). The 2:1 tests for organic influence however, show little change in the sample from the A horizon, as pH decreases from 6.6 to 6.5. However, change was visible in the other samples which both had a reading of 6.6 (Table 4). This signifies the presence of some organic matter with depth, a fact testified by field results. 
TABLE IV

SOIL PH RESULTS ( $1: 1$ WATER AND $\left.2: 1 \quad \mathrm{CaCl}_{2}\right)$

\begin{tabular}{|c|c|c|c|c|c|}
\hline soil & Sample & DH & (water) & $\mathrm{pH}$ & $2: 1 \quad\left(\mathrm{CaCl}_{2}\right)$ \\
\hline & $1 \mathrm{MH} 1$ & & 7.3 & & 5.8 \\
\hline & 1MH2 & & 7.1 & & 6.1 \\
\hline & $2 \mathrm{MH} 1$ & & 6.7 & & 6.5 \\
\hline & $2 \mathrm{MH} 2$ & & 6.8 & & 6.5 \\
\hline & SA1 & & 6.8 & & 6.6 \\
\hline & SA2 & & 6.7 & & 6.6 \\
\hline & SA3 & & 7.1 & & 6.6 \\
\hline & $1 \mathrm{EC} 1$ & & 6.7 & & 6.5 \\
\hline & $1 \mathrm{EC} 2$ & & 6.9 & & 6.6 \\
\hline & $1 \mathrm{EC} 3$ & & 7.2 & & 6.6 \\
\hline & $3 E C 1$ & & 6.5 & & 6.1 \\
\hline & $3 \mathrm{EC} 2$ & & 6.6 & & 6.1 \\
\hline & $3 \mathrm{EC} 3$ & & 6.6 & & 6.2 \\
\hline & $3 E C 4$ & & 6.9 & & 6.3 \\
\hline & $3 E C 5$ & & 7.3 & & 6.4 \\
\hline & $4 \mathrm{EC} 1$ & & 6.2 & & 6.0 \\
\hline & $4 \mathrm{EC} 2$ & & 6.6 & & 6.2 \\
\hline & $4 \mathrm{EC} 3$ & & 7.2 & & 6.4 \\
\hline
\end{tabular}

Notes: Matterhorn (MH), Sacajawea (SA), Eagle Cap (EC). 
The $\mathrm{pH}$ readings from the $3 \mathrm{EC}$ site exhibit a natural decrease with depth of sample (Table 4). The samples have a lower pH near the surface in 3EC1 (6.5), increasing with depth to 6.9 in the Bw1 sample (3EC4) and 7.3 in the Bw2/C (3EC5) sample. This decrease in acidity with depth is a result of less organic influence and is reflected in the 2:1 pH test.

However, the 2:1 $\mathrm{CaCl}_{2}$ test did show some change throughout the soil profile, as the 3 ECI sample decreased to 6.1 and the 3 EC5 sample to 6.4 (Table 4). More apparent in these samples is the increase in organic influence moving downslope.

The final soil samples ( $4 \mathrm{EC}$ ) from Eagle Cap also displayed an increasing $\mathrm{pH}$ with depth for both the $1: 1$ and $2: 1 \mathrm{pH}$ tests (Table 4). Not surprisingly, an increase in organic matter throughout the soil samples provided $2: 1 \mathrm{pH}$ readings of $6.0(4 \mathrm{EC} 1), 6.2$ (4EC2), and 6.4 (4EC3) respectively (Table 4), with the lowest of these naturally being located in the $A$ horizon. The $1: 1$ water readings gave the lowest $\mathrm{pH}(6.2)$ of any of the sites, as well as providing the biggest difference between $A$ and the lowest horizon, Bw2/C (6.2 to 7.2$)$ (Table 4).

The Matterhorn sites exhibited higher pH's than Eagle Cap, because of the marble bedrock which dictates a more alkaline $\mathrm{pH}$. The summit of the Matterhorn had a high $1: 1 \mathrm{pH}$ reading in both samples $(7.3$ and 7.1 ) (Table 4 ). However, the 
readings unexpectedly dropped to 5.8 and 6.1 respectively after the $2: 1 \mathrm{pH}$ test, which would signify substantial influence of organics. The suggested influence of organic matter here would require later testing by the dichromate method. The organic influence was not witnessed at the lower site, where the soil samples drop with the $2: 1 \mathrm{pH}$, but only slightly from 6.7 (2MH1) and 6.8 (2MH2) to 6.5 for both of them (Table 4).

The soil samples from Sacajawea's summit (Table 4), while all differing in the $1: 1 \mathrm{pH}$ reading are all $6.6 \mathrm{pH}$ 's with the $2: 1$ test. The interesting $\mathrm{pH}$ reading from these samples was the second sample (SA2) though (Table 4). However, no real explanation is afforded for the $6.7 \mathrm{pH}$ as it is so close to 6.8 from the upper soil sample. Instead the soil is determined to be fairly uniform.

The overall importance of the $1: 1$ and $2: 1$ tests is displayed by Eagle Cap, whose pH values are very high for alpine soils on granodiorite. This is because the carbonate loess in the soil is raising the $\mathrm{pH}$ of the soils, and might also reflect the influence of volcanic ash. Despite the importance of the $1: 1$ and $2: 1 \mathrm{pH}$ tests, the most important soil $\mathrm{pH}$ test was the sodium fluoride $\mathrm{pH}$, a test for amorphous aluminum. Table 5 provides the readings for $\mathrm{pH}$ at various time intervals, but the most important ones are after two and 60 minutes. 
TABLE V

SOIL NaF PH RESULTS

\begin{tabular}{|c|c|c|c|c|c|c|}
\hline $\begin{array}{c}\text { soil } \\
\text { sample }\end{array}$ & $\begin{array}{c}\mathrm{pH} \\
(1 \mathrm{~min}) \\
\end{array}$ & $\begin{array}{c}\mathrm{pH} \\
\text { (2min) }\end{array}$ & $\begin{array}{c}\mathrm{pH} \\
(3 \mathrm{~min})\end{array}$ & $\begin{array}{c}P H \\
(5 \mathrm{~min}) \\
\end{array}$ & $\begin{array}{c}\mathrm{pH} \\
(30 \mathrm{~min}) \\
\end{array}$ & $\begin{array}{c}\text { pH } \\
\text { (60min) }\end{array}$ \\
\hline $\mathrm{NaF}$ (blank) & 9.5 & 9.5 & 9.5 & 9.5 & 9.5 & 9.5 \\
\hline 1MH 1 & 9.9 & 9.9 & 9.9 & 10.0 & 10.5 & 10.6 \\
\hline 1MH2 & 9.8 & 9.9 & 10.0 & 10.0 & 10.3 & 10.6 \\
\hline 2MH 1 & 10.0 & 10.2 & 10.4 & 10.4 & 10.5 & 10.8 \\
\hline $2 \mathrm{MH} 2$ & 9.9 & 10.1 & 10.4 & 10.4 & 10.6 & 10.6 \\
\hline SAI & 9.8 & 10.0 & 10.2 & 10.2 & 10.2 & 10.4 \\
\hline SA2 & 9.4 & 9.9 & 10.0 & 10.1 & 10.2 & 10.4 \\
\hline $\mathrm{SA} 3$ & 9.2 & 9.7 & 9.9 & 10.0 & 10.1 & 10.4 \\
\hline $1 \mathrm{EC} 1$ & 9.7 & 10.0 & 10.0 & 10.1 & 10.0 & 10.1 \\
\hline $1 \mathrm{EC} 2$ & 10.4 & 10.5 & 10.6 & 10.6 & 10.9 & 10.9 \\
\hline $1 E C 3$ & 9.5 & 10.1 & 10.4 & 10.5 & $10.6^{\circ}$ & 10.8 \\
\hline $3 E C 1$ & 9.3 & 9.6 & 9.7 & 9.8 & 9.7 & 9.6 \\
\hline $3 E C 2$ & 10.3 & 10.4 & 10.4 & 10.5 & 10.4 & 10.5 \\
\hline $3 E C 3$ & 10.2 & 10.3 & 10.3 & 10.3 & 10.3 & 10.4 \\
\hline $3 E C 4$ & 10.6 & 10.7 & 10.8 & 10.8 & 10.9 & 11.1 \\
\hline $3 \mathrm{EC} 5$ & 10.5 & 10.5 & 10.6 & 10.6 & 10.8 & 11.0 \\
\hline $4 E C 1$ & 9.9 & 9.9 & 9.9 & 9.9 & 9.9 & 10.0 \\
\hline $4 E C 2$ & 10.5 & 10.6 & 10.6 & 10.8 & 10.9 & 11.1 \\
\hline $4 E C 3$ & 10.6 & 10.8 & 10.9 & 10.9 & 11.1 & 11.2 \\
\hline
\end{tabular}

Notes: Matterhorn (MH), Sacajawea (SA), Eagle Cap (EC). 
Sodium fluoride $\mathrm{pH}$ tests for the Eagle Cap soils exemplified the importance that volcanic ash lalmost certainly Mazama) has on the soil. Each of the samples 1EC, $3 E C$ and 4EC, all exceeded 9.4, the criteria for allophane content (Soil Survey Staff 1975: 47). The lowest level for Eagle Cap soil samples is 9.6 for the soil at the third site (3EC1) (Table 5).

Although Matterhorn and Sacajawea pH readings are not as high as Eagle Cap samples, they do exceed the necessary level (9.4) for significant ash content. The Matterhorn summit samples provide a uniform pH of 9.9, although the toe slope samples are higher reaching 10.2 (2MH1) and 10.1 (2MH2) (Table 4). Sacajawea's samples show a decrease in significance with depth. The samples here range from 10 at the surface (SA1), to 9.7 at the deepest sample (SA3).

The $1: 1 \mathrm{pH}$ test exhibited an acidity level higher than expected in the alpine environment. The lowest reading was 6.2 (on Eagle Cap) and the highest $\mathrm{pH}$ was from the Matterhorn at 7.3 (Table 5). Although the $\mathrm{pH}$ readings were fairly high, it was apparent that organic matter did have some influence on the soils. One discrepancy did arise, the $5.8 \mathrm{CaCl}_{2} \mathrm{pH}$ reading for the Matterhorn summit, which owing to the lack of vegetation, was difficult to explain.

The $\mathrm{pH}$ results display the influence parent material has. This was evident on the marble and shale geology where pH was higher than expected on the granodiorite. However, the 
$\mathrm{pH}$ was still high on the granodiorite due to the influence of the marble loess. From the pH tests it is ascertained that vegetation plays an important part in soil development, causing the $\mathrm{pH}$ to increase with depth as the organic content decreases in concentration.

The wide distribution of Mazama ash throughout the Wallowa Mountains is supported by the sodium fluoride (NaF) $\mathrm{pH}$ test. Visual inspection had shown ash presence at lower elevations and was confirmed by discussions with the U.S. Forest Service personnel (Tim Bliss, personal communication 1994). The NaF pH tests the amorphous $\mathrm{AI}$ in soils among other things, providing a reflection of ash content, by measuring the dominant presence of active $\mathrm{Al}-\mathrm{OH}$ groups in the soil (Theng 1980: 103). According to the USDA Soil Taxonomy (Soil Survey staff 1975: 47), in a 1 gram soil/ $50 \mathrm{ml}$. 1N NaF solution, if the $\mathrm{pH}$ reads greater than 9.4 after 2 minutes, there is a dominance of amorphous material. Sodium fluoride readings indicate that all soil samples tested exceeded the criteria for highly amorphous soils.

\section{Soil Organics}

The reaction of the dichromate ion in acid solution oxidizes the carbon present, and provides a percentage of organic carbon which can also be used to calculate the organic matter content. In tests the samples turned from green to blue to red and the organic content was calculated (Table 6). 
The soil samples from Eagle Cap show a slight increase in amounts of organic matter moving downslope (Table 6). The organic carbon decreases with depth in the summit site from $3.2 \%$ in the A horizon (1EC1) to $0.8 \%$ in the Cox horizon (1EC3) (Table 6). There is a higher organic carbon in soil sample 3EC1 (3.9\%), although this again decreases with depth in the soil profile to $1.31 \%$ (3EC5). One interesting feature was the higher carbon value of sample 3 EC3 than the overlying $3 E C 2$. This is most probably due to a higher ash content in the horizon.

Soils from the lowest Eagle Cap sample site ( $4 E C$ ) exhibit a similar decrease with depth of organic carbon from $3.81 \%(4 \mathrm{EC} 1), 2.76 \%(4 \mathrm{EC} 2)$, to $1.75 \%$ (4EC3) (Table 6). The soil profile does not indicate any apparent bioturbation or extensive translocation. Not surprisingly, soils examined on Matterhorn and Sacajawea barely contain any organic content (Table 6). The maximum is $1.2 \%$ organic carbon, from the sample taken from the toe slope of the Matterhorn catena (2MH1) (Table 6). However, this is only evident in the surface sample, as it decreases to $0.7 \%$ (2MH2) with depth. The summit soils contained $1.6 \%$ (1MH1) and $1.2 \%$ (1MH2) respectively.

Interestingly, the percentages do reflect the presence of organic matter and serve to support the earlier $2: 1 \mathrm{pH}$ 
TABLE VI

SOIL ORGANIC CONTENT

\begin{tabular}{cccc}
\hline Soil Sample & mmeSO4 & $\begin{array}{c}\text { \% Organic } \\
\text { Carbon }\end{array}$ & $\begin{array}{c}\text { Organic } \\
\text { Matter }\end{array}$ \\
\hline Blank & 9.1 & 0 & 0 \\
1MH1 & 7.0 & 0.9 & 1.6 \\
1MH2 & 7.5 & 0.7 & 1.2 \\
2MH1 & 6.4 & 1.2 & 2.1 \\
2MH2 & 8.1 & 0.4 & 0.7 \\
SA1 & 7.6 & 0.4 & 0.6 \\
SA2 & 7.6 & 0.7 & 1.1 \\
SA3 & 7.6 & 0.7 & 1.1 \\
IEC1 & 1.7 & 3.2 & 5.6 \\
IEC2 & 6.3 & 1.2 & 2.1 \\
IEC3 & 7.3 & 0.8 & 1.4 \\
3EC1 & 0.3 & 3.9 & 6.7 \\
3EC2 & 2.6 & 2.9 & 4.9 \\
3EC3 & 1.3 & 3.4 & 5.9 \\
3EC4 & 4.6 & 2.0 & 3.4 \\
3EC5 & 6.1 & 1.3 & 2.3 \\
4EC1 & 0.4 & 3.8 & 6.6 \\
4EC2 & 2.8 & 2.8 & 4.7 \\
4EC3 & 5.1 & 1.8 & 3.0 \\
\hline
\end{tabular}

Notes: Matterhorn (MH), Sacajawea (SA), Eagle Cap (EC).

a Empirically derived by multiplying o Organic Carbon by 1.72 .

${ }^{b}$ Sample titrated with standardized $\mathrm{FeSO}_{4}$ at 8.2 (not 9.1). 
tests. Apparently, there is organic influence in the Matterhorn summit soils, signifying the beginnings of development. Once again the organic content is fairly minimal on the sacajawea summit samples but is higher (1.1) with depth, supporting the notion that recent deposition of eolian sediments has occurred. Organic carbon testing proves that there is a decrease of organic content with depth on the Eagle Cap soils, however, vegetation is certainly influences pedogenesis. The soils on Matterhorn and Sacajawea have a slight organic content and with further eolian influx are beginning to develop into "soils".

\section{Silt Mineralogy}

Silt mineralogy, used to obtain mineral constituents in soil, is particularly useful in determining the exact content of the eolian silts. Due to time constraints, it was conducted on only two samples, taken from the lower horizons of the Eagle Cap (Bw) summit (1EC2) and Matterhorn (C2) summit (1MH2).

The mineral peaks on the Kutnohorite calcium (dirty carbonate) bedrock of the Matterhorn show fairly large quartz $\left(7.8^{\circ}\right)$ and feldspar $\left(12.5^{\circ}\right)$ peaks, found at $26.6^{\circ}$ and $27.7^{\circ}$ 20 respectively (Appendix D), indicating that there is noncarbonate parent material present (Reka Gabor, personal communication). The calcite 20 peak is the highest located at $28.5^{\circ}$. The presence of these minerals in decent sized quantities, and the composition of parent material supports 
the claim that there are allochtonous (eolian) materials being deposited in the alpine zone of the Wallowas. Quartz and feldspar are uncommon in weathered marble. This justifies the idea that soil development certainly relates to the quantity of eolian sediments deposited. It also supports the field and other laboratory evidence that soil is developing, if only slowly, on the summit of the Matterhorn.

Similarly, on the sample from Eagle Cap where the parent material is granodiorite (Appendix E), a calcite peak of just over 10 at $29.5^{\circ} 20$, indicates that there is some allochtonous matter deposited. The quartz and feldspar in this example are the noticeable higher peaks. Although earlier particle size analysis suggested allochtonous material (eolian fines) is minimal, it is probably because any eolian matter deposited is rapidly removed, either through translocation or bioturbation. Instead, the Eagle Cap sample (1EC2) justifies the importance of the "eolian zone" and eolian sediments in alpine soil development in the region.

The silt mineralogy testing, combined with the previous tests and results, suggests that an important component of the soils developing on the slopes of Eagle Cap and Matterhorn is provided by the influx of eolian sediments. While only two samples were tested, this eolian influence is probably true of most of the mountain range, and it may be predicted that other peaks will also exhibit substantial 
quantities of finer material (Table 1), although this would depend on the soil matrix and vegetation, as to how much was included in the soil profile.

\section{Classification}

Attempts to classify the soils were made using the soil Survey Staff (1992) and the FAO/UNESCO classification systems (Lof 1987). However, the soils were only classified on the Eagle Cap catena, since the other sites despite having residual material, had not developed enough to be called soils.

According to the Soil Map of Oregon (USDASCS 1986), the soils that characterize the Wallowa Mountains are Udic-Cryic soils, either on rock outcrops or rubble land, with the soil Great Group being Cryorthents. More development was found in the Eagle Cap alpine soils, in that they are Inceptisols, predominantly weathered rock under a cryic (cold) temperature regime, with little or no evidence of permafrost. The soils sampled in this study are classified in the field as Lithic Dystric Cryochrepts and Typic Cryumbrepts, although later laboratory tests demonstrated that samples contained a significant amount of allophane content. According to the FAO classification, alpine soils in the region probably fall into the Cambisol classification, being either Eutric or Dystric Cambisols. However, the influence of ash suggests classification change to the Andosol order. 
The change in soil classification using the U.S. Soil Survey method would be to consider the soils Andepts (volcanic Inceptisols). However, the $\mathrm{pH}$ ( 9.4 or more according to Soil Taxonomy) readings justifies classifying them as the newer soil order, Andisols. This would be fairly synonymous with the FAO classification for either Humic, Ochric or Vitric Andosols.

Further justification for the soils' andic component is provided by the U.S. Soil Survey Handbook (1992). For Andisols, it states that the soil must have andic properties in $60 \%$ or more of thickness within $60 \mathrm{~cm}$ of the soil surface (Soil Survey staff 1992: 24). This means that there is less than 25\% of organic carbon and dominance by amorphous minerals. The andic properties of the soil were confirmed by the sodium fluoride (NaF) $\mathrm{pH}$ tests and supported by silt mineralogy evidence for eolian material deposition. This leaves little choice, but to classify the soils on Eagle Cap as Iithic Haplocryands, except for site 3EC (Typic Haplocryands), maintaining the fact that the "soils" on the other peaks are simply too young to be classified, other than Andisols that are influenced by the local bedrock.

The evidence provided by the laboratory tests and subsequent classification designates a region that is partially devoid of alpine soils. Soil has developed on Eagle Cap and is fairly widely distributed. However, on the other sites, Matterhorn and Sacajawea, the only soil present is a 
covering of eolian deposits, translocated only due to the greater soil matrix provided by the weathered bedrock. 
CHAPTER VII

\section{DISCUSSION}

\section{Field and Laboratory Results}

Both field and laboratory results provide conclusive data as to the extent of development of the alpine soils in the Wallowas. According to particle size analysis, the soil samples are poorly sorted, coarse-grained (gravel and sands) with low amounts of fine sediments. $89 \%$ of the soils contain $>50 \%$ of particles sand-sized or larger, with the highest being $92.9 \%$ in the case of the Matterhorn toe slope sample $(2 \mathrm{MH} 2)$. Silt and clay content was minimal for all soil samples, although the upper sample from sacajawea (SA1) contained $14 \%$ silt, and $6 \%$ clay. The substantial quantity, in this sample as well as the others from that site, indicates that eolian sediments are a very important pedogenic factor at the site. Even so, the Sacajawea soil still maintains a fairly high quantity (over $75 \%$ ) of greater than sand-size particles, signifying the lack of soil development at the site.

Eagle Cap soils are also predominantly coarse soils, although field work, particle size analysis and silt mineralogy tests, showed that they also contain some finer sediments. The presence of finer material is again attributed 
to the eolian factor. However, the sediment is distributed throughout the profile by translocation, a process of soil development.

The importance of the organic content in the soils was first established by using Munsell colors, then by laboratory $\mathrm{pH}$ tests to determine the extent of organic influence. While the $1: 1$ water and $2: 1 \mathrm{CaCl}_{2} \mathrm{pH}$ tests were expected to be much lower than they actually were, it was apparent that organic matter had an influence on all the soils, as the $\mathrm{pH}$ increased with depth. One discrepancy did arise, the $5.8 \mathrm{CaCl}_{2} \mathrm{pH}$ reading for the Matterhorn summit. Owing to the apparent lack of vegetation at the site, it was difficult to explain this.

The $\mathrm{pH}$ tests signified that parent material influenced the soil. On granodiorite sites the $\mathrm{pH}$ was lower than the marble and shale sites, however, $\mathrm{pH}$ was still higher than expected due to marble loess influence. It was believed that the Mazama Ash present in the soil also raised the $\mathrm{pH}$. The $\mathrm{pH}$ test along with organic carbon, also exhibited the vegetation influence as the $\mathrm{pH}$ increasing with depth. This is because the organic content decreases in concentration, thereby allowing the $\mathrm{pH}$ to increase. All the sites exhibited a high amount of organic carbon present.

Sodium fluoride $\mathrm{pH}$ readings supported the claim that Mazama Ash distribution is widespread in the Wallowas. Although visual inspection had already shown ash presence at lower elevations, sodium fluoride readings proved that the 
soils tested exceeded the criteria for highly amorphous soils. Therefore the alpine soils had a high ash component. The highest reading is 10.8 from the $4 E C 3$ sample, which indicates high levels of translocated allophane. High readings (above 10 ) are also evident for the other Eagle Cap sites, which also display a reasonable amount of translocation.

Amorphous aluminum is also present on the Matterhorn and Sacajawea. The Matterhorn summit soil could now be considered a uniform $C$ horizon (both samples $9.9 \mathrm{NaF} \mathrm{pH}$ ), that contained high quantities of allophane. Sodium fluoride $\mathrm{pH}$ readings exhibit a greater influence at the toe slope than at the summit (10.2 and 10.1). Sacajawea summit soils decrease in ash influence with depth, from 10 to 9.7 . The soil is still characterized as having a uniform $C$ horizon, as the change in soil features is minimal.

Silt mineralogy peaks on the Matterhorn and Eagle Cap indicate that there is eolian parent material present, despite earlier particle size analysis suggesting it is minimal. It justifies the importance of the "eolian zone" and eolian sediments in alpine soil development in the region, as well as Mazama ash and vegetation influence. This confirms the hypothesis that eolian sediments are very important in soil development in the wallowas. Two other interrelated theories need to be mentioned however, that pertain more to soil distribution, and provide further evidence for the 
differences on Eagle Cap compared to the Matterhorn and Sacajawea.

\section{Nunatak Hypothesis}

The Nunatak Hypothesis (Ives 1966 ) relates to the development and distribution of soil in the Wallowas, because much of the previous research in the area, concluded that the higher mountain peaks in the Wallowa landscape are nunataks, rock masses that protruded above the alpine ice sheet. An intriguing notion here is how the warmth of the mountain mass might lessen the ice cover, thereby creating a nunatak (Ives 1966). Obviously, this would improve the chance of vegetation survival, and in turn, greatly affect the soil development. The soil should continue to develop during the Ice Age, however this does not explain the shallow depth of soil found on the summit of Eagle Cap.

While the exposure of the higher peaks would allow soil to develop, and chemical weathering would be possible, the soils along the Eagle Cap catena indicate a vastly different profile compared to the soils on Sacajawea and Matterhorn. Despite their exposure during the Ice Age, the latter two sites show little or no development other than the influence of eolian silts. The explanation for this is probably the fact that they are steeper, windier sites, and therefore are less conducive to soil development. However, another idea might have bearing on their lack of development. 
The idea that mountain mass or size has an effect on climate and acts as a heat island thereby increasing temperatures and subsequently affecting the extent of treeline is called the Massenberung Factor (Price 1981; Arno 1984; Swanson et al. 1988). Mountain mass is visible in other alpine areas, such as the Cascades, and with a greater mass, vegetation will increase, albeit mainly on the warmer slopes. Similarly, vegetation would decrease where the topography is mainly steep, narrow ridges.

Although the idea is accepted as a reason for vegetation increase and/or species migration, it apparently has an effect on the soil. The increased plant cover serves as an improved wind trap for eolian sediments. Furthermore the warmer mountain would be less susceptible to ice cover, providing a refugia for plant species and allowing continued soil development. While the alpine soil is slightly better developed on Eagle Cap, if it was a nunatak then the soil should be more developed. The effect of the mountain mass on Eagle Cap, Matterhorn, and Sacajawea cannot be determined from the soil development, and it is difficult to conclude what effect it has had in the Wallowas (Figure 32).

The development of soil in the Wallowas is primarily a factor of parent material (including eolian sediments), vegetation, and topography. The importance of wind-blown materials is reflected by the apparent presence of Mazama Ash. While the factors of soil formation naturally play a 


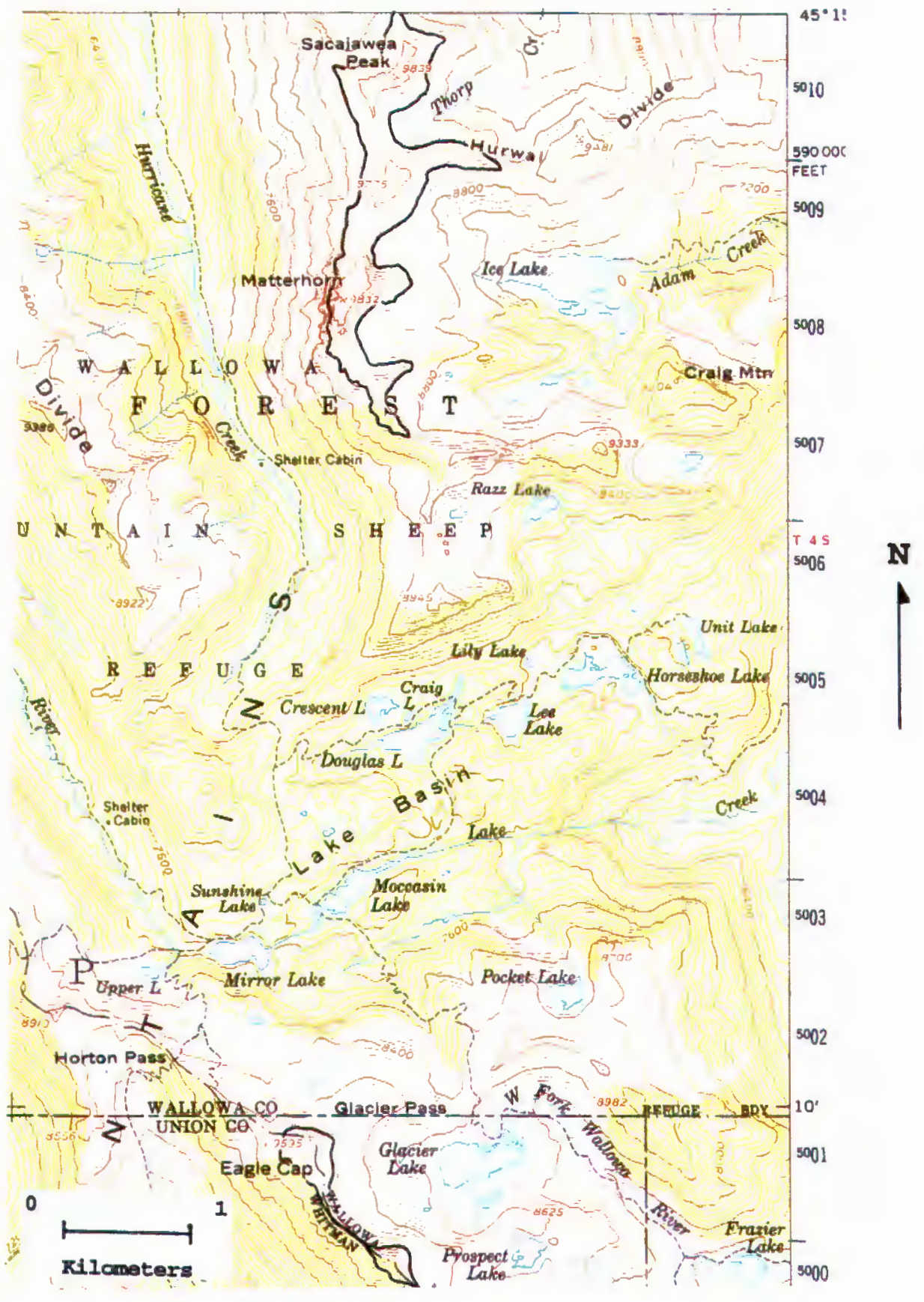

Eigure 32. Mountain Mass. $\approx$ drawn around the 9,200 feet contour line to display contrasting mountain sizes. 
part, it is the presence of the eolian fines, different parent material, and the geomorphic history that play the main role in development of the soils. This explains the differences observed between the various peaks, and why Eagle Cap soils demonstrate improved development over the soils on the other two peaks, Matterhorn and Sacajawea. 
CHAPTER VIII

CONCLUSIONS

Alpine soils in the Wallowa Mountains are similar to soils in other mountain environments. They range from moderately-developed soils (Inceptisols and Andisols) to no soil cover at all. The soils are mainly loamy sand in texture, lack structure, and have a pH range of 6.5 to 7.3 (1:1 water). They are mainly 10YR and $2.5 \mathrm{Y}$ in color.

The amount of soil development on the summit and slopes of Eagle cap results from the high eolian sediment influx from the surrounding plateau, timberline and topography. Proof for eolian presence is provided by quartz and feldspars in the marble soils, and by calcite in the granodiorite soils. This is unlike the Matterhorn and sacajawea soils, where despite the larger matrix provided by the granular texture,. making it easy for eolian translocation, soil development is poor. Despite the importance of the eolian component in soil development, it does not dominate the Wallowa system, neither does it leave the fine A horizon found in other alpine areas. However, other than this silt accumulation the soils are still poorly developed. This may relate to the type of parent material, which ranges from granodiorite to marble. Granodiorite sites exhibit the best 
developed soils. This is because basalt weathers into blocks and does not provide an adequate soil matrix for eolian translocation like the granodiorite, while the marble and shale sites consist mainly of detritus. The narrow summit, steep gradient and ridges of the latter two sites also hinder soil development except in small areas.

Treeline extent on Eagle Cap is nearer the summit (Figure 33) which also improves the chance for soil to develop. However, despite the increased amount of vegetation, notably in the form of krummholz, the characteristics of the soils are similar to the soil underlying the alpine turf, with the exception of a thinner A horizon. This occurs because the whitebark pine krummholz site is windblown, there is less snowcover, and subsequently little or no leaching which creates a weak soil lacking in moisture. One feature is evident for all soils on Eagle Cap, the presence of organocutans, which are formed from translocated organics that are deposited on the bottom of rocks in the $B$ horizon (Burns, 1980). However, their presence is not enough to affect the soil $\mathrm{pH}$. Instead, the $\mathrm{pH}$ reflects a decrease in organic carbon and organic matter with depth and means that bioturbation is either minimal, or the soils recover rapidly. The $\mathrm{pH}$ increase with depth shows the surficial influence of organics, the translocation of marble loess (on Eagle Cap) with depth, and also the presence of ash. 


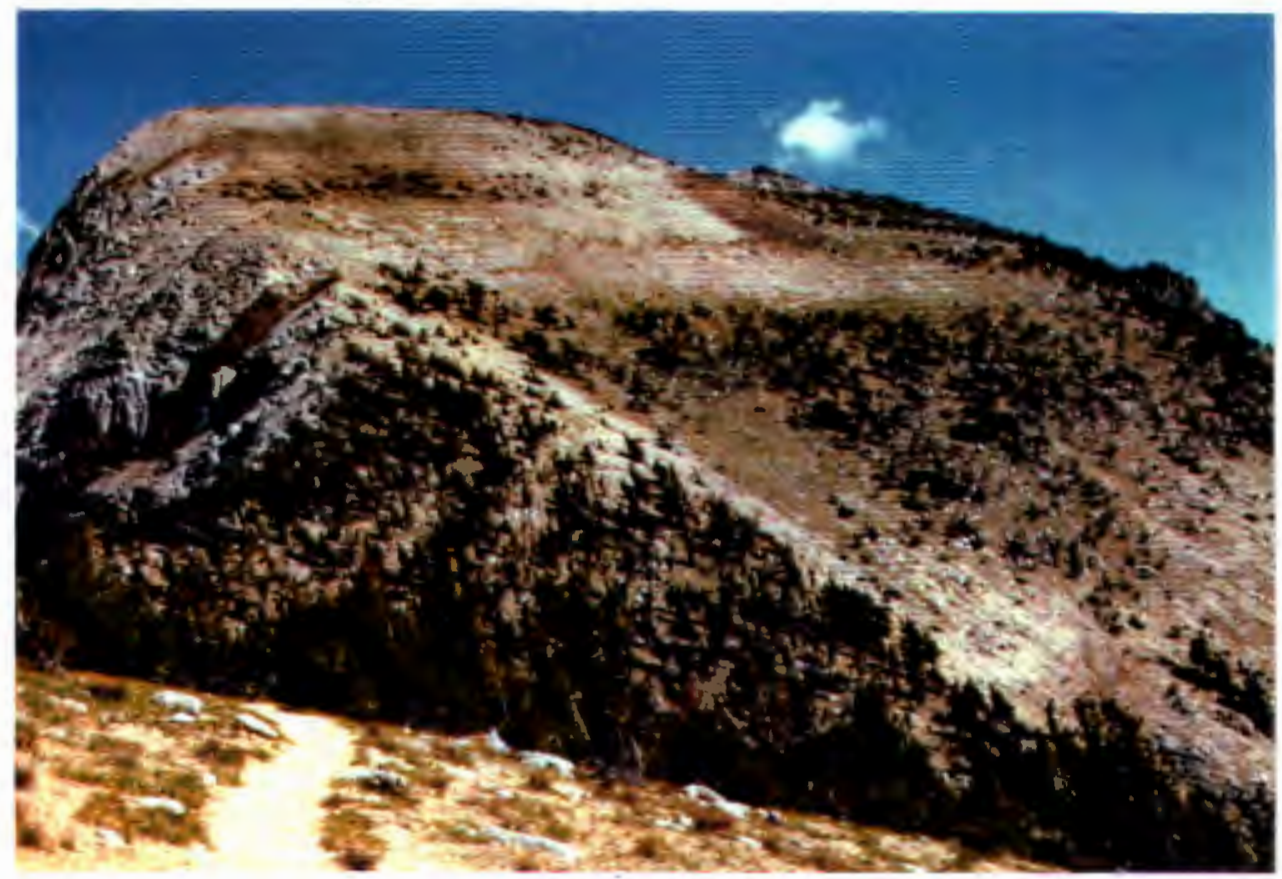

Eigure 33. Extent of Treeline on Eagle Cap's northwest slope. Photograph taken from Horton Pass. Note Basalt dike. 
The amount of vegetation on Eagle cap may also relate to the nunatak idea and increased mountain mass effect, which modifies the environment and in turn makes it more favorable for soil development. Even so, it is questionable as to how much effect the nunataks have had on soil development, and whether it can be determined from the results in this study. Considering the soils should be over 20,000 years old (if they protruded above the ice) they are not as well-developed as was postulated. Similarly, the effects of mountain mass may not be determined by the soil characteristics.

The effects are certainly not visible on the Matterhorn and Sacajawea, where soil development has been minimal. These two peaks occur in too young an environment for them to exhibit soil development.

The conclusion is that alpine soils in the Wallowa Mountains are relatively poorly-developed. Soils that are found on Matterhorn and Sacajawea are simply accumulations of eolian materials and weathered parent material and have yet to develop as soil. Eagle Cap exhibits the best catena profile, much like that of the Synthetic Alpine slope (SAS) proposed by Burns and Tonkin (1982). However, soil development along the catena is still minimal (maximum depth observed $85 \mathrm{~cm}$ ), and soil horizons are less developed than those described in the model from Colorado. This reflects the smaller alpine zone of the Wallowas with only Minimum Snowcover (MSC) and Windblown (WB) sites present, which 
decreases the sample size. Despite the various stages of development, the soils do provide an account of the interrelating features in the alpine environment and reflect many of the criteria that are used in formulating the Synthetic Alpine Slope model.

The Eagle Cap soils are developed enough to allow classification and may be considered Inceptisols, Lithic Dystric Cryochrepts, and Typic Cryumbrepts, (WB and MSC sites, Figure 8) under the USDA system. According to the FAO system they would be classified as Eutric or Dystric Cambisols. However, laboratory results indicate that the Eagle Cap soils should be classified as Andisols according to the new USDA soil order. The predominant soils are Lithic Haplocryands, with Typic Haplocryands occurring on the deeper soils (3EC). This classification is supported by the extensive covering of ash in the Wallowas and the profound influence it has on the soils.

Therefore, the biggest influences on alpine soil distribution in the Wallowa mountains are eolian sediments (inclusive of Mazama Ash), parent material, topography, and organics. Distribution of the alpine soil in the Wallowa Mountains favors the influx of loess, as proven by the silt mineralogy tests, field examination, and sodium fluoride (NaF) pH testing. The importance of eolian sediments has been evaluated before in the Colorado Front Range and determined by mineral analysis to be highly influential (Litaor 1987). 
Eolian sediments are especially important in the form of Mazama Ash which is widely distributed across the Pacific Northwest (Bockheim et al. 1969). An interesting supporting argument was provided by Price (1985) who noted the importance of an "eolian zone," mentioning the wide extent of grasshoppers at elevations exceeding 2,450m. The expected source area for these was from the agricultural areas to the South, the Grande Ronde and Baker Valley (Price 1985: 218). This could be equally applied to eolian sediments.

Parent material exerts its influence in either increasing the amount of development (granodiorite and basalt) or affecting the eolian sediment influx and subsequent translocation in the soil matrix (marble, shale, and ash).

The importance of topography relates mainly to control of the extent of vegetation, as well as how steep the slopes are in preventing soil development. Whereas steep slopes are an obvious limiting factor, vegetation's importance is visible through apparent lack of change (minimal) on the Eagle Cap slopes and the moderate levels of organic matter throughout the soil profile. When the extent of vegetation on Eagle Cap is related to topography and the aforementioned theories of mountain mass effect, nunataks, and treeline, it is apparent that vegetation is associated with the extent of soil development. This is not as evident on the narrow 
summits of the Matterhorn or Sacajawea, where soil distribution is minimal or non-existent.

\section{FUTURE WORK}

Further soil studies need to be conducted in the Wallowas on other peaks that exceed 2,900 meters, such as Aneroid Mountain, Chief Joseph Mountain and Pete's Point, in an endeavor to provide a thorough alpine soil classification of the available soils in the area. This would further the understanding of the effects of recreation in the region. Whereas the improvement of soils with prevention of grazing is visible, further studies at higher elevations are clearly necessary, while there has yet to be a comprehensive study that has ascertained the infliction increased human recreational use is having on the area. This might prove especially important on areas where soil has yet to develop.

Although a soil survey is available for Union county (Dyksterhuis and High 1985), it omits the wilderness area. Similarly there are yet to be soil surveys for Baker or Wallowa county (nearing completion) that would deal with the Wallowa Mountains. These are necessary as the region continues to develop, both as a recreational area and agricultural region.

The alpine soils in the Wallowas also need to be further examined for andic properties, which might redefine classification. Andisols are a relatively new soil order, and 
very few studies have dealt with them in an older alpine setting. In doing so, this is necessary not only for the Wallowas, but other areas throughout the Pacific Northwest.

Finally, work needs to be conducted on the clay mineralogy of the soils in the Wallowas. This would provide information as to how well-developed the alpine soils are and might answer the nunatak questions. 


\section{REFERENCES CITED}

Allen, J. E. 1975. The Wallowa "Ice Cap" of Northeastern Oregon. The Ore Bin 37(12):189-202.

Allison, I. E. 1965. Organic Carbon. In Methods of Soil Analysis pt.II., ed. C. A. Black, pp.1367-1378. Madison, Wisconsin: American Society of Agronomy.

Amundson, R., Harden, J., and Singer, M., eds. 1994. Factors of Soil Formation: A Fiftieth Anniversary Retrospective. Madison: Soil Science Society of America.

Archer, A. C. and Cutler, E. J. B. 1983. Pedogenesis and Vegetation Trends in the Alpine and Upper Subalpine zones of the Northeastern Ben Oahu Range, New Zealand. New Zealand Journal of Science 26:127-150.

Arno, S. F. 1984. Timberline: Mountain and Arctic Forest Frontiers. Seattle: The Mountaineers.

Bamberg, S. A. and Major, J. 1968. Ecology of the Vegetation and Soils Associated with Calcareous Parent Materials in Three Alpine Regions of Montana. Ecological Monographs $38(2): 127-167$.

Barry, R. G. 1973. A Climatological Transect Along the East Slope of the Front Range, Colorado. Arctic \& Alpine Research $5: 89-110$.

Barsch, D. and Caine, N. 1984. The Nature of Mountain Geomorphology. Mountain Research and Development $4(4): 287-298$.

Bentley, E. B. 1974. The Glacial Morphology of Eastern Oregon Uplands. Ph.D. Dissertation, Department of Geography, University of Oregon.

Berry, M. E. 1987. Morphological and Chemical Characteristics of Soil Catenas on Pinedale and Bull Lake Moraine Slopes in the Salmon River Mountains, Idaho. Quaternary Research $28: 210-225$.

- 1994. Soil-Geomorphic Analysis of Late Pleistocene Glacial Sequences in the McGee, Pine and Bishop Creek Drainages, East-central Sierra Nevada, California. Quaternary Research 41(2):160-175. 
Billings, W. D., and Mooney, H. A. 1968. The Ecology of Arctic and Alpine Plants. Biological Reviews of the Cambridge Philosophical Society 43:481-529.

Birkeland, P. 1984. Soils and Geomorphology. New York: Oxford University Press.

- 1990. Soil-Geomorphic Research: A Selective Overview. In Soils and Landscape Evolution: Proceedings of the 21st Annual Binghampton Geomorphology Symposium, ed. P. L. K. Kneupfer and L. D. McFadden, pp. 207-224. Amsterdam: Elsevier.

- 1994. Variation in Soil-Catena Characteristics of Moraines with Time and Climate, South Island, New Zealand. Quaternary Research 42:49-59.

Birkeland, P. W. and Burke, R. M. 1988. Soil Catena Chronosequences on eastern Sierra Nevada Moraines, California, USA. Arctic \& Alpine Research 20:473-484.

Birkeland, P. W., Burke, R. M. and Shroba, R. R. 1987. Holocene Alpine Soils in Gneissic Cirque Deposits, Colorado Front Range-Soil Chronosequences in the Western United States. United States Geological Survey Bulletin 1590-E. Washington D.C.: U.S. Government Printing Office.

Birkeland, P. W. and Janda, R. J. 1971. Clay Mineralogy of Soils Developed from Quaternary Deposits of the Eastern Sierra Nevada. GSA Bulletin 82:2495-2514.

Birkeland, P. W., Machette, M. N. and Haller, K. M. 1991. Soils as a tool for Applied Quaternary Geology. Utah Geological Survey Miscellaneous Publication 91-3.

Black, C. A. 1965. Methods of Soil Analysis. Madison: American Agronomy Society.

Bliss, T. 1994: Hydrologist, U.S. Forest Service, Enterprise, personal communication.

Bockheim, J. G. 1978. A Comparison of the Morphology and Genesis of Arctic Brown and Alpine Brown Soils in North America. In Quaternary Soils, ed. W. C. Mahaney, pp. 427-452. Norwich, U.K.: Geoabstracts.

- 1980. Solution and use of Chronofunctions in Studying Soil Development. Geoderma 24:71-85. 
Bockheim, J. G. and Burns, S. F. 1991. Pergelic Soils of the Western Contiguous United States: Distribution and Taxonomy. Arctic \& Alpine Research 23(2):206-212.

Bockheim, J. G., Schlicte, A. K., Crecelius, E. A., Kummer, J. T., Pongsapich, W., Tenbrink, N. W., Weber, W. M. and Gresens, R. L. 1969. Compositional Variations of the Mazama ash as Related to Variation in the Weathering Environment. Northwest Science, 43(4): 162-173.

Bouyoucos, G. J. 1936. Directions for Making Mechanical Analysis of Soils by the Hydrometer Method. Soil Science $41: 225-229$.

Burns, S. F. 1980. Alpine Soil Distribution and Development, Indian Peaks, Colorado Front Range. Ph.D. Dissertation, Department of Geology, University of Colorado, Boulder.

- 1985. Classification and Development of Alpine Soils, Southern Rocky Mountains, USA. In Proceedings of International Meeting on Classification and Management of Soils of Mountain Regions, pp.72-85. Sofia, Bulgaria: Bulgarian Soil Science Society.

-. 1990. Alpine Spodosols: Cryaquods, Cryohumods, Cryorthods, and Placaquods Above Treeline. In Proceedings of the 5th International Soil Correlation Meeting (ISCOM) on Characterization and Utilization of Spodosols, ed. J. M. Kimble and R. D. Yeck, pp.46-62. Bangor, Maine: ISCOM.

Burns, S. F. and Tonkin, P. J. 1982. Soil Geomorphic Models and the Spatial Distribution and Development of Alpine Soils. In Space and Time in Geomorphology, ed. C. E. Thorn, pp.25-43. Boston: George Allen \& Unwin Ltd.

Butler, B. E. 1959. Periodic Phenomena in Landscapes as a Basis for Soil Studies. CSIRO Australian Soil Publication 14 .

Caine, N. 1979. Rock Weathering Rates at the Soil Surface in an Alpine Environment. Catena 6:131-141.

Carson, R. J., Pohs, K. G. and Bixby, R. K. 1995. Geomorphology of Ice Lake Area, Wallowa Mountains. Proceedings of the Oregon Academy of Science 31:35

Chao, C.Y. 1969. Two o (Cu) Table for Common Minerals. Canada: Carleton University, Department of Geology Paper 69-2. 
Chesworth, W. 1973. The Parent Rock Effect in the Genesis of Soil. Geoderma 10:215-225.

Cole, D. N. 1981. Vegetational Change Associated with Recreational use and fire Suppression in the Eagle Cap Wilderness, Oregon: Some Management Implications. Biological Conservation $20(4): 247-270$.

- 1982. Vegetation of Two Drainages in Eagle Cap Wilderness, Wallowa Mountains, Oregon. USDA Forest Research Paper INT-288. Ogden, Utah: Intermountain Forest and Range Experiment Station.

Crandell, Dwight R., 1965, The Glacial History of Western Washington and Oregon. In Quaternary of the United States, ed. H. E. Wright Jr and D. G. Frey, pp. 341-354. Princeton, New Jersey: Princeton University Press.

- 1967. Glaciation at Wallowa Lake, Oregon. USGS Professional Paper 575-C, pp. 145-153. Washington D.C.: Government Printing office.

Dahlgren, R. A. and Marrett, D. J. 1991. Organic Carbon Sorption in Arctic and Subalpine Spodosol B Horizons. Soil Science Society of America Journal 55(5):1382-1390.

Dahms, D. E. 1994. Mid-Holocene Erosion of Soil Catenas on Moraines near the Type Pinedale Till, Wind River Range, Wyoming. Quaternary Research $42(1): 41-48$.

Davis, W. M. 1899. The Geographical Cycle. Geographical Journal $14: 481-504$.

Dixon, J. C. 1986. Solute Movement on Hillslopes in the Alpine Environment of the Colorado Front Range. In Hillslope Processes, ed. A. D. Abrahams, pp.139-159. London: Allen \& Unwin.

Dixon, J. C., Thorn, C. E. and Darmody, R. G. 1984. Chemical Weathering Processes on the Vantage Peak Nunatak, Juneau Icefield, Southern Alaska. Physical Geography 5(2):111-131.

Douglas, G. W. and Bliss, L. C. 1977. Alpine and High Subalpine Plant Communities of the Northern Cascade Range, Washington and British Columbia. Ecological Monographs $47(2): 113-150$.

Dyksterhuis, E. L. and High, C. T. 1985. Soil Survey of Union County Area, Oregon. U.S.D.A. Soil Conservation Service. In Cooperation with the Oregon Agricultural Experiment Station. 
Fieldes, M. and Perrott, K. W. 1966. The Nature of Allophane in Soils: Part Three-Rapid Field and Laboratory Test for Allophane. New Zealand Journal of Science 9:623-629.

Flint, R. F. 1971. Glacial and Quaternary Geology. New York: John Wiley \& Sons.

Follo, M. F. 1994. Sedimentology and Stratigraphy of the Martin Bridge Limestone and Hurwal Formation (Upper Triassic to Lower Jurassic) from the Wallowa Terrane, oregon. In Geology of the Blue Mountains Region of Oregon, Idaho, and Washington: Stratigraphy, Physiography, and Mineral Resources of the Blue Mountains Region, ed. T. L. Vallier and H. C. Brooks, pp. 1-27. United States Geological Survey Professional Paper 1439. Washington D.C.: U.S. Government Printing Office.

Franklin, J. F. and Dyrness, C. T. 1988. Natural Vegetation of Oregon and Washington. Corvallis, Oregon: Oregon State University Press.

Gabor, R. 1995. Research Assistant, Portland State University Department of Geology, personal communication.

Geist, J. M. and Strickler, G. S. 1970. Chemical Characteristics of Some Forest and Grassland Soils of Northeastern Oregon. I. Results from Reference Profile Sampling on the Starkey Experimental Forest and Range. U.S. Department of Agriculture Forest Service Research Note PNW-137. Portland, Oregon:

Gensac, P. 1990. Plant and Soil Groups in the Alpine Grasslands of the Vanoise Massif, French Alps. Arctic \& Alpine Research 22(2):195-201.

Gerrard, A. J. 1990. Mountain Environments: An Examination of the Physical Geography of Mountains. Cambridge, Massachusetts: The MIT Press.

- 1992. Soil Geomorphology. London: Chapman and Hall.

Goudie, A., Atkinson, B. W., Gregory, K. J., Simmons, I. G., Stoddart, D. R. and Sugden, D., eds. 1994. The Encyclopedic Dictionary of Physical Geography. 2nd ed. Oxford: Blackwell Publishing.

Hall, R. D. and Shroba, R. R. 1993. Soils Developed in the Glacial Deposits of the Type Areas of the Pinedale and Bull Lake Glaciations, Wind River Range, Wyoming, USA. Arctic \& Alpine Research 25(4):368-373. 
. 1995. Soil Evidence for a Glaciation Intermediate Between the Bull Lake and Pinedale Glaciation at Fremont Lake, Wind River Range, Wyoming, U.S.A. Arctic and Alpine Research 27(1):89-98.

Harden, J. W. and Taylor, E. M. 1984. A Quantitative Comparison of Soil Development in Four Climatic Regimes. Quaternary Research 10: 342-359.

Hilgard, E. W. 1911. Soils. New York: The MacMillan Company.

Howell, J. D. and Harris, S. A. 1978. Soil-Forming Factors in the Rocky Mountains of Southwestern Alberta, Canada. Arctic \& Alpine Research 10(2):313-324.

Ives, J. D. 1966. Block Fields, Associated Weathering forms on Mountain tops and the Nunatak Hypothesis. Geographiska Annaler 48a:220-223.

Ives, J. D. and Barry, R. G. 1974. Arctic and Alpine Environments. London: Methuen \& Co. Ltd.

Jenny, H. 1941. Factors of Soil Formation. New York: McGraw Hill.

- 1961. Derivation of State Factor Equations of Soil and Ecosystems. Soil Science Society of America Proceedings $25(5): 385-388$.

- 1980. The Soil Resource-Origin and Behaviour. New York: Springer-Verlag.

Johnson, D. L. and Watson-Stegner, D. 1987. Evolution Model of Pedogenesis. Soil Science 143(5):349-366.

Johnson, D. M. and Dart, J. D. 1982. Variability of Precipitation in the Pacific Northwest: Spatial and Temporal Characteristics. Water Resources Research Institute WRRI-77. Corvallis: Oregon State University.

Kiilsgaard, T. H. and Tuchek, E. T. 1984. Eagle Cap Wilderness and Adjacent Areas, Oregon. In Wilderness Mineral Potential: Assesment of Mineral-Resource Potential in USFS Lands Studied 1964-1984, ed. S. P. Marsh, S. J. Kropschot, and R. G. Dickinson, pp.869-871. U.S. Geological Survey Professional Paper 1300(2). Washington D.C.: US Government Printing Office. 
Kiver, E. P. 1974. Holocene Glaciation in the Wallowa Mountains, Oregon. In Quaternary Environments: Proceedings of Symposium, W. C. Mahaney ed. pp.169195. Geographical Monograph 5, North York, Ontario: York University.

Knuepfer, P. L. K. and McFadden, L. D., eds. 1990. Soils and Landscape Evolution: Proceedings of the 21st Binghampton Geomorphology Symposium. Amsterdam: Elsevier.

Legros, J. P. 1992. Soils of Alpine Mountains. In Weathering, Soils and Paleosols, I. P. Martini and W. Chesworth ed. pp.155-181. Amsterdam: Elsevier.

Lewis, D. W. 1984. Practical Sedimentology. New York: Von Nostrand Reinhold Company Inc.

Lindgren, W. 1901. The Gold Belt of the Blue Mountains of Oregon. U.S.Geological Survey 22nd Annual Report pt.2. pp.551-776. Washington D.C.: US Government Printing Office.

Litaor, M. I., 1987, The Influence of Eolian Dust on the Genesis of Alpine Soils in the Front Range, Colorado. Soil Science Society of America Journal 51:142-147.

Lof, P. ed. 1987. FAO Unesco: Soils of the World Wall Chart. Amsterdam: Elsevier.

Love, D. 1970. Subarctic and Subalpine: Where and What? Arctic and Alpine Research 2(1):63-73.

MacCormick, R. 1984. The Influence of Wind in Soil Pedogenesis in the High Wallowa Mountains. Proceedings of the Oregon Academy of Science 20:32.

Mahaney, W. C. 1974. Soil Stratigraphy and Genesis of Neoglacial Deposits in the Arapaho and Henderson Cirques, Central Colorado Front Range. In Quaternary Environments: Proceedings of a Symposium, W. C. Mahaney ed. pp. 197-240. North York, Ontario: Geographical Monograph 5, York University.

Mahaney, W. C. and Sanmugadas, K. 1983. Early-Holocene Soil Catena in Titcomb Basin, Wind River Mountains, Western Wyoming. Zeitschrift fur Geomorphologie 27(3):265-281.

Mahaney, W. C. and Spence J. 1984. Glacial and Periglacial Sequence and Floristics in Jaw Cirque, Central Teton Range, Western Wyoming. American Journal of Science $284(9): 1056-1081$. 
Mason, G. 1975. Guide to the Plants of the Wallowa Mountains of Northeastern Oregon. Eugene, Oregon: Special Publication of the Museum of Natural History, University of Oregon.

McKee, B. 1972. Cascadia: The Geologic Evolution of the Pacific Northwest. New York: McGraw Hill Book Company.

Milne, G. 1935. Some Suggested Units of Classification and Mapping, Particularly for East African Soils. Soil Research 4(3):183-198.

Munsell Color Company, Inc. 1954. Munsell Soil Color Chart. Baltimore: Munsell Color Company, Inc.

Neal, K. G. 1973. A Tectonic Study of a Part of the Northern Eagle Cap Wilderness Area, Northeastern Oregon. M.S. Thesis, Department of Geology, Portland state University, Portland, Oregon.

Nolf, B. O. 1966. Structure and Stratigraphy of Part of the Northern Wallowa Mountains, Oregon. Ph.D. Dissertation, Department of Geology, Princeton University, New Jersey.

O'Connor, K. F. 1984. Stability and Instability of Ecosystems in New Zealand Mountains. Mountain Research and Development $4(1): 15-29$.

Ollier, C. D. 1976. Catenas in Different Climates. In Geomorphology and Climate, ed. E. Derbyshire, pp.139169. New York: Wiley.

Orr, E. L., Orr, W. N. and Baldwin, E. M. 1992. Geology of Oregon. 4th ed. Dubuque, Iowa: Kendall/Hunt Publishing Company.

Ottersburg, B. 1995: Soil Scientist, LaGrande, personal communication.

Parsons, R. B. 1978. Soil-Geomorphology Relations in the Mountains of Oregon, USA. Geoderma 21:25-39.

Phillips, J. D. 1993. Stability Implications of the State Factor Model of Soils as a Nonlinear Dynamical System. Geoderma $58(1-2): 1-15$.

Pickford, G. D. and Reid, E. H. 1942. Basis for Judging Subalpine Grassland Ranges of Oregon and Washington. USDA Circular 655. 
Pope, G. A., Dorn, R. I. and Dixon, J. C. 1995. A New Conceptual Model for Understanding Geographical

Variations in Weathering. Annals of the Association of American Geographers 85(1):38-64.

Price, L. W. 1978. Mountains of the Pacific Northwest, USA: A Study in Contrasts. Arctic and Alpine Research $10(2): 465-478$.

- 1981. Mountains and Man. Berkeley: University of California Press.

- 1985. Grasshoppers on Snow in the Wallowa Mountains, Oregon. Northwest Science 59(3):213-220.

- 1994. Ecological Inversion in Wallowa Mountains, Oregon. Mazama 76(13):24-25.

Reheis, M. C. 1990. Influence of Climatic and Eolian Dust on the Major-Element Chemistry and Clay Mineralogy of Soils in the Northern Big Horn Basin, USA. Catena 17:219-248.

Retzer; J. L. 1950. Genesis and Morphology of Soils of Alpine Areas of the Rocky Mountains. Ph.D. Dissertation, Department of Soils, University of Wisconsin, Wisconsin.

- 1965. Present Soil-Forming Factors and Processes in Arctic and Alpine Regions. Soil Science $99(1): 38-44$.

- 1974. Alpine Soils. In Arctic and Alpine Environments, J. D. Ives and R. G. Barry ed. pp.771-802. London: Methuen \& Co. Ltd.

Richards, K. S., Arnett, R. S. and Ellis, S. 1985. Geomorphology and Soils. London: George Allen and Unwin.

Righi, D. and Lorphelin, L. 1986. Weathering of Silt and Clay in Soils of a Toposequence in the Himalayas, Nepal. Geoderma 39:141-155.

Ritter, D. F., Kochel, R. C. and Miller, J. R. 1995. Process Geomorphology. 3rd ed. Dubuque, Iowa: W. M. C. Brown Publishing.

Ross, C. P. 1938. Geology of Part of the Wallowa Mountains. Department of Geology and Mineral Industries Bulletin 3, Portiand, Oregon.

Sampson, A. W. 1909. Natural Revegetation of Depleted Mountain Grazing Lands. USDAFS Circular 169, Washington D.C.: Government Printing Office. 
Shroba, R. R. and Birkeland, P. W. 1983. Trends in the LateQuaternary Soil Development in the Rocky Mountains and Sierra Nevada of the Western United States. In Late Pleistocene. Volume 1: Quaternary Environment of the United States, ed. H. E. Wright Jr. pp.145-156. Minneapolis: University of Minnesota Press.

Smith, W. D. P. 1918. The Wallowa Mountains Geology and Economic Geography. Mazama 5(3):233-250.

Smith, W. D. P., Allen, J. E., Staples, L. W. and Lowell, W. R. 1941. Geology and Physiography of the Northern Wallowa Mountains, Oregon. In Oregon Department of Geology and Mineral Industries Bulletin 12.

Soil Survey Staff. 1975. Soil Taxonomy-A Basic System of Soil Classification for Making and Interpreting Soil Surveys. USDASCS Ag. Handbook 436.

- 1992. Keys to Soil Taxonomy. SMSS Technical Monograph 19, 5th ed. Blacksburg, Virginia: Pocahontas Press Inc.

Stovall, J. C. 1929. Pleistocene Geology and Physiography of the Wallowa Mountains (Oregon), with Special Reference to the Wallowa and Hurricane Canyons. M.S. Thesis, Department of Geology, University of Oregon.

Strickler, G. S. 1961. Vegetation and Soil Condition Changes on a Subalpine Grassland in Eastern Oregon. In USDA Forest Service Research Paper 40. Pacific Northwest Forest and Range and Experiment Station, Portland, OR.

Swanson, F. J., Kratz, T. K., Caine, N. and Woodmassee, R. G. 1988. Landform Effects on Ecosystem Patterns and Processes. Bioscience 38(2):92-98.

Tardy, Y., Bocquier, G., Paquet, H. and Millot, G. 1973. Formation of Clay from Granite and its Distribution in Relation to Climate and Topography. Geoderma 10:271-284.

Taubeneck, W. H. 1987. The Wallowa Mountains, Northeast Oregon. Geological Society of America Centennial Field Guide-Cordilleran Section. Volume 1. ed. M. L. Hill. pp.327-332. Boulder, Colorado: GSA Inc.

Theng, B. K. G., ed. 1980. Soils With Variable Charge. New Zealand Society of Soil Science. Palmerston North, New Zealand: offset Publications.

Thorn, C. E. 1988. An Introduction to Theoretical Geomorphology. Boston: Unwin Hyman. 
Tonkin, P. J. and Basher, L. R. 1990. Soil Stratigraphic Techniques in the Study of Soil and Landform Evolution Across the Southern Alps, New Zealand. In Soils and Landscape Evolution: Proceedings of the 21st Annual Binghampton Geomorphology Symposium, ed. P. L. K. Kneupfer and L. D. MCFadden, pp. 547-575. Amsterdam: Elsevier.

Troll, C. 1972. The Three-Dimensional zonation of the Himalayan Systems. In Geoecology of the High Mountain Regions of Eurasia, ed. C. Troll. pp.264-275. Weisbaden: Steiner-Verlag.

- 1973. High Mountain Belts Between the Polar Caps and the Equator: Their Definition and Lower Limit. Arctic and Alpine Research 5(3):A19-A27.

Ugolini, F. C., Reanier, R. E., Rau, G. H. and Hedges, J. I. 1981. Pedological, Isotopic and Geochemical Investigations of the Soils at the Boreal Forest and Alpine Tundra Transition in Northern Alaska. Soil Science $131(6): 359-374$

USDA. 1972. Soil Survey Laboratory Methods and Procedures for Collecting Soil Samples. USDA Soil Conservation Service, Soil Survey Illustrations Report No.1, Procedure $8 \mathrm{Cla}$ and $8 \mathrm{c} 1 \mathrm{e}$.

USDAFS. 1994. The Glacier Lakes Ecosystem Experiments Site. Rocky Mountain Forest and Range Experiment Station. General Technical Report RM-249. Washington D.C.

USDASCS. 1986. General Soil Map: State of Oregon.

Wardle, P. 1974. Alpine Timberlines. In Arctic and Alpine Environments, ed. J. D. Ives and R. G. Barry. pp.371402. London: Methuen and Company Ltd.

Weis, P. L., Gualtieri, Cannon, W. F., Tuchek, E. T., McMahan, A. B. and Federspiel, F. E. 1976. Mineral Resources of the Eagle Cap Wilderness and Adjacent Areas, Oregon; with a Section on Aeromagnetic Survey by W. F. Davis. USGS Bulletin. 1385E, E1-E100. 
APPENDIX A

SOIL DESCRIPTIONS 


\title{
WALLOWA MOUNTAINS SOIL DESCRIPTION
}

\author{
MAPPING UNIT: EAGLE CAP (1EC) \\ DATE DESCRIBED: Aug. 22, 1994 \\ ELEVATION: $\quad 2,918 \mathrm{~m}$ \\ LOCATION: Summit Eagle Cap
} CLASSIFICATION: Lithic Haplocryand QUADRANGLE: Eagle Cap GEOMORPHIC SURFACE: SUmmit CLIMATIC ZONE: Alpine LITHOLOGY: Granodiorite SLOPE/ASPECT: $5^{\circ}, \mathrm{SW}$ VEGETATION: Pinus albicaulis krummholz

COMMENTS: $\quad 2$ centimeter maximum organic covering on surface, angular, micaceous particles in profile, grus covering surface, more angular and less organic content with depth. Large pieces of weathered parent material in profile.

\begin{tabular}{|c|c|c|c|c|c|c|c|c|c|c|c|c|c|}
\hline HORIZON & $\begin{array}{c}\text { DEPTH } \\
\text { CM. }\end{array}$ & $\begin{array}{r}\text { CO } \\
\text { (DRY) }\end{array}$ & $\begin{array}{l}\text { OR } \\
\text { (MOIST) }\end{array}$ & $z>2 \mathrm{~mm}$ & SAND 8 & SILT \& & CLAY \& & TEXTURE & $\begin{array}{l}\text { ORGANIC } \\
\text { CARBON } \&\end{array}$ & STRUCTURE & $\begin{array}{l}\mathrm{pH} 1: 1 \\
\text { water }\end{array}$ & 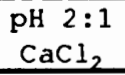 & $\begin{array}{l}\mathrm{NaF} \mathrm{pH} \\
2 \mathrm{~min} .\end{array}$ \\
\hline A & $0-2$ & $2.5 Y 6 / 4$ & $2.5 Y 3 / 2$ & 29.6 & 63.9 & 5 & 1.5 & LS & 3.2 & $\mathrm{sgfmgr}$ & 6.7 & 6.5 & 10 \\
\hline Rw & $2-8$ & $2.5 Y 6 / 3$ & $2.5 Y 3 / 2$ & 25.2 & 62.8 & 10 & 2 & LS & 1.2 & sgfmgr & 6.9 & 6.6 & 10.5 \\
\hline $\cos x$ & $8-45$ & $2.5 Y 6 / 4$ & $2.5 Y 4 / 4$ & 32.1 & 54.1 & 11 & 2.5 & $\mathrm{~s}$ & 0.8 & sefmigr & 7.2 & 6.6 & 10.1 \\
\hline
\end{tabular}




\section{WAIIOWA MOUNTAINS SOIL DESCRIPTION}

MAPPING UNIT: Eagle Cap (2EC) DATE DESCRIBED: Aug. 22, 1994 ELEVATION: 2,912m LOCATION: Summit Eagle Cap CLASSIFICATION: Lithic Dystric Cryochrept QUADRANGLE: Eagle Cap GEOMORPHIC SURFACE: Saddle CLIMATIC ZONE: Alpine LITHOLOGY: Granodiorite SLOPE/ASPECT: $20^{\circ}$, NNW VEGETATION: Alpine herbs and grasses

COMMENTS: Soll profile deeper than summit (IEC) and also fewer rocks in profile. No samples taken at this site.

$\begin{array}{lc}\text { HORIZON } & \text { DEPTH } \\ \text { A } & 0-8 \\ \text { BW } & 8-48\end{array}$




\section{WALIOWA MOUNTAINS SOIL DESCRIPTION}

MAPPING UNIT: Eagle Cap (3EC) DATE DESCRIBED: Aug. 22, 1994 ELEVATION: 2,869m LOCATION: mid-slope Eagle

CLASSIFICATION: Typic Haplocryand QUADRANGLE: Eagle Cap GEOMORPHIC SURFACE: SIOpe CLIMATIC zONE: Alpine

LITHOLOGY: Granodiorite SLOPE/ASPECT: $45^{\circ}$, NNW VEGETATION: heather, sedge, cushion plants, moss

COMMENTS: mafic float and granodiorite on slope movement, stone stripe area. high organic content, finer grains

intermixed with more angular ones.

\begin{tabular}{|c|c|c|c|c|c|c|c|c|c|c|c|c|c|}
\hline HORIZON & $\begin{array}{l}\text { DEPTH } \\
(\mathrm{cm})\end{array}$ & $\begin{array}{r}\mathrm{CO} \\
(\mathrm{DRY}) \\
\end{array}$ & $\begin{array}{l}\text { OR } \\
\text { (MOIST) }\end{array}$ & $8>2 \mathrm{~mm}$ & SAND $\%$ & SILT $\frac{8}{8}$ & CLAY \& & TEXTURE & $\begin{array}{l}\text { ORGANIC } \\
\text { CARBON } \&\end{array}$ & STRUCTURE & $\begin{array}{l}\mathrm{pH} 1: 1 \\
\text { water }\end{array}$ & $\begin{array}{c}\mathrm{pH} 2: 1 \\
\mathrm{CaCl}_{2}\end{array}$ & $\begin{array}{l}\mathrm{NaF} \mathrm{pH} \\
2 \mathrm{~min} .\end{array}$ \\
\hline A1 & $0-10$ & $2.5 Y 4 / 2$ & $10 Y R 2 / 2$ & 21.5 & 73 & 3.5 & 2 & LS & 3.9 & sgfmgr & 6.5 & 6.1 & 9.6 \\
\hline A2 & $10-16$ & $2.5 Y 4 / 4$ & $10 Y R 3 / 2$ & 19.1 & 75.7 & 3.2 & 2 & LS & 2.9 & sgfmgr & 6.6 & 6.1 & 10.4 \\
\hline A3 & $16-35$ & $2.5 Y 4 / 2$ & $10 Y R 2 / 2$ & 34.3 & 61.7 & 3 & 1 & LS & 3.4 & sgfmgr & 6.6 & 6.2 & 10.3 \\
\hline Bw1 & $35-52$ & $2.5 Y 5 / 4$ & 10YR3/4 & 31 & 59 & 8.5 & 1.5 & LS & 2.0 & sgfmgr & 6.9 & 6.3 & 10.7 \\
\hline Bw2/C & $52-85$ & $2.5 Y 6 / 4$ & $10 Y R 3 / 4$ & 41 & 52 & 5.5 & 1.5 & $s$ & 1.3 & sgmegr & 7.3 & 6.4 & 10.5 \\
\hline
\end{tabular}




\title{
WALIONA MOUNTAINS SOIL DESCRIPTION
}

MAPPING UNIT: Eagle Cap (4EC) DATE DESCRIBED: Aug. 22, 1994 ELEVATION: 2,829m LOCATION: lOwer slope Eagle
Cap

\begin{abstract}
CLASSIFICATION: Lithic Haplocryand QUADRANGLE: Eagle Cap GEOMORPHIC SURFACE: Slope CLIMATIC zONE: Alpine
\end{abstract}
LITHOLOGY: Basalt SLOPE/ASPECT: $35^{\circ}$, NNW VEGETATION: heather, sedge, cushion plants

COMMENTS: mafic dike, not as micaceous, reasonable organic content, finer grains intermixed with gritty angular ones.

\begin{tabular}{|c|c|c|c|c|c|c|c|c|c|c|c|c|c|}
\hline HORIZON & $\begin{array}{c}\text { DEPTH } \\
\text { CM. }\end{array}$ & $\begin{array}{c}c 0 \\
\text { (DRY) }\end{array}$ & $\begin{array}{l}\text { OR } \\
\text { (MOIST) }\end{array}$ & $8>2 \mathrm{~mm}$ & SAND $\%$ & SILT & CLAY \& & TEXTURE & $\begin{array}{l}\text { ORGANIC } \\
\text { CARBON } 8\end{array}$ & STRUCTURE & $\begin{array}{l}\mathrm{pH} 1: 1 \\
\text { water }\end{array}$ & $\begin{array}{c}\mathrm{pH} 2: 1 \\
\mathrm{CaCl}_{2}\end{array}$ & $\begin{array}{l}\mathrm{NaF} \mathrm{pH} \\
2 \mathrm{~min} .\end{array}$ \\
\hline A & $0-9$ & $2.5 \times 4 / 2$ & $10 \mathrm{YR} 2 / 2$ & 6.4 & 86.6 & 5 & 2 & $\mathrm{SL}$ & 3.8 & $\mathrm{sgfm}$ & 6.2 & 6.0 & 9.9 \\
\hline Bw1 & $9-28$ & $2.5 Y 4 / 4$ & 10YR3/3 & 28.8 & 66.7 & 2.5 & 2 & $\mathrm{LS}$ & 2.8 & $\mathrm{sgfm}$ & 6.6 & 6.2 & 10.6 \\
\hline $\mathrm{BW} 2 / \mathrm{C}$ & $28-40$ & $2.5 Y 5 / 4$ & 10YR3/4 & 39.4 & 53.6 & 5.5 & 1.5 & $\mathrm{~s}$ & 1.8 & sqm & 7.2 & 6.4 & 10.8 \\
\hline
\end{tabular}




\section{WALIOWA MOUNTAINS SOII DESCRIPTION}

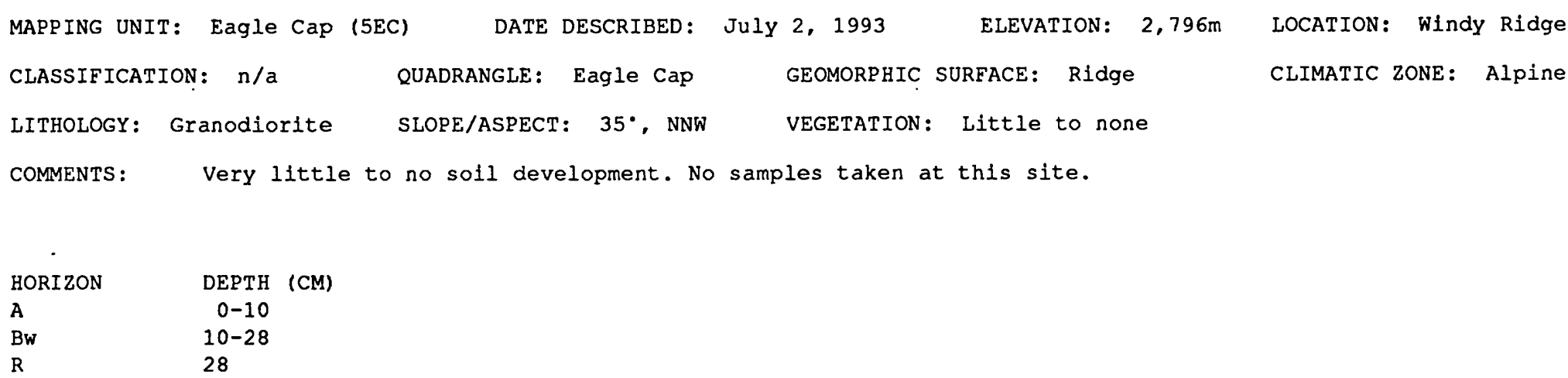




\section{WAILOWA MOUNTAINS SOIL DESCRIPTION}

MAPPING UNIT: Matterhorn (IMH) DATE DESCRIBED: Oct. 9, 1994 ELEVATION: 2,996m LOCATION: Summit Matterhorn

CLASSIFICATION: n/a QUADRANGLE Eagle Cap GEOMORPHIC SURFACE: Summit CLIMATIC zONE: Alpine

LITHOLOGY: Marble (dirty calcite) SLOPE/ASPECT: $2 \cdot$, W VEGETATION: A few alpine mat plants

COMMENTS: Very little to no soil development, other than apparent eolian influx. Very angular, single-grained, marble fragments. Poorly developed B2/C1 over C2 horizon

\begin{tabular}{|c|c|c|c|c|c|c|c|c|c|c|c|c|c|}
\hline HORIZON & $\begin{array}{l}\text { DEPTH } \\
(\mathrm{cm})\end{array}$ & ${ }^{c 0}{ }^{c 0}$ & $\begin{array}{l}\text { LOR } \\
\text { (MOIST) }\end{array}$ & $q>2 \mathrm{~mm}$ & SAND 8 & SILT 8 & CLAY \& & TEXTURE & $\begin{array}{l}\text { ORGANIC } \\
\text { CARBON } 8 \\
\end{array}$ & STRUCTURE & $\begin{array}{c}\mathrm{pH} 1: 1 \\
\text { water }\end{array}$ & $\begin{array}{c}\mathrm{pH} \quad 2: 1 \\
\mathrm{CaCl}\end{array}$ & $\begin{array}{l}\mathrm{NaF} \mathrm{pH} \\
2 \mathrm{~min} .\end{array}$ \\
\hline C1 & $0-10$ & $2.5 Y 6 / 2$ & $10 Y R 6 / 2$ & 17.25 & 80.4 & 1.35 & 1.0 & $S$ & 0.9 & sgcgr & 7.3 & 5.8 & 9.9 \\
\hline $\mathrm{C} 2$ & $10-25$ & $10 Y R 7 / 1$ & $10 Y R 6 / 2$ & 20.9 & 78.1 & 0.7 & 0.3 & $\mathrm{~s}$ & 0.7 & sggr & 7.1 & 6.1 & 9.9 \\
\hline
\end{tabular}




\section{WALLOWA MOUNTAINS SOIL DESCRIPTION}

MAPRING UNIT: Matterhorn (2MH) DATE DESCRIBED: Oct. 9, 1994 ELEVATION: 2,890m LOCATION: TOe SlOpe
CLASSIFICATION : n/a
QUADRANGLE: Eagle Cap
GEOMORPHIC SURFACE: Arete CLIMATIC ZONE: Alpine

LITHOLOGY: Marble (dirty calcite) SLOPE/ASPECT: $2^{\circ}, \mathrm{N} \quad$ VEGETATION: A few alpine mat plants

COMMENTS: Very little to no soil development, other than apparent eolian influx, especially visible in surficial

deposits. Very angular, single-grained, marble fragments. Low organic matter content. Poorly developed c1

over $\mathrm{C} 2$ horizon

\begin{tabular}{|c|c|c|c|c|c|c|c|c|c|c|c|c|c|}
\hline HORIZON & $\begin{array}{l}\text { DEPTH } \\
(\mathrm{cm})\end{array}$ & $\begin{array}{r}{ }^{C O} \\
\text { (DRY) }\end{array}$ & $\begin{array}{l}\text { OR } \\
\text { (MOIST) }\end{array}$ & $8>2 \mathrm{~mm}$ & SAND 8 & SILT 8 & CLAY \& & TEXTURE & $\begin{array}{l}\text { ORGANIC } \\
\text { CARBON } \frac{8}{8}\end{array}$ & STRUCTURE & $\begin{array}{l}\mathrm{pH} 1: 1 \\
\text { water }\end{array}$ & $\begin{array}{c}\mathrm{pH} \quad 2: 1 \\
\mathrm{CaCl}_{2}\end{array}$ & $\begin{array}{l}\mathrm{NaF} \mathrm{pH} \\
2 \mathrm{~min} .\end{array}$ \\
\hline $\mathrm{Cl}$ & $0-10$ & $2.5 Y 6 / 2$ & $2.5 Y 5 / 2$ & 3.1 & 79.9 & 15.0 & 2.0 & LS & 1.2 & sgmgr & 6.7 & 6.5 & 10.2 \\
\hline$C 2$ & $10-30$ & $2.5 Y 2 / 1$ & $2.5 Y 1 / 1$ & 4.1 & 92.9 & 0.5 & 2.5 & $\mathrm{~s}$ & 0.4 & $g r$ & 6.8 & 6.5 & 10.1 \\
\hline
\end{tabular}




\title{
WALLOWA MOUNTAINS SOIL DESCRIPTION
}

\author{
MAPPING UNIT: Sacajawea (SA) \\ DATE DESCRIBED: Oct. 9, 1994 \\ ELEVATION: $\quad 2,999 \mathrm{~m}$ \\ LOCATION: Summit Sacajawea \\ CLASSIFICATION: . n/a \\ QUADRANGLE: Eagle Cap \\ GEOMORPHIC SURFACE: SUmmit \\ CLIMATIC ZONE: Alpine \\ LITHOLOGY: Argillite \\ SLOPE/ASPECT: $3^{\circ}, \mathrm{N}$ \\ VEGETATION: A few alpine mat plants
}

COMMENTS: Little to no soil development, other than surficial covering of eolian sediments that have been intermixed. Dark "solls", angular, granular, weathered parent material.

\begin{tabular}{|c|c|c|c|c|c|c|c|c|c|c|c|c|c|}
\hline HORIZON & $\begin{array}{c}\text { DEPTH } \\
(\mathrm{cm}) \\
\end{array}$ & $\begin{array}{c}{ }^{C O} \\
\text { (DRY) }\end{array}$ & $\begin{array}{l}\text { OR } \\
\text { (MOIST) }\end{array}$ & $8>2 \mathrm{~mm}$ & SAND 8 & SILT 8 & CLAY 8 & TEXTURE & $\begin{array}{l}\text { ORGANIC } \\
\text { CARBON } 8 \\
\end{array}$ & STRUCTURE & $\begin{array}{l}\mathrm{pH} 1: 1 \\
\text { water }\end{array}$ & $\begin{array}{l}\mathrm{pH} 2: 1 \\
\mathrm{CaCl}_{2}\end{array}$ & $\begin{array}{l}\mathrm{NaF} p H \\
2 \min .\end{array}$ \\
\hline $\mathrm{Cl}$ & $0-2$ & $2.5 Y 5 / 3$ & $10 \mathrm{YR} 3 / 3$ & 25.2 & 54.8 & 14 & 6 & LS & 0.4 & fgr & 6.8 & 6.6 & 10 \\
\hline $\mathrm{C} 2$ & $2-10$ & $2.5 Y 5 / 4$ & $10 Y R 3 / 4$ & 33.3 & 48.7 & 14 & 4 & $\mathrm{~L}$ & 0.7 & $\mathrm{vf}$ & 6.7 & 6.6 & 9.9 \\
\hline$c 3$ & $10-15$ & $2.5 Y 4 / 2$ & $10 \mathrm{YR} 2 / 2$ & 51.4 & 35.1 & 11 & 2.5 & LS & 0.7 & $g r$ & 7.1 & 6.6 & 9.7 \\
\hline
\end{tabular}


APPENDIX B

CUMULATIVE FREQUENCY CURVES 


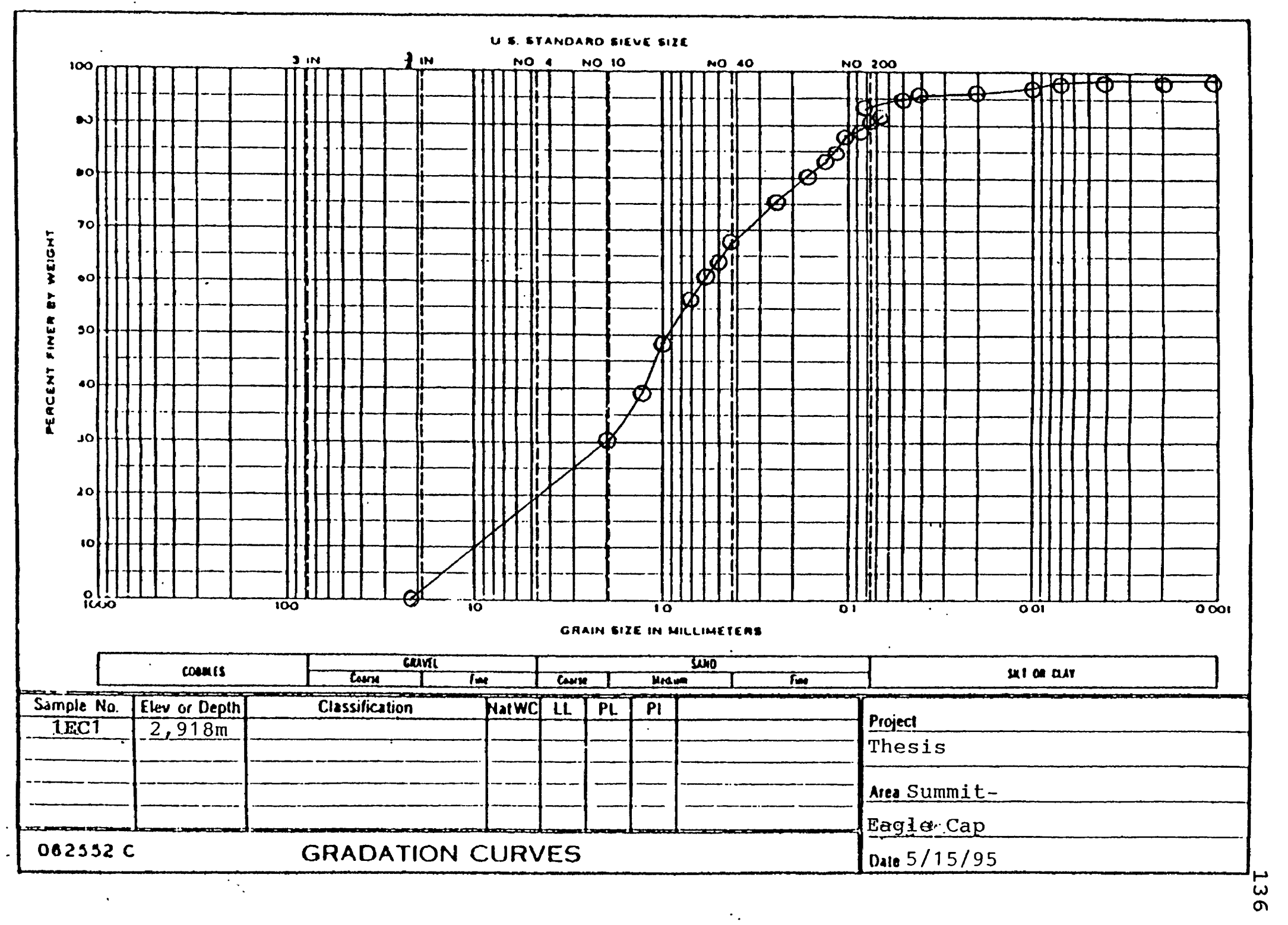




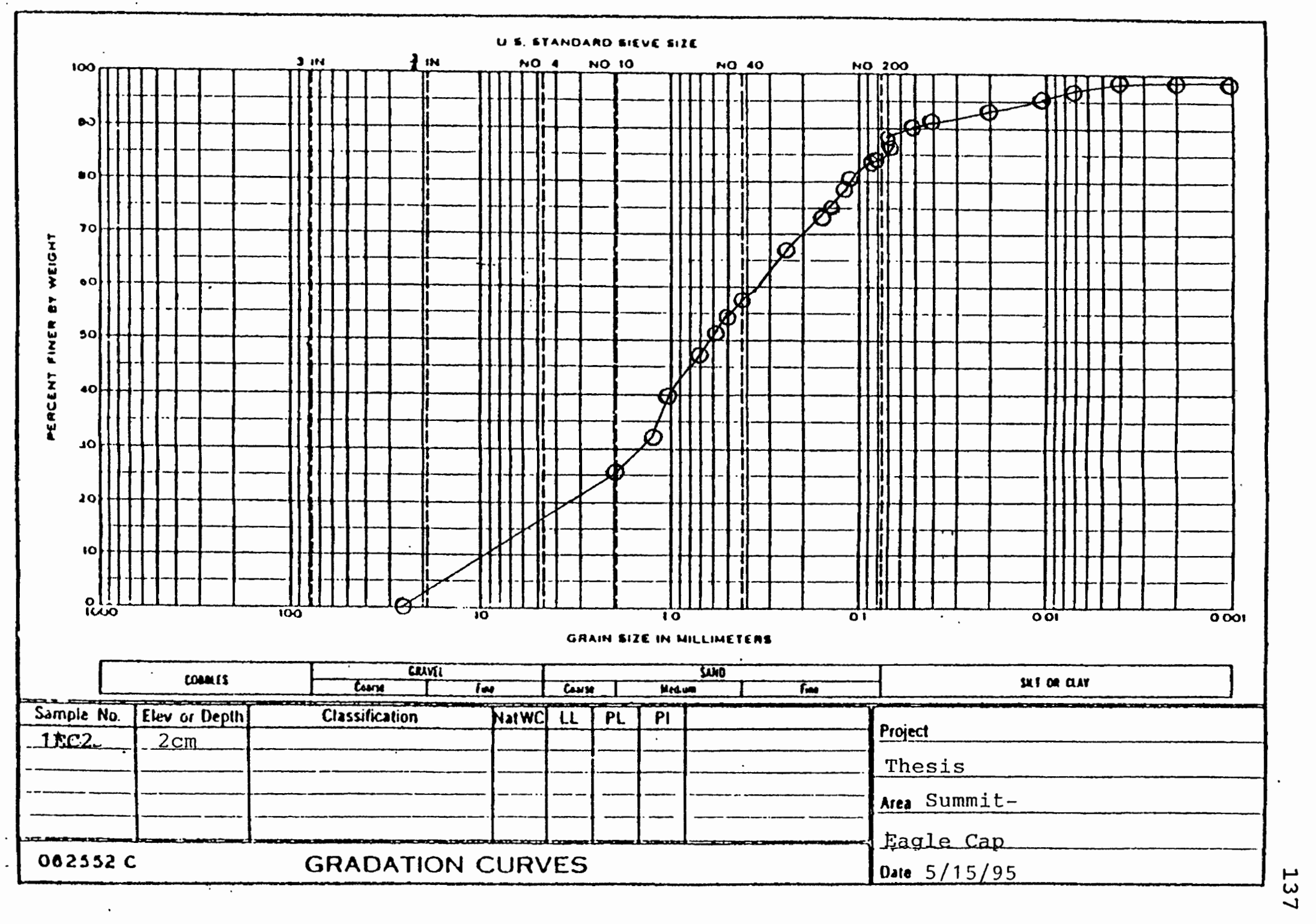




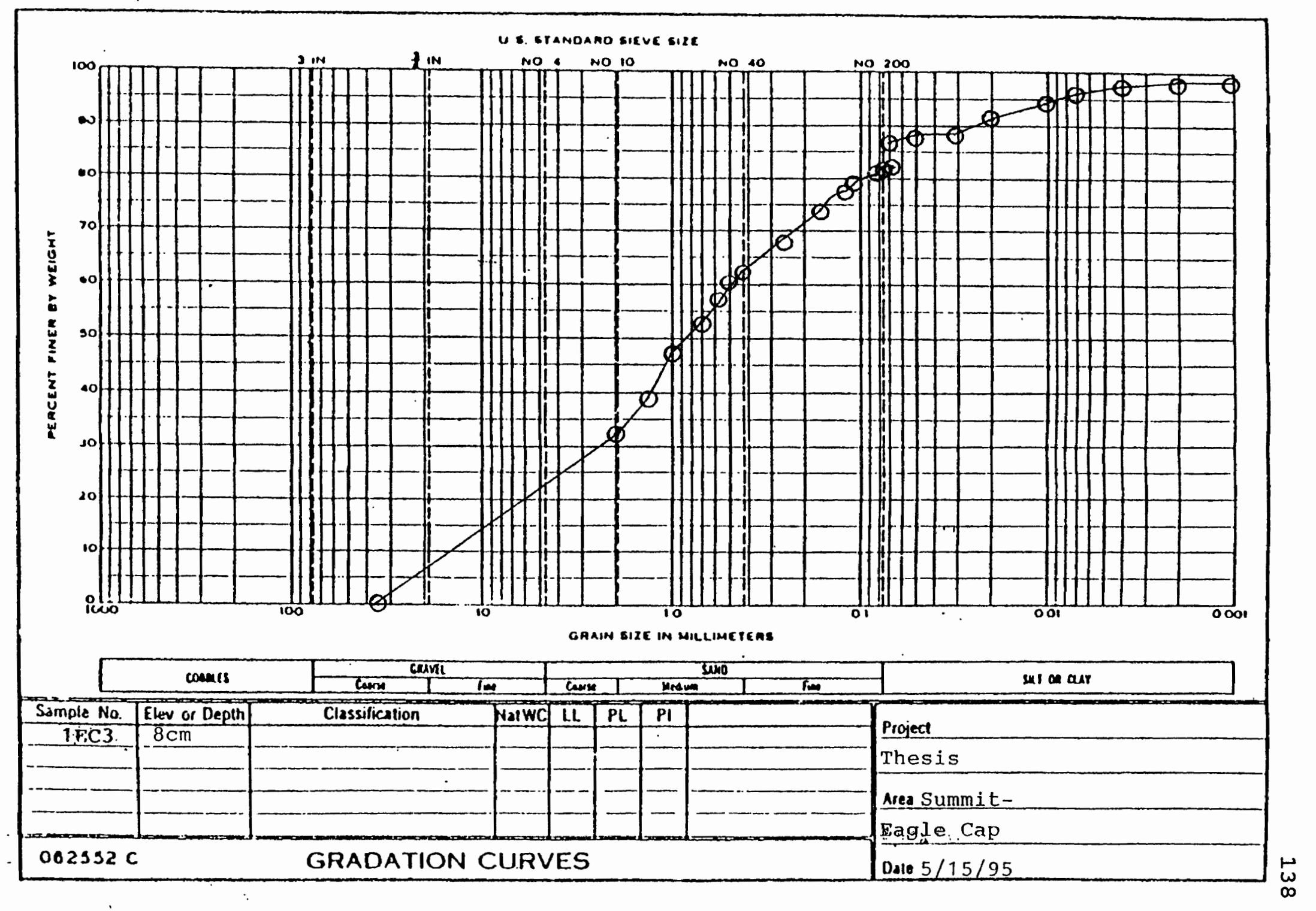




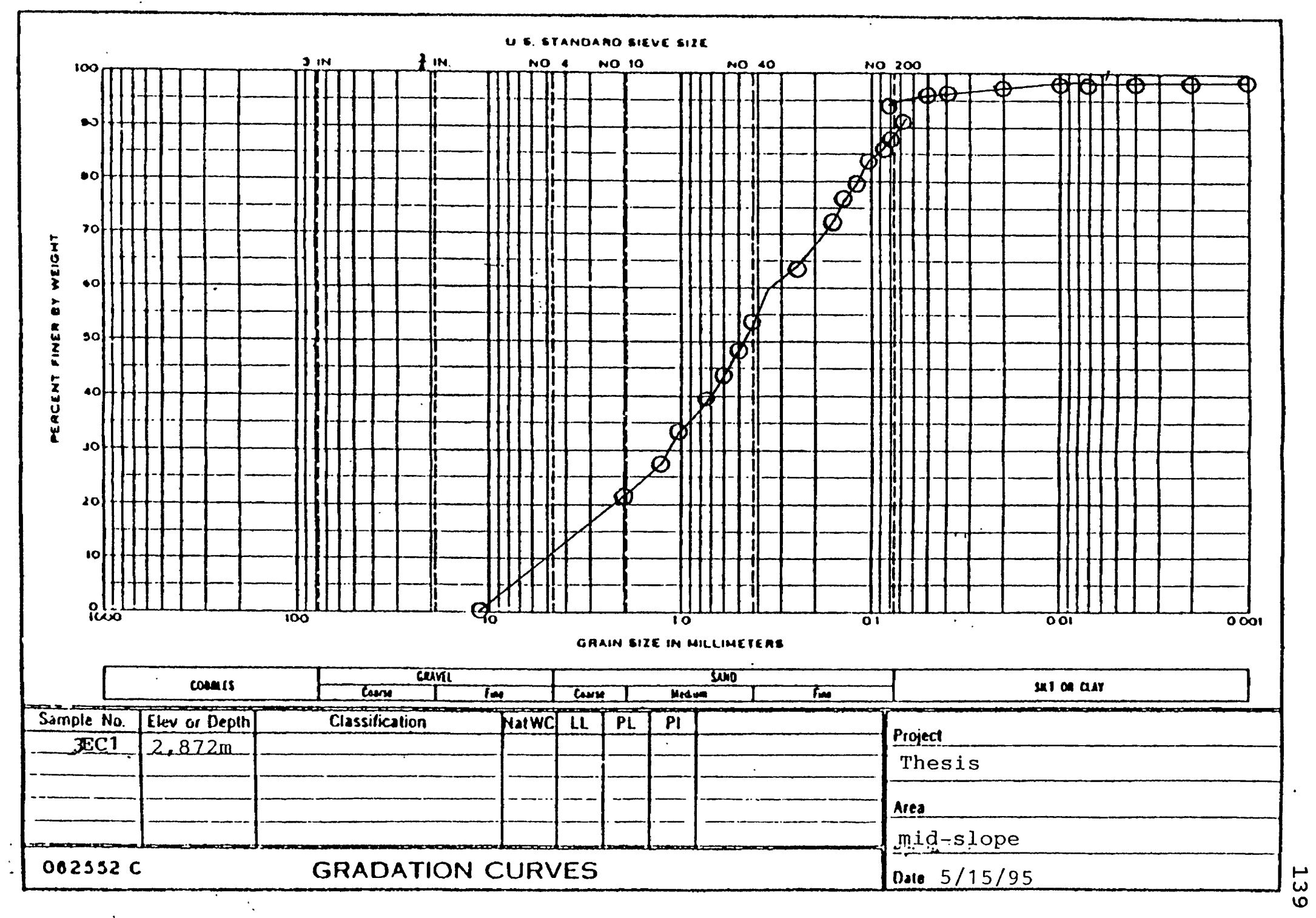




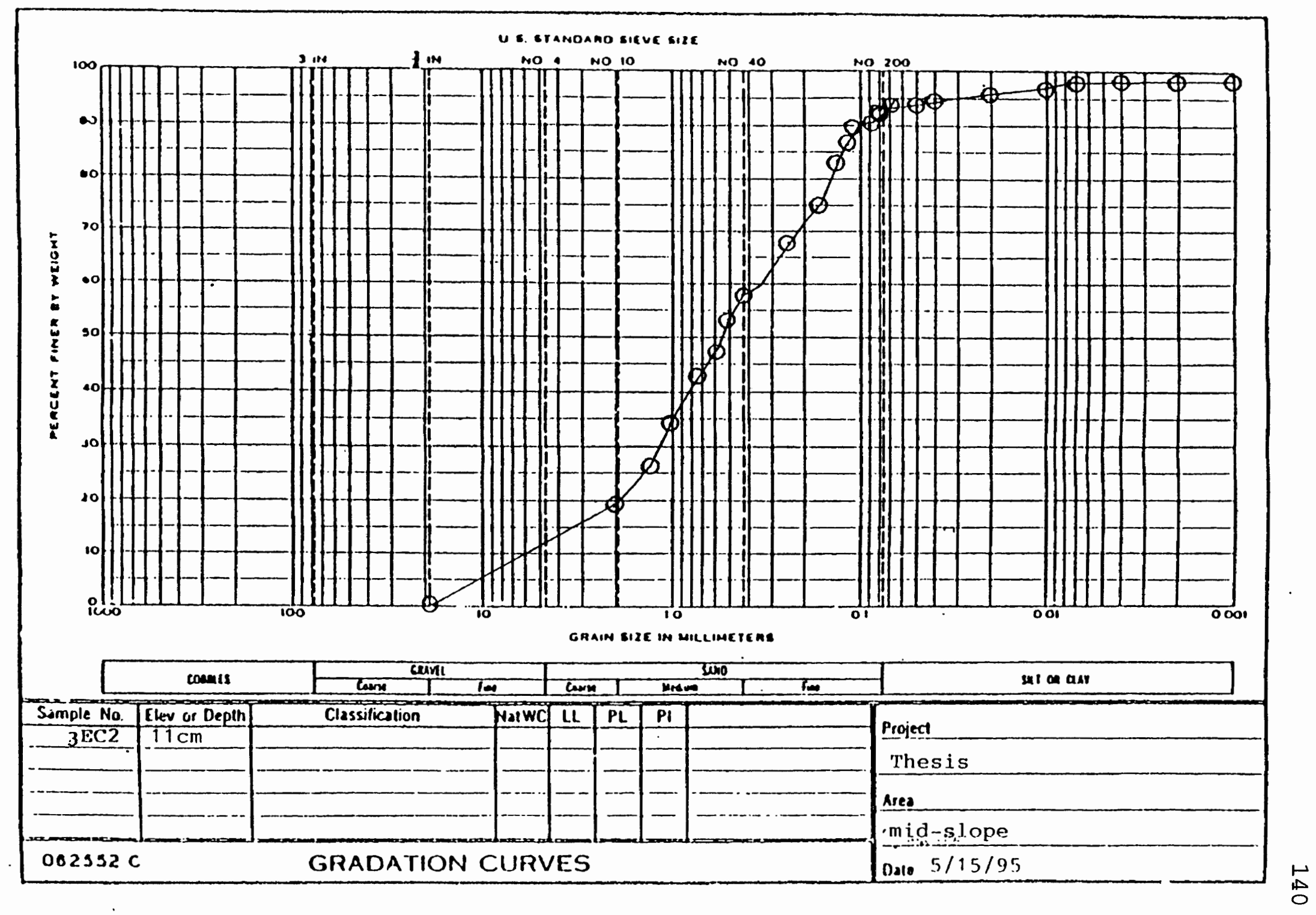




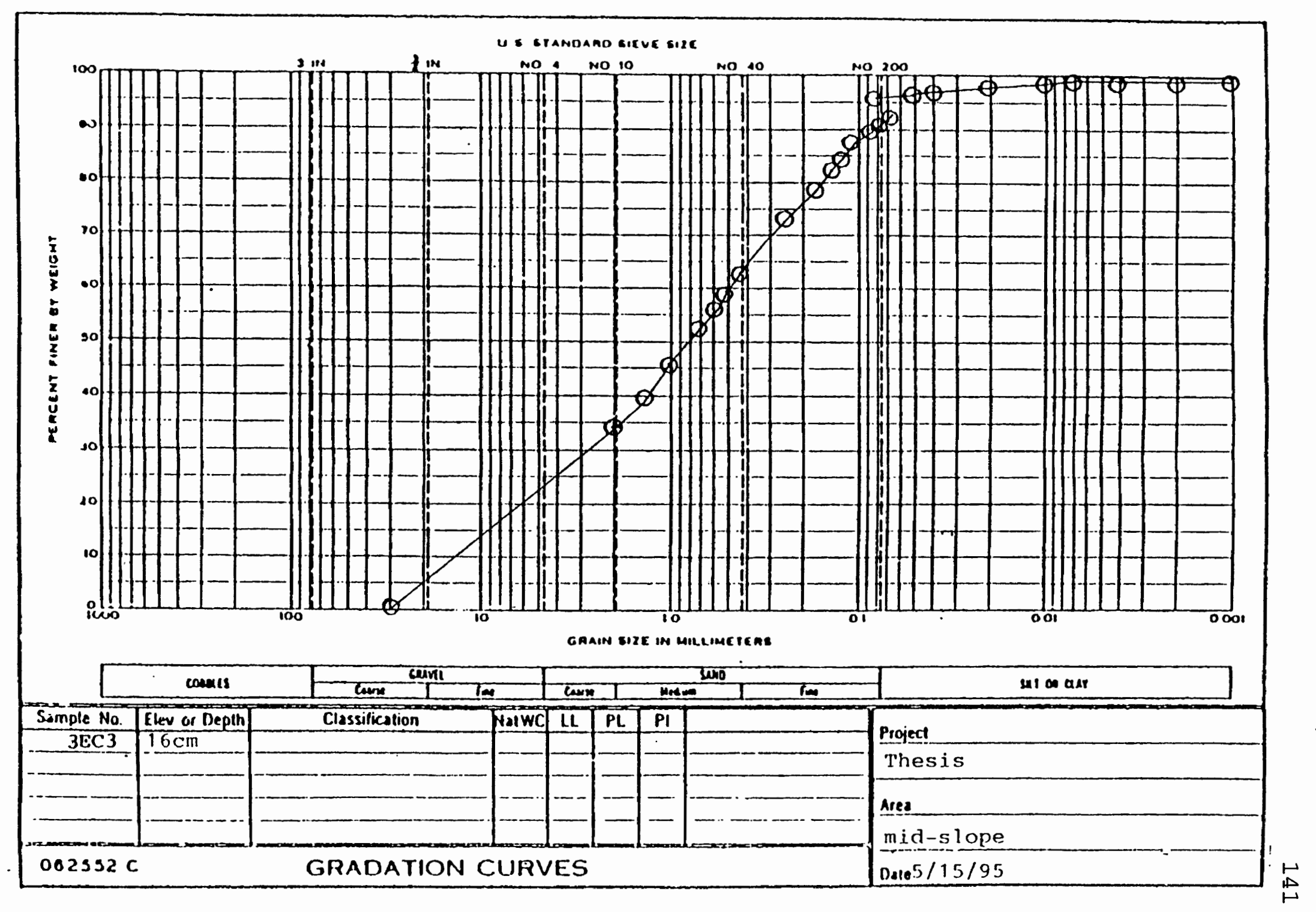




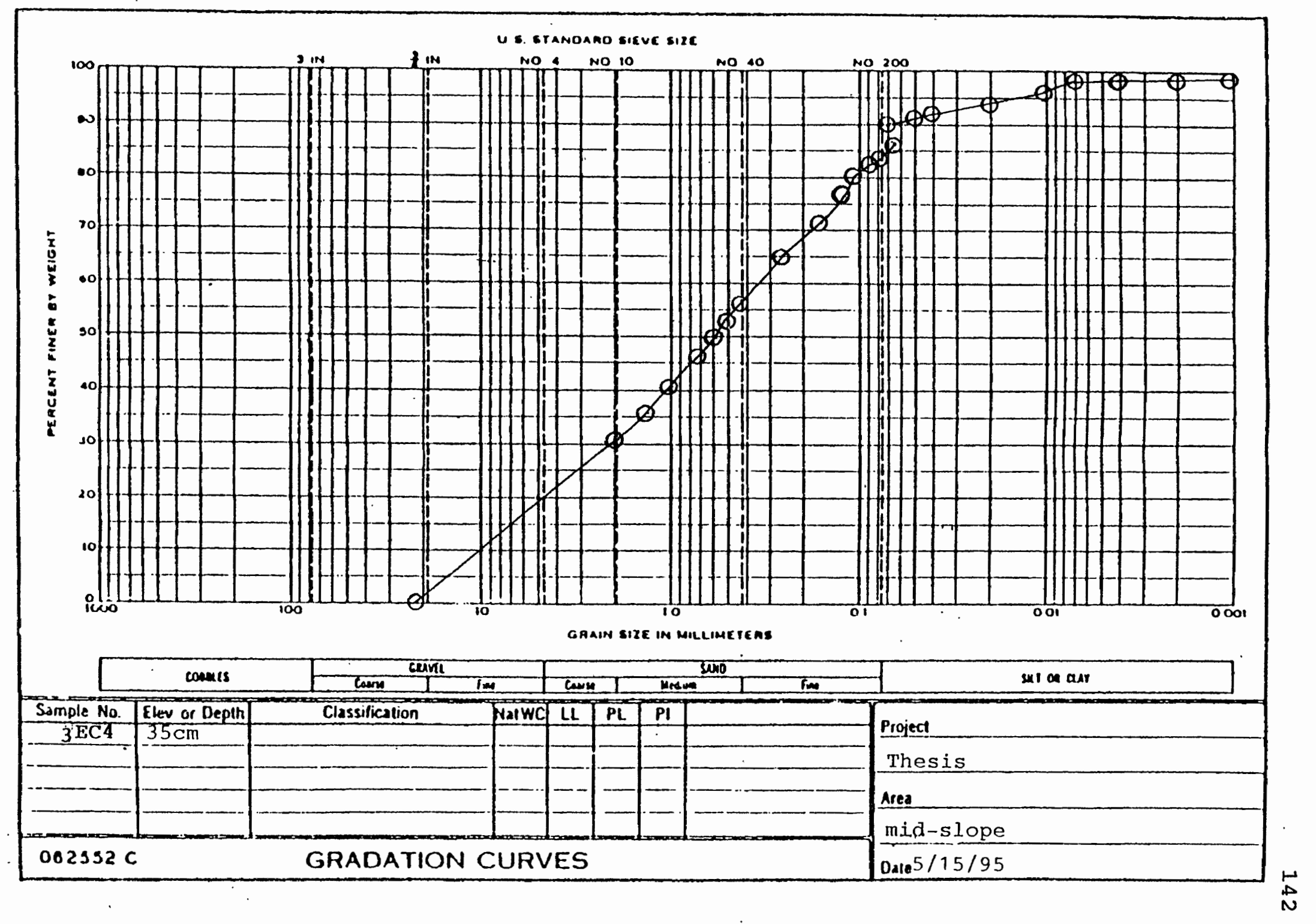




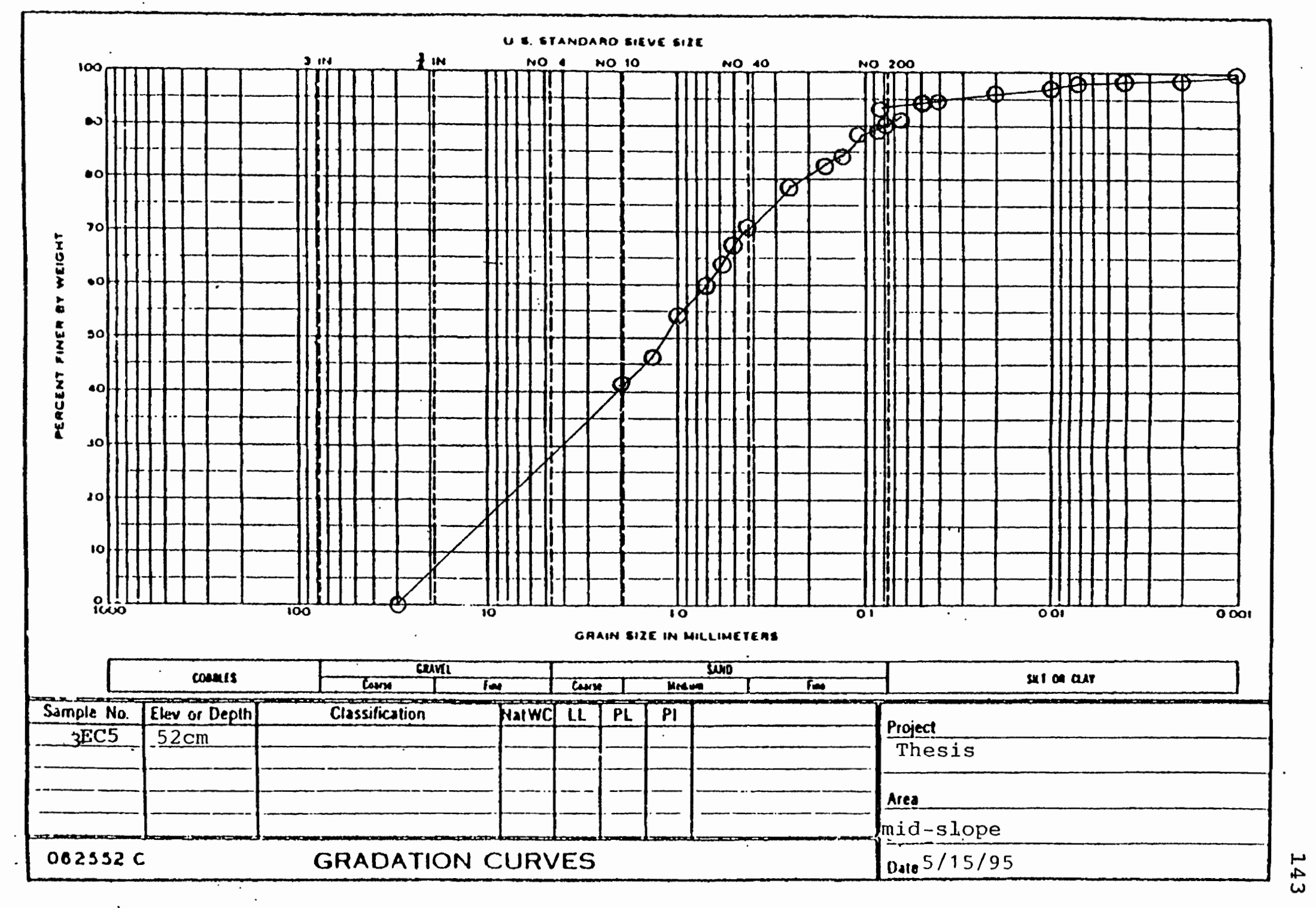




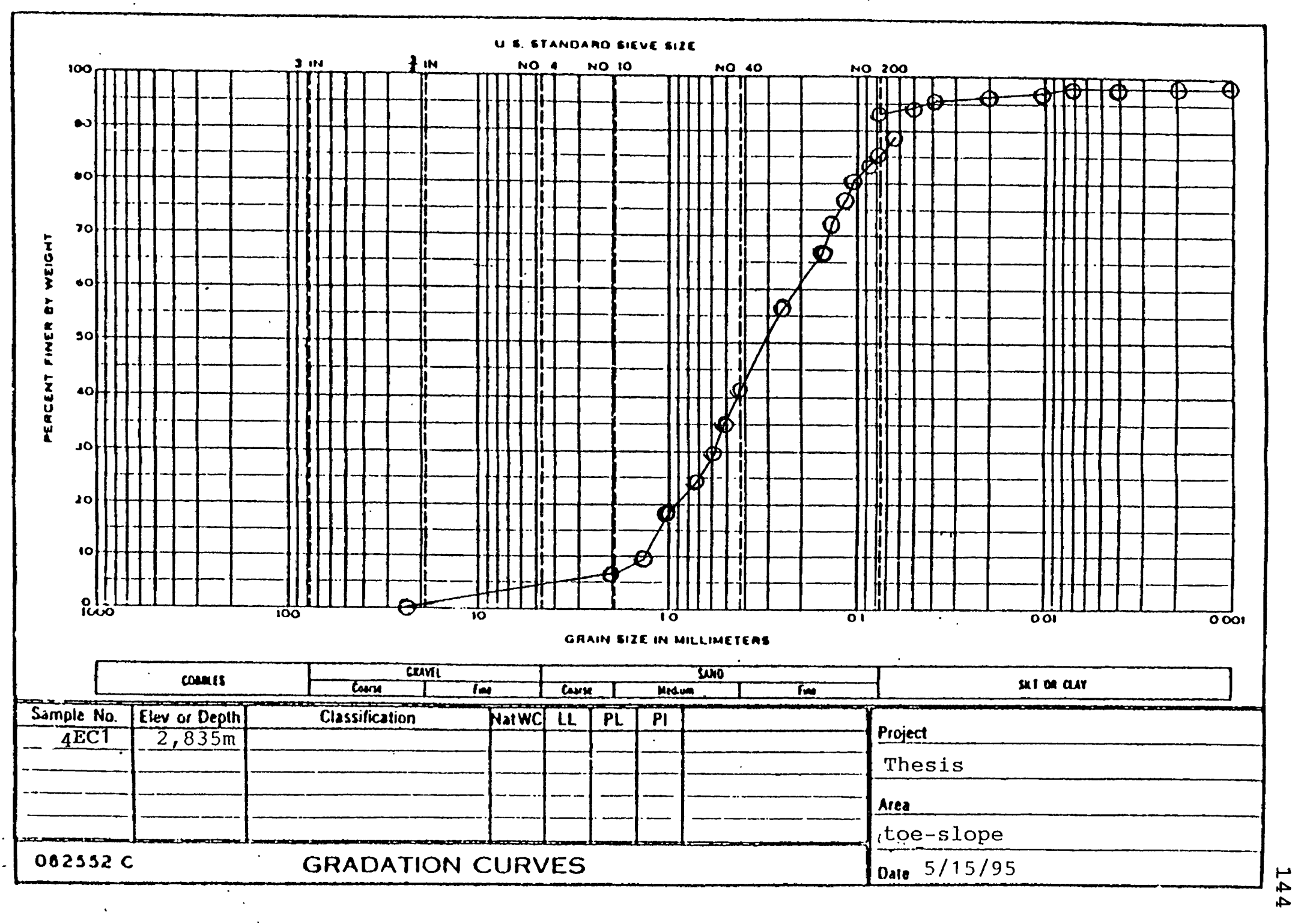




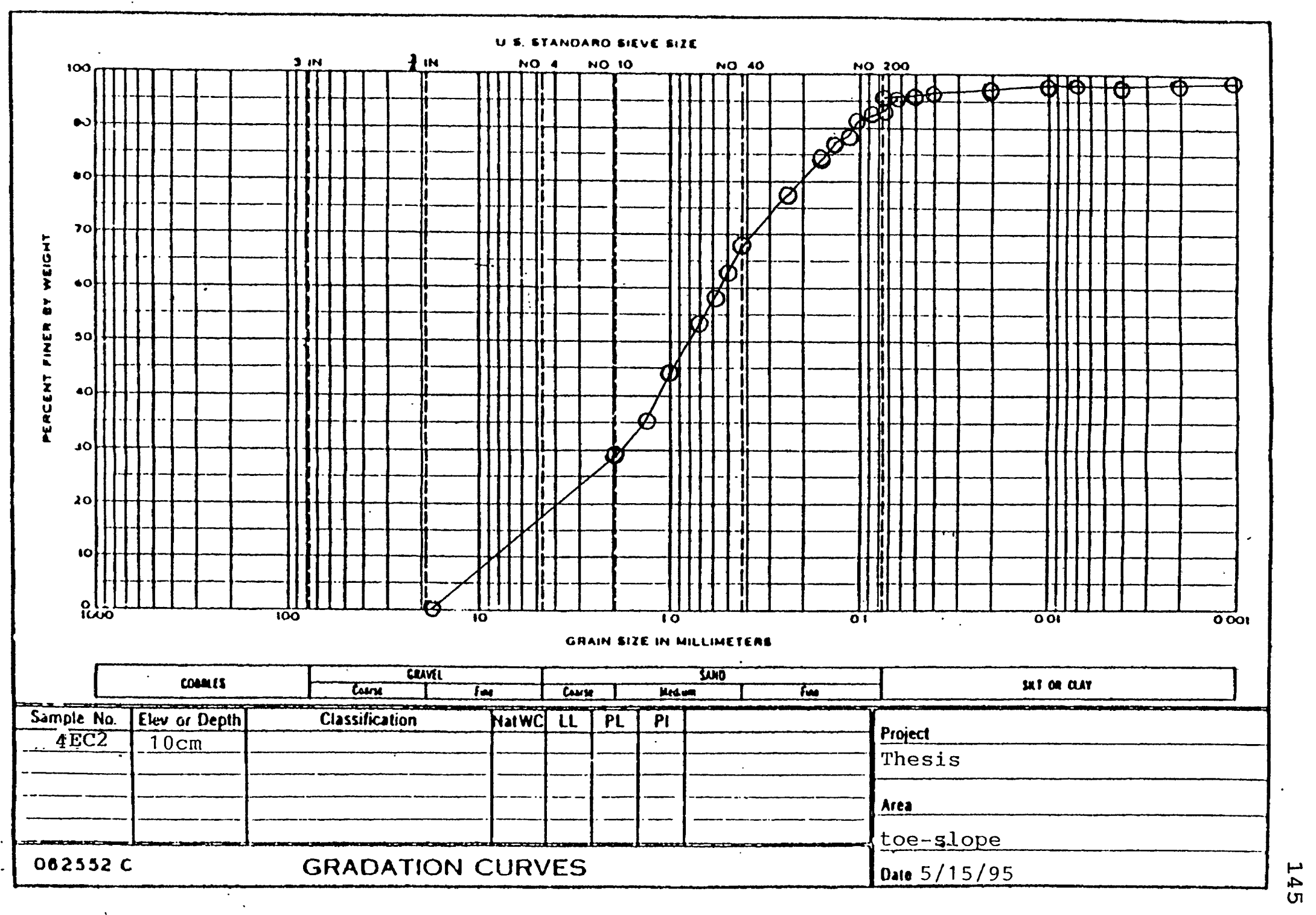




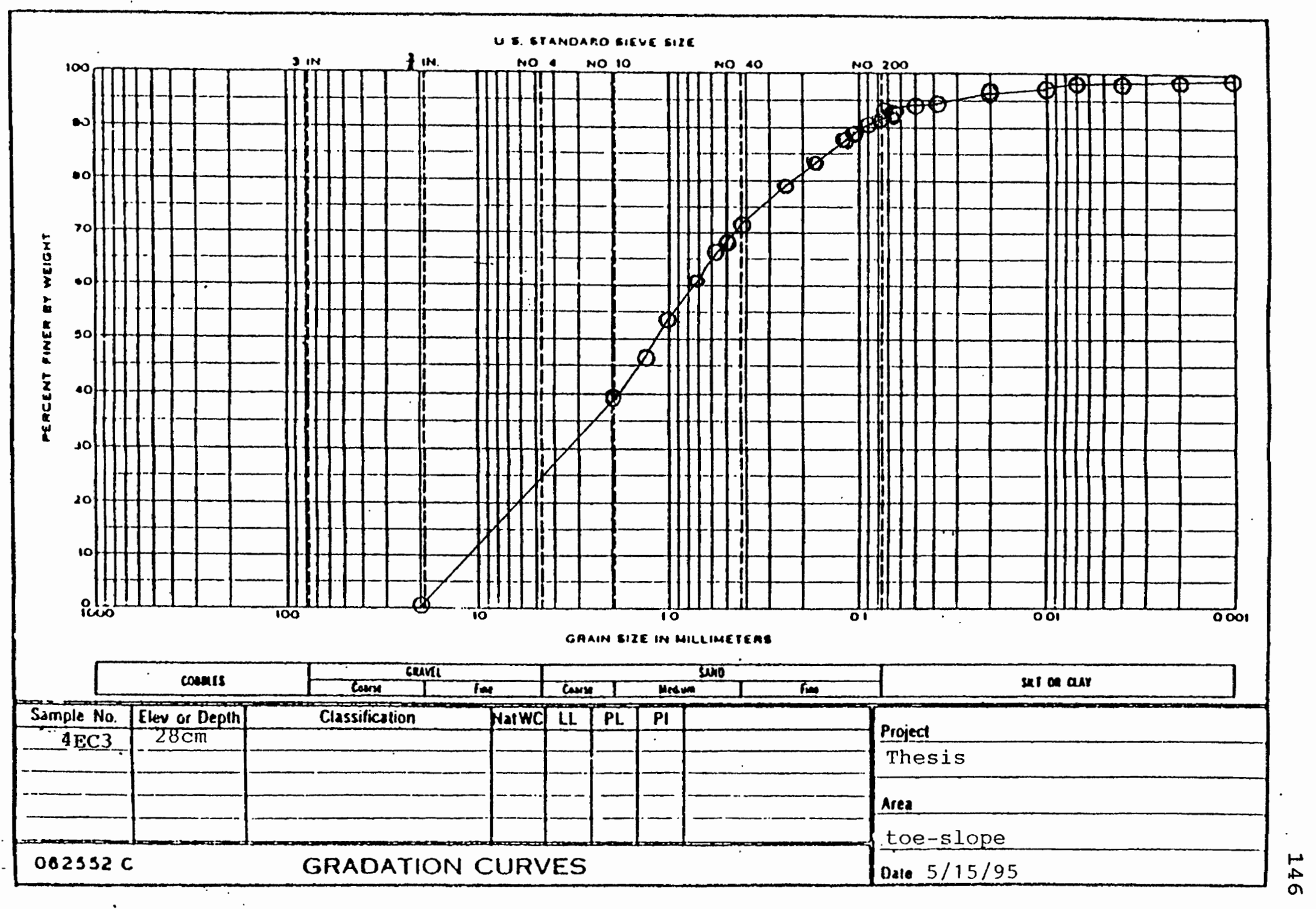




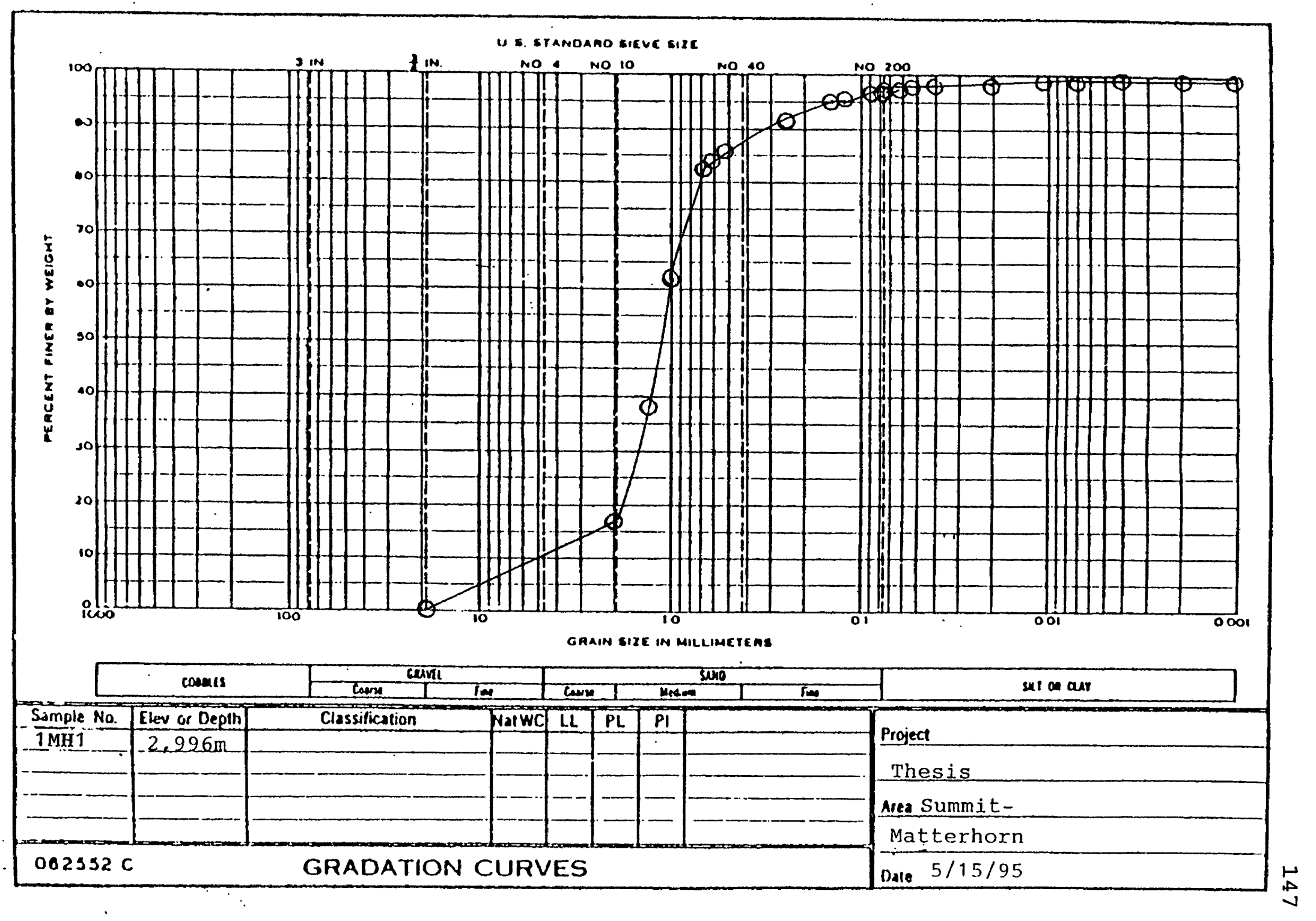




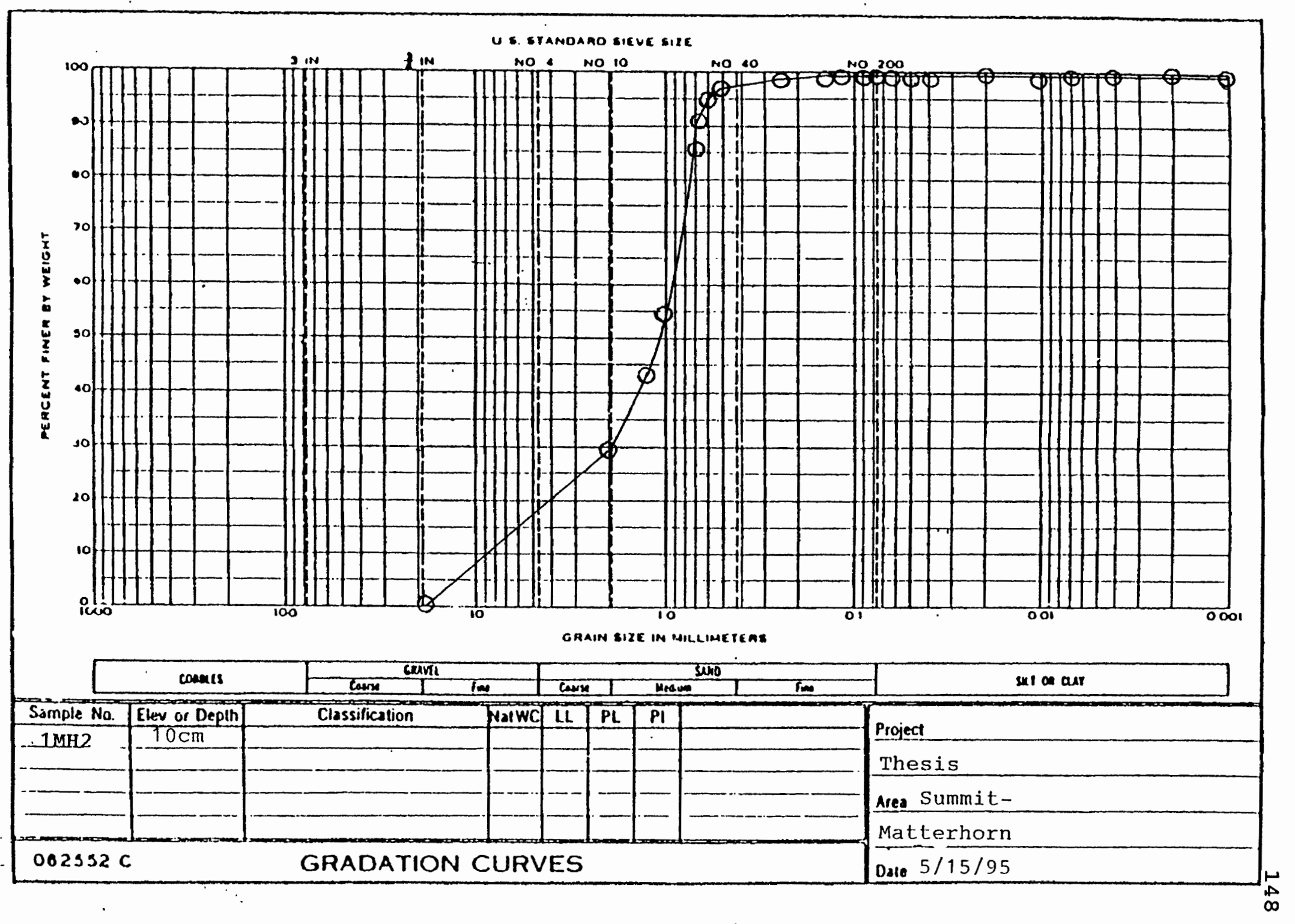




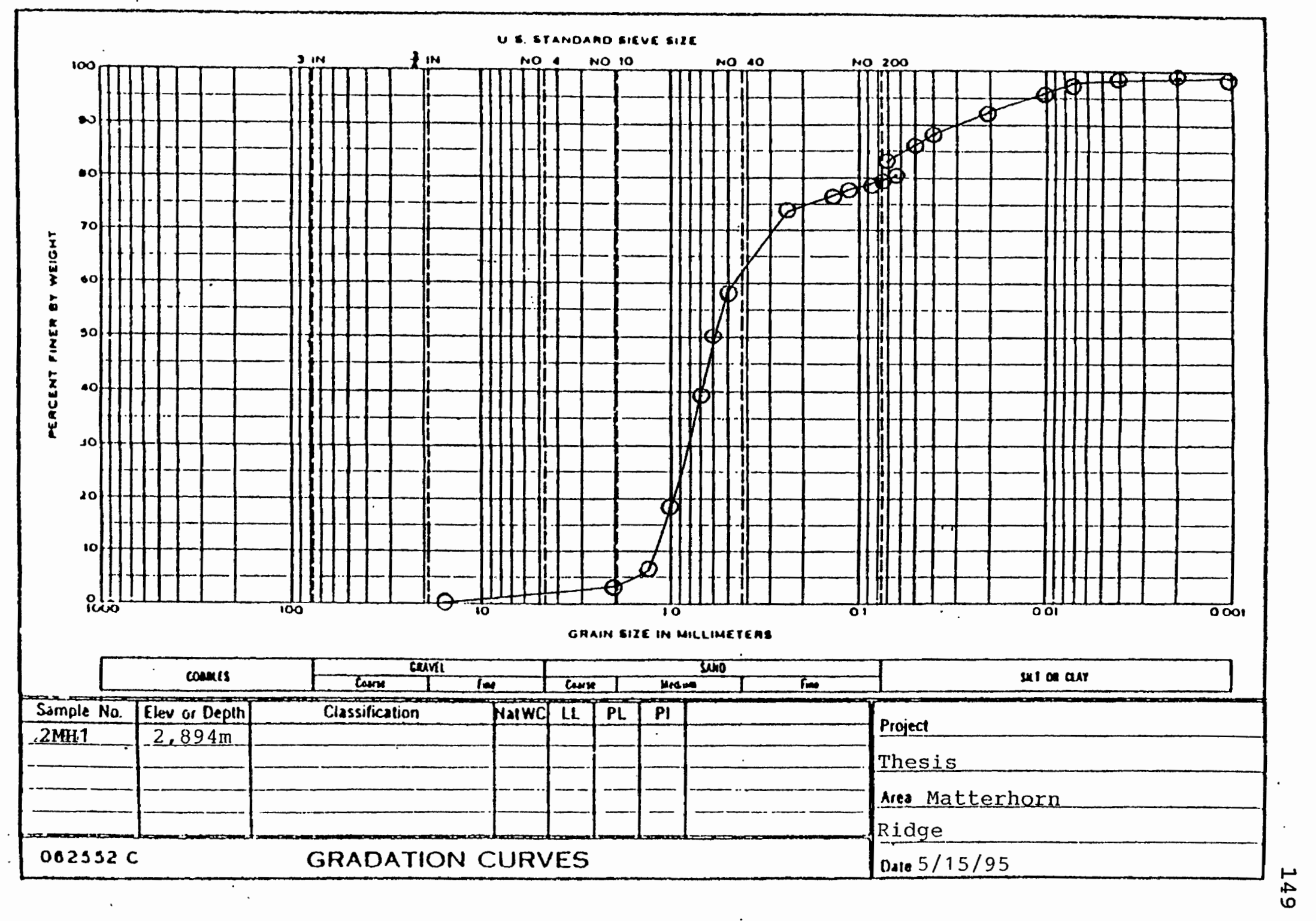




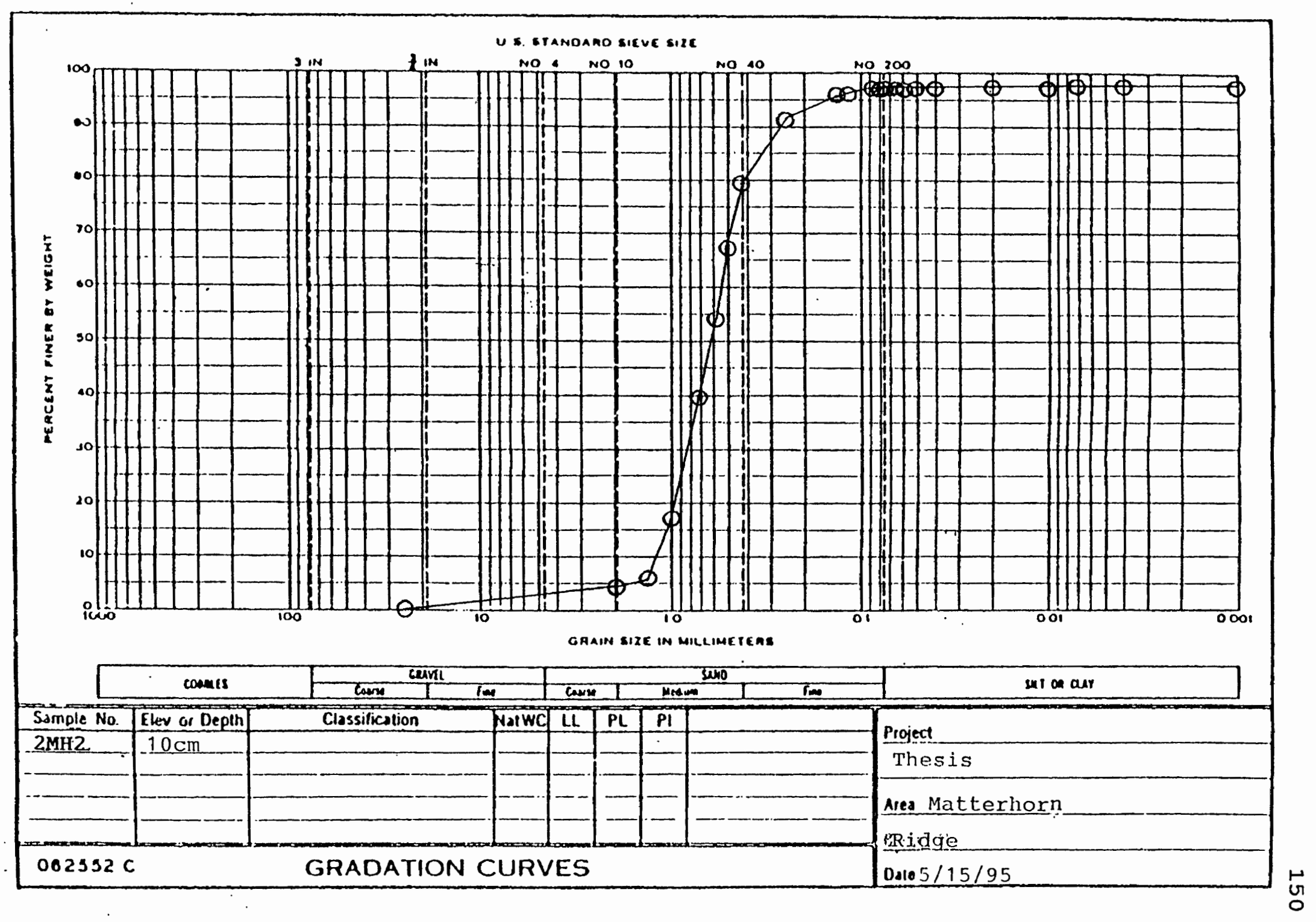




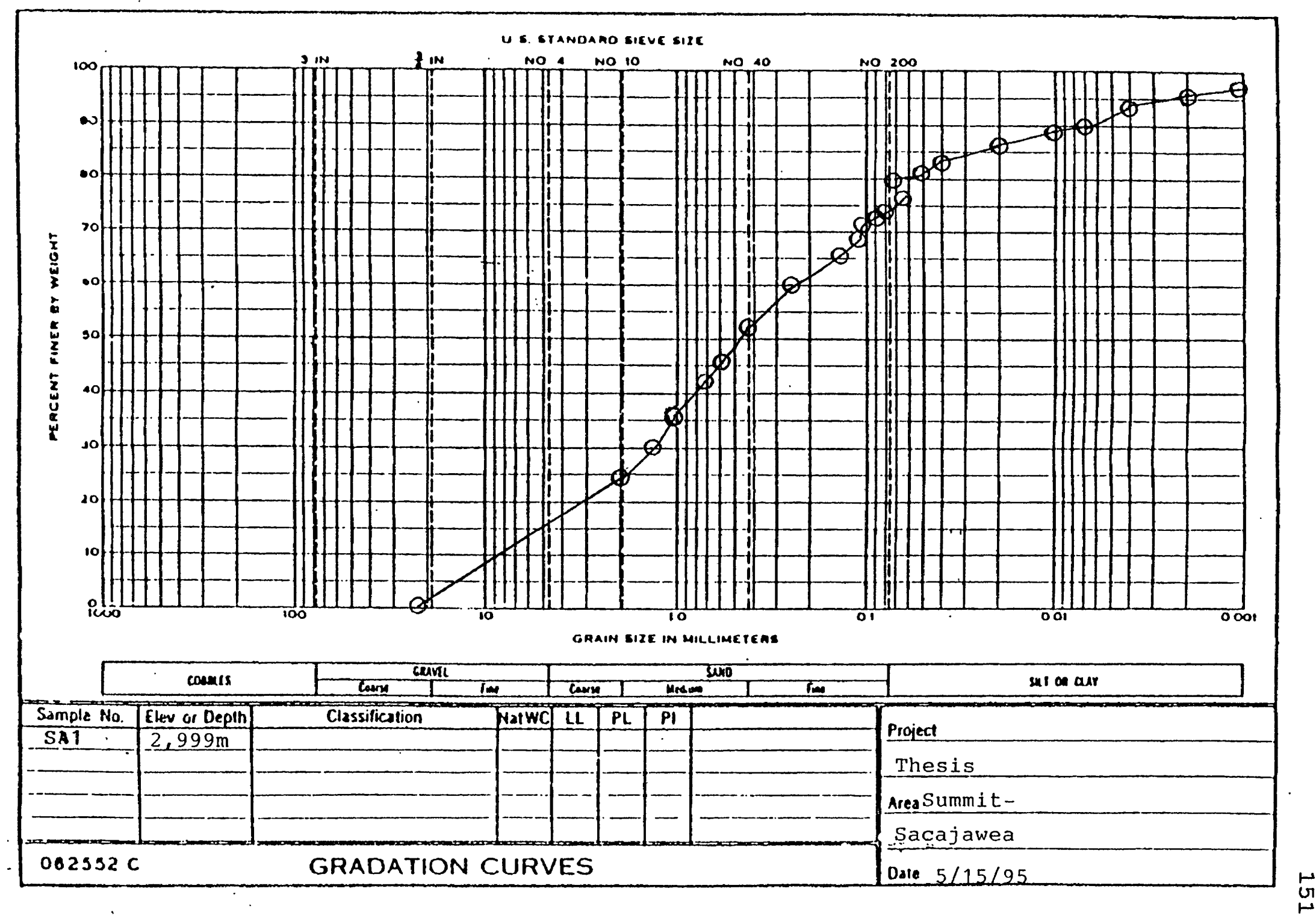




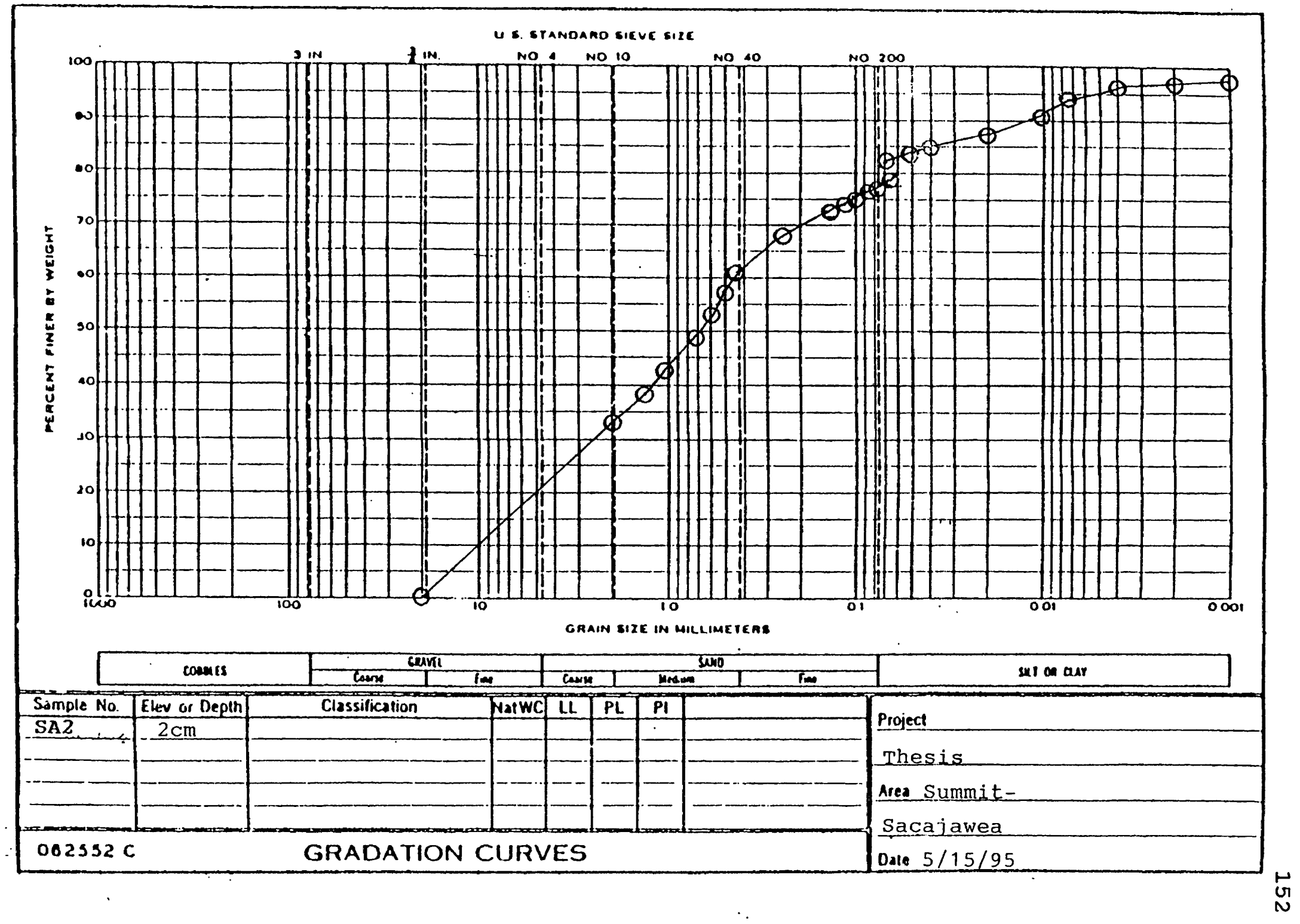




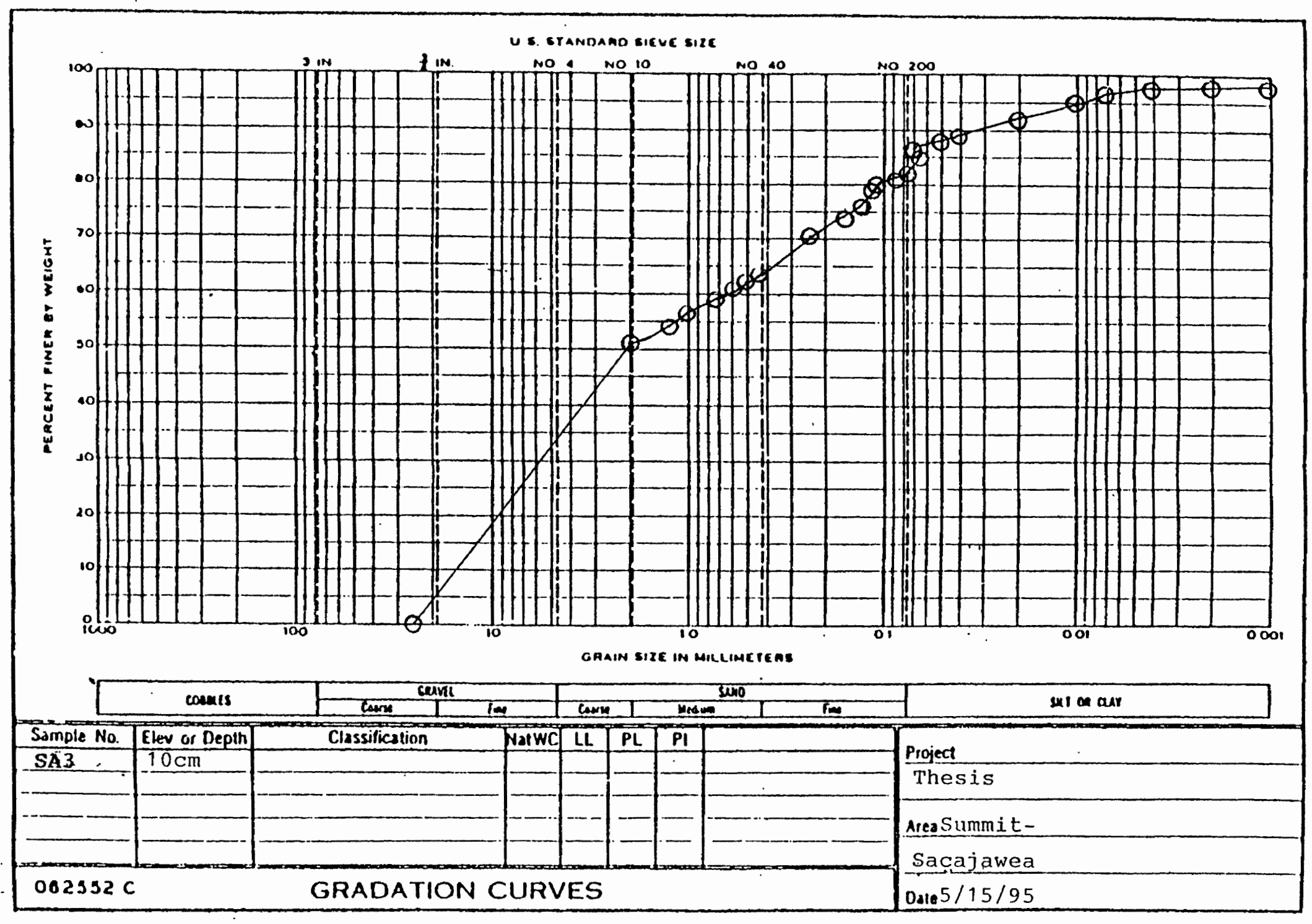


APPENDIX C

SODIUM FLUORIDE (NaF) PH PROCEDURE 


\section{SODIUM FLUORIDE (NaF) PH TEST FOR ALLOPHANE}

The sodium fluoride test looks for high quantities of carbonate, gibbsite, and amorphous aluminum in the soil (Theng 1980). It is especially effective when used to determine high aluminum quantities, thereby establishing a reading for volcanic ash content. According to the soil Taxonomy (Soil Survey Staff 1975: 47), if the soil pH reads over 9.4 after 2 minutes, there is a substantial amount of aluminum present (exchange complex dominated by amorphous material, ECDAM criteria states a reading of 9.2 or greater after 2 minutes).

To test for allophane, use the following procedure:

1. Air dry sample.

2. Weigh $1 \mathrm{gm}$ of air dried soil in $100 \mathrm{ml}$ beaker.

2. mix up the reagent: $1 \mathrm{M}$ NaF solution [1gm molecular weight $=42 \mathrm{~g}$ dissolved in 1 liter $\mathrm{H} 2 \mathrm{O}$ ]

3. Add $50 \mathrm{ml}$ of the NaF stock solution to $1 \mathrm{gm}$ of soil and swirl.

4. Measure $\mathrm{pH}$ after $1,2,3,5,20$, and 60 minutes.

5. Record results and whether they fit Soil Taxonomy criteria ( $\mathrm{ph}>9.4$ in 2 minutes satisfies criteria).

6. Do this for each sample, including the blank. 
APPENDIX D

SILT MINERALOGY PROCEDURE 


\section{SILT MINERALOGY}

To obtain mineralogy readings, the hydrometer column samples from particle size analysis were further settled (using procedure below) to separate the silt from the clay (Chao 1969). The clay particles remained in suspension, for possible clay mineralogy tests in future work. The pure silt sample was dried, then ground to a powder. The very fine silt was put on a plate sample and passed through the radiation diffractometer from a range of 2 to 60 degrees. The fluctuating levels on the curves signify the different quantities of a particular mineral, which was then identified using Chao (1969).

To test for silt mineralogy use the following procedure:

1. Collect silt sample after hydrometer test (particle size analysis).

2. Put silt mixture into $500 \mathrm{ml}$ beaker and shake. Let it settle and after 4 hours remove everything above $5 \mathrm{~cm}$ in the beaker with a pipette, and dispose of it.

3. Add water until the level is $8 \mathrm{~cm}$ above the bottom of the beaker. Mix, and after 4 hours remove the top $5 \mathrm{~cm}$ of liquid and dispose of it.

4. Repeat step 3 until the solution is clear after mixing and letting sit for 4 hours. The remaining silt should be oven-dried and a sample made for $\mathrm{X}$-raying. 
闯

90

80

80

40

30

20

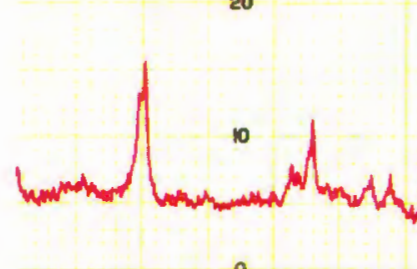

$1 E C 2$

Salinple C. Allen $\frac{\text { BuIK Nate }}{50 / 30 / 95}$

Tube CA.8S Tareet Cu Ka Filter Mow

Soller Silt The ta Time const.__ 1:0 sec

Beam turnel_ Rate meter $5 K$ CPS

Detector slli $0.2^{\circ}$ asin_____ Coarse/fine)

scan speed $2^{\circ}$ [26iminjChart speed $0.5 \mathrm{ln} / \mathrm{min}$
90

$\infty$

20 


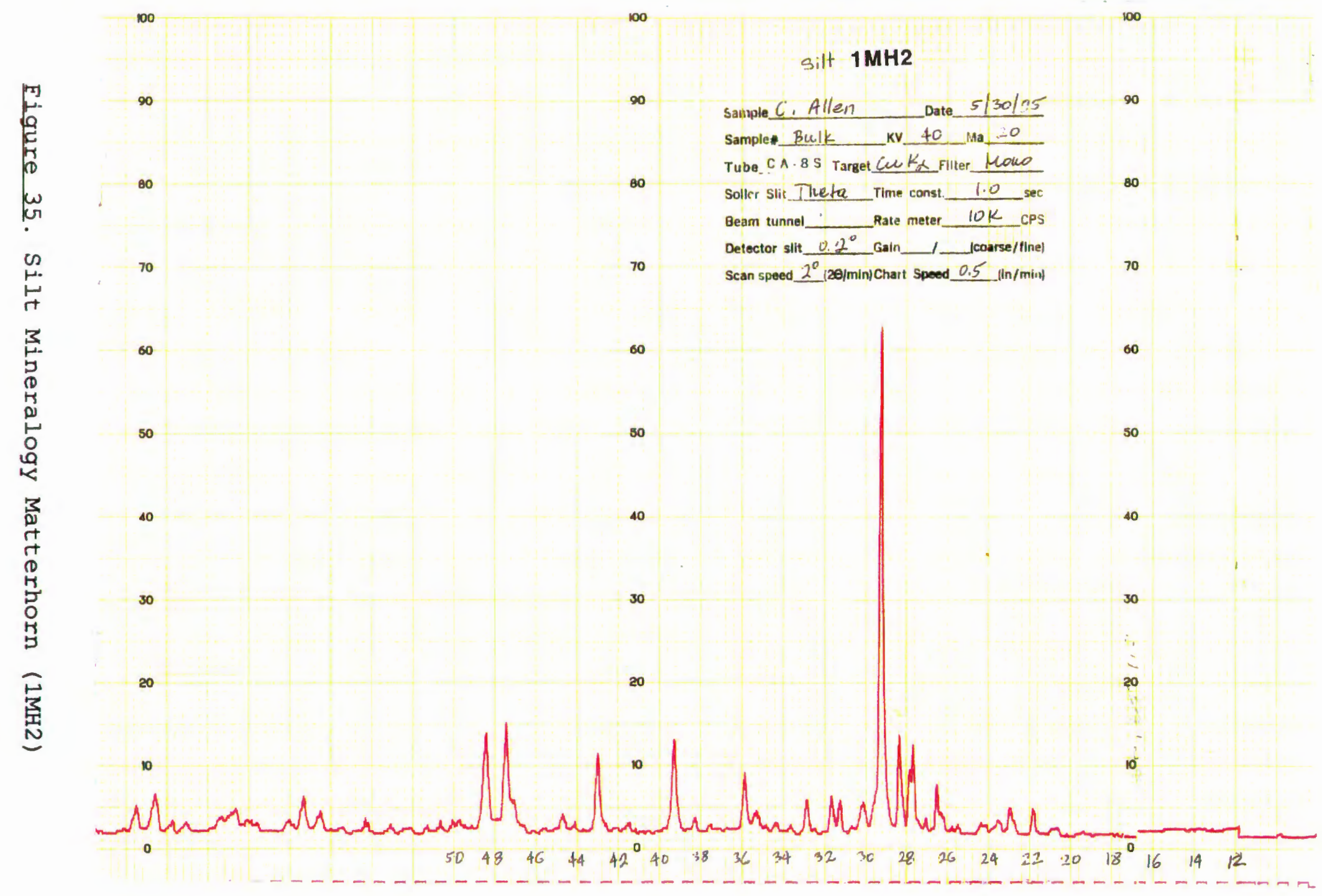

